\title{
DESENVOLVIMENTO DO SISTEMA RADICULAR E DA PARTE AÉREA DO FEIJOEIRO COMUM EM FUNÇÃO DA DISTRIBUIÇÃO E DO TEOR DE FÓSFORO NO SOLO
}

\section{MÍRIAM FERRAZ MOREIRA}

Tese apresentada à Escola Superior de Agricultura

"Luiz de Queiroz", Universidade de São Paulo, para a obtenção do título de Doutor em Agronomia, Área de Concentração: Fitotecnia.

P I R A C I C A B A

Estado de São Paulo - Brasil

Maio - 2004 


\title{
DESENVOLVIMENTO DO SISTEMA RADICULAR E DA PARTE AÉREA DO FEIJOEIRO COMUM EM FUNÇÃO DA DISTRIBUIÇÃO E DO TEOR DE FÓSFORO NO SOLO
}

\section{MÍRIAM FERRAZ MOREIRA}

Engenheiro Agrônomo

\author{
Orientador: Prof. Dr. DURVAL DOURADO NETO \\ Co-orientador: Prof. Dr. RICARDO FERRAZ DE OLIVEIRA
}

\footnotetext{
Tese apresentada à Escola Superior de Agricultura

"Luiz de Queiroz", Universidade de São Paulo, para a obtenção do título de Doutor em Agronomia, Área de Concentração: Fitotecnia.
}

P I R A C I C A B A

Estado de São Paulo - Brasil

Maio - 2004 
Dados Internacionais de Catalogação na Publicação (CIP) DIVISÃO DE BIBLIOTECA E DOCUMENTAÇÃO - ESALQ/USP

Moreira, Miriam Ferraz

Desenvolvimento do sistema radicular e da parte aérea do feijoeiro comum em função da distribuição e do teor de fósforo no solo / Miriam Ferraz Moreira. - Piracicaba, 2004.

135 p. : il.

Tese (doutorado) - - Escola Superior de Agricultura Luiz de Queiroz, 2004. Bibliografia.

1. Desenvolvimento vegetal 2. Feijão 3. Fósforo 4. Nutrição vegetal 5. Química do solo 6 . Sistema radicular I. Título

CDD 635.652 
Aos meus amados pais, FÁBIO e REGINA, irmãs, SÍLVIA, MARÍLIA, LAVÍNIA, sobrinhos, FILIPE e JOÃO, pelo incondicional apoio, e pela forte estrutura familar, da qual me orgulho e me considero abençoada

Aos meus admirados avós:

PAULO, professor universitário, e

SYLVIO, Engenheiro Agrônomo,

que pelo respeito obtido de alunos e pesquisadores, inspiraram-me a escolha da profissão,

\section{DEDICO}

Às minhas queridas tias, que deixaram saudades, RUTE, pelo exemplo da plenitude da palavra professora, TÚIA, por ter, tão docemente, me acolhido em sua casa, no meu primeiro ano em Piracicaba 


\section{AGRADECIMENTOS}

Agradeço à Deus pelas pessoas maravilhosas que colocou no meu caminho.

Ao Prof. Dr. Durval Dourado Neto, meu orientador, pela oportunidade, orientação, apoio, formatação da tese, paciência e exemplo de dedicação, generosidade e humildade.

Ao Prof. Dr. Ricardo Ferraz de Oliveira, meu co-orientador, pelos ensinamentos, oportunidade, paciência e apoio nas mais diversas situações. E, por ter criado e colocado à minha disposição, a excelente infra-estrutura e maravilhoso ambiente de trabalho, do Laboratório de Fisiologia de Plantas Cultivadas sob Condições de Estresse, Departamento de Ciências Biológicas ESALQ/USP, onde realizei a maior parte do meu trabalho.

Ao Prof. Dr. Paulo Augusto Manfron, da Universidade Federal de Santa Maria pelo apoio, pelas valiosas sugestões e pela preciosa dedicação nas correções.

Ao Rafael Vasconcelos Ribeiro, pelas lindas figuras, análise estatística e, principalmente, pela paciência.

Ao CNPq pela bolsa concedida durante o curso.

À Fundação de Amparo a pesquisa do Estado de São Paulo (FAPESP), pela bolsa e reserva técnica que viabilizaram a execução deste trabalho;

Aos professores membros da Comissão de Pós-graduação e funcionários da Seção de Pós-graduação da ESALQ/USP.

Ao Prof. Dr. José Dias Costa, pelo apoio e por ter sido sempre gentil e atencioso.

À Prof. Dra. Marília Contin Ventrella, da Universidade de Viçosa (UFV), por realizar correções, dar brilhantes sugestões na redação, e tão calorosamente, me acolher em sua casa durante o período em que me auxiliou.

Aos professores do Departamento de Produção Vegetal pelos ensinamentos. 
Às secretárias Elisabete Aparecida Sarkis São João, Luciane Aparecida Lopes Toledo e Sílvia Borghesi, por terem ter sido sempre muito atenciosas e prestativas.

Ao Prof. Dr. Antônio Sanchez de Oliveira, por ter me auxiliado com a parte burocrática referente ao meu estágio nos Estados Unidos.

Ao Prof. Dr. Jonathan P. Lynch, pela oportunidade e supervisão durante o período de janeiro à julho de 2003, quando permaneci no Departamento de Horticultura da Universidade Estadual da Pensilvânia (The Penn State University), Estados Unidos; pela disposição de excelente infra-estrutura; e pelos ensinamentos, inclusive os obtidos na sua disciplina de Nutrição Mineral de Plantas.

Ao Neal Barto, pelo companheirismo e medições de respiração radicular.

A todos os membros dos laboratórios dos Dr. Jonathan P Lynch e Dra. Kathellen Brown, especialmente à Melissa Ho, pelos ensinamentos e à Michele Brown, minha "Office mate” pelo ambiente agradável no escritório.

Aos queridos Aleksandar Dozic, Cecília Willianson, Magalhães Miguel, Milica Dozic, Neal Barto, Omer Falik e Renata Monteiro Consoli, pelos auxílios, e, principalmente, pela amizade tão fundamentais durante o período que permaneci nos Estados Unidos.

Aos queridos colegas de laboratório e "agregados" André Venturoso Furlanis, Andréia Camargo de Oliveira; Camila do Prado Cenciani, Dr. Carlos Daniel Giaveno, Dr. Carlos Rodrigues Pereira, Daniela Maia Souza e Dr. Gustavo Maia Souza, Hélio Lins da Silva, Ilana Urbano Bron; Mauro Guida dos Santos, Marcelo Ribeiro Romano, Dra. Michele Narazé Xavier da Costa, Nirlei Aparecida Silva, Oscar Dario Bermudez Zambrano, Paula Carolina de Simoni Cordeiro, Rafael Vasconcelos Ribeiro, Raul Santin, Dr. Ricardo Ferraz de Oliveira, Saulo de Tarso Aidar, Vera Lúcia Ávila, pelo ambiente de trabalho tão amistoso e cooperativo.

À disposição, às sugestões, ao incentivo e ao apoio dos amigos Dr. Carlos Daniel Giaveno, Dr. Carlos Rodrigues Pereira, Dr. Gustavo Maia Souza, Mauro Guida dos Santos e Rafael Vasconcelos Ribeiro.

Ao Dr. Carlos Daniel Giaveno, pelo auxílio na execução do experimento em solução nutritiva. 
À excelente aluna de iniciação científica Camila do Prado Cenciani, pelo auxílio nas medições do último experimento e ensinamentos para a utilização programa SANEST.

Aos funcionários do Horto do Departamento de Ciências Biológicas da ESALQ/USP, José Francisco Rodrigues (Pequeno) e Francisco Xavier Vitti (Tirolês) pelo auxílio recebido nos experimento na casa-de-vegetação.

A Luciana de Campos Silva, por manter o ambiente limpo e pela alegria contagiante.

Ao Dr. Sérgio Carbonell, do Instituto Agronômico de Campinas, pelas sementes cedidas.

Ao Departamento de Biologia da Universidade Federal de Viçosa (UFV) pelo fornecimento do corante vermelho neutro.

Àos funcionários da Bibiloteca (ESALQ/USP), em especial, à bibliotecária Eliana Garcia por ter sido sempre atenciosa e eficiente nas correções.

Ao Técnico Especializado de Nível Superior do Departamento de Produção Vegetal (ESALQ/USP), Dr. Edson Roberto Teramoto, pelo importante apoio e amizade.

Ao Departamento de Genética da (ESALQ/USP), pela coleta da terra em sua Estação Experimental para a realização de experimentos em casa-de-vegetação.

À minha querida irmã Marília, por ter resolvido todas as questões em Campinas durante a minha ausência.

Aos meus cunhados Pedro e Wilsom, pelos meus preciosos sobrinhos, Filipe e João, minha constante fonte alegria.

Á Margarete Klein, pela amizade e cuidados tomados durante a minha estadia nos EUA.

Aos dez Engenheiros Agrônomos, por formação, e aos outros três, por vocação, que fizeram do amor à agricultura, uma característica da minha família. Em especial, ao meu tio Célio, maravilhoso anfitrião, que me apoiou durante toda a minha estadia em Piracicaba. 
À toda minha família, especialmente meu tio Laerte, meus primos Zize, Paulinho e Luciana, meus tios Geraldo e Rachel, por terem compreendido minha ausência física em um momento difícil.

Aos amigos do CEBTEC, em especial ao Antônio Amaral, pelo apoio nas mais diversas situações.

Ao Cássio Rizzardo, Dra Denise Návia, e Maria Stella Ferraz pelo incentivo e amizade.

Aos colegas Reinaldo Antônio Garcia Bonecarrère e Thomas Newton Martin pela grande ajuda na conferência final da Tese.

Aos funcionários da Copiado Luiz de Queiroz, pela atenção e capricho.

Ao meu querido primo e afilhado Thiago Camunhas Ferraz, pelo grande orgulho, que tenho, de sua força de vontade e perseverança. 


\section{SUMÁRIO}

Página

LISTA DE FIGURAS ............................................................................

LISTA DE TABELAS ........................................................................... xvii

LISTA DE SÍMBOLOS .............................................................................. xix

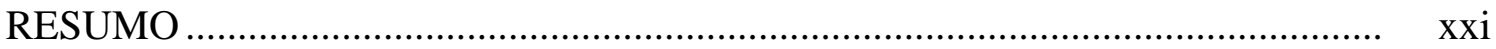

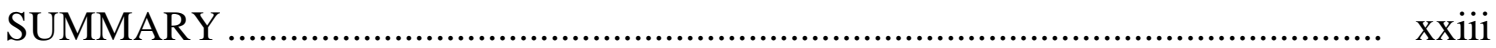

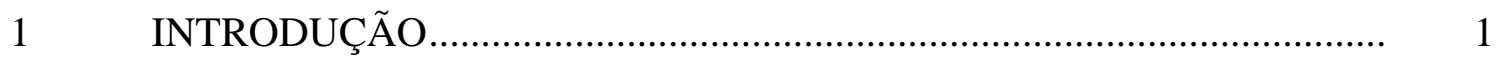

2 REVISÃO DE LITERATURA ............................................................. 3

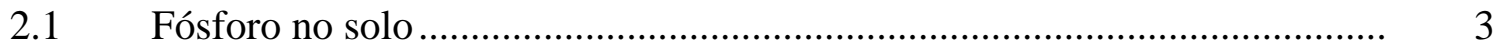

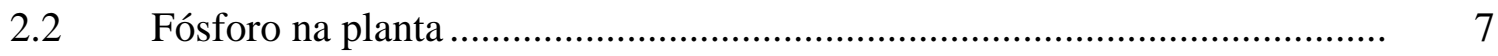

2.3 Funções do fósforo na planta.................................................................... 8

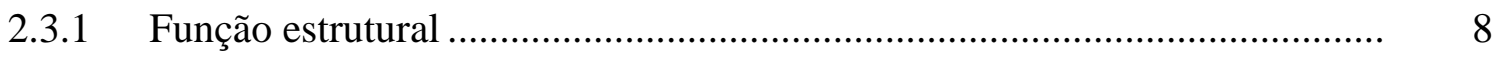

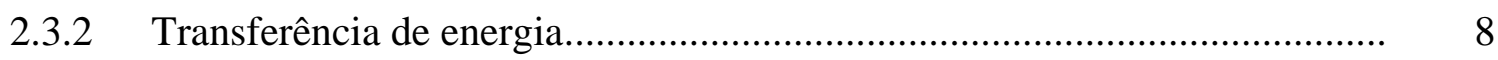

2.3.3 Compartimentalização e papel regulador do fosfato inorgânico ................... 9

2.3.4 Função na fotossíntese ........................................................................... 10

2.3.5 Fornecimento de p e crescimento de plantas ........................................... 10

2.3.6 Fotossíntese e deficiência de fósforo....................................................... 19

2.3.7 Deficiência de fósforo em feijoeiro comum ............................................... 22

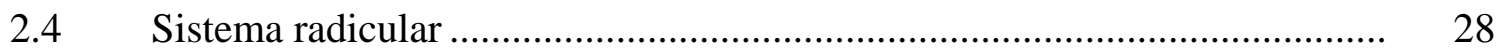

2.4.1 Arquitetura do sistema radicular ........................................................ 28

2.4.2 Plasticidade do sistema radicular.......................................................... 31

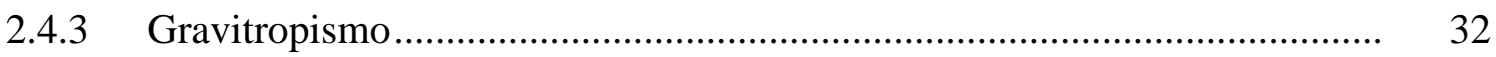

2.4.4 Custo metabólico do sistema radicular e deficiência de fósforo .................. 35

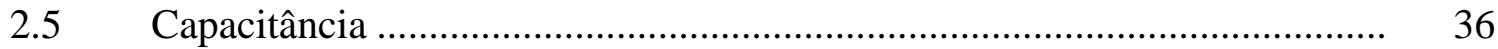


3 MATERIAL E MÉTODOS ............................................................ 38

$3.1 \quad$ Material vegetal ............................................................................ 38

3.2 Local de instalação e condução dos experimentos ......................................... 38

3.3 Capacitância e atributos da planta ................................................................ 40

3.4 Experimento I: calibração do medidor bk precision 810 b para determinação de capacitância de plantas de feijão (feijoeiro comum) em solução nutritiva

3.5 Experimento II: efeito do fósforo no desenvolvimento do sistema radicular e da parte aérea do feijoeiro comum e calibração para determinação de capacitância em substrato sólido.....

3.6 Experimento III: seleção entre seis genótipos para o enraizamento adventício do feijoeiro comum em diferentes teores de fósforo no substrato (areia)

3.7 Experimento IV: seleção entre 9 genótipos para o enraizamento adventício do feijoeiro comum em diferentes teores de fósforo no substrato (areia e vermiculita)

3.8 Experimento V: efeito do teor e da distribuição de fósforo no substrato e de cinco genótipos no desenvolvimento do feijoeiro comum

3.9 Experimento VI: efeito do fósforo estratificado no substrato no desenvolvimento do feijoeiro comum .......................................................... 54

4 RESULTADOS E DISCUSSÃO

4.1 Experimento I: calibração do medidor bk precision 810 b para determinação de capacitância de plantas de feijão (feijoeiro comum) em solução nutritiva

4.2 Experimento II: efeito do fósforo no desenvolvimento do sistema radicular e da parte aérea do feijoeiro comum e calibração para determinação de capacitância em substrato sólido

4.3 Experimento III: seleção entre seis genótipos para o enraizamento adventício do feijoeiro comum em diferentes teores de fósforo no substrato (areia) 
4.4 Experimento IV: seleção entre 9 genótipos para o enraizamento adventício do feijoeiro comum em diferentes teores de fósforo no substrato (areia e vermiculita) ........................................................... 66

4.5 Experimento $\mathrm{V}$ : efeito do teor e da distribuição de fósforo no substrato e de cinco genótipos no desenvolvimento do feijoeiro comum ......................

4.6 Experimento VI: efeito do fósforo estratificado no substrato no desenvolvimento do feijoeiro comum ................................................ 90

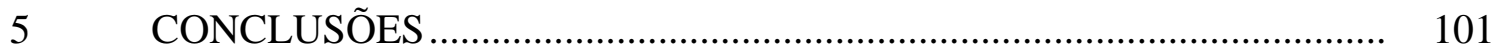

REFERÊNCIAS BIBLIOGRÁFICAS ........................................................ 102

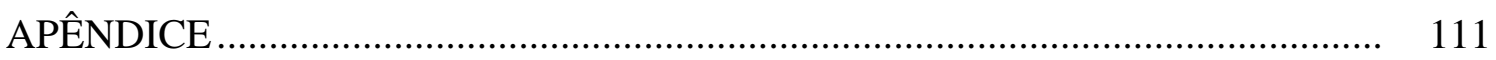




\section{LISTA DE FIGURAS}

Página

1 Regulação da arquitetura do sistema radicular em função do teor de fósforo no solo. Baixo teor de fósforo (a) estimula a produção de raiz adventícia, (b) aumenta raízes basais na superfície, (c) aumenta a dispersão das raízes laterais e (d) aumenta a densidade e elongação dos pêlos radiculares, que favorece absorção de fósforo (Adaptado de Lynch \& Brown, 2001)

2 Ângulo de crescimento da raiz basal dos genótipos G2333 e G19839 em resposta à baixa disponibilidade de fósforo no solo.

3 Arquitetura radicular de dois genótipos de feijoeiro 26

4 Efeito da baixa disponibilidade de P sobre a formação de raízes adventícias ..... 27

5 Variação do ângulo da raiz basal do sistema radicular do feijoeiro comum........ 30

6 Representação esquemática do medidor portátil de capacitância BK Precision.. 40

7 Determinação de capacitância com uso do medidor BK Precision 810 B .......... 42

$8 \quad$ Feijoeiro comum em diferentes doses de P................................................ 46

$9 \quad$ Sistema radicular do feijoeiro comum em diferentes doses de P ...................... 46

10 Determinação da área radicular do feijoeiro comum ...................................... 47

11 Determinação da respiração radicular ............................................................. 53

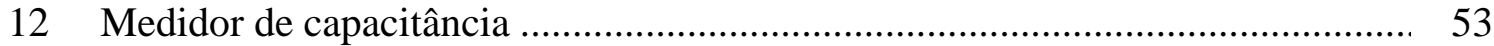

13 Relação entre capacitância e a fitomassa fresca radicular das plantas desenvolvidas em condições de solução nutritiva........................................... 58

14 Correlação entre valores capacitância e de fitomassa fresca de plantas de feijão providas de $\mathrm{P}$

15 Correlação entre valores de capacitância e fitomassa fresca de plantas de feijão desprovido de $\mathrm{P}$ 
16 Correlação entre valores de capacitância $(200 \mathrm{nF})$ e fitomassa seca de parte aérea (FSa, g.planta ${ }^{-1}$ ) (A), fitomassa seca radicular (FSr, g.planta $\left.{ }^{-1}\right)(B)$, área do sistema radicular $\left(\mathrm{Ar}, \mathrm{mm}^{2}\right.$ ) (C) e comprimento radicular (C, mm) (D) de plantas de feijão, variedade cultivada Pérola, desenvolvidas com e sem adição de $\mathrm{P}$ ao substrato

17 Correlação entre valores de capacitância (200nF) e fitomassa seca aérea $\left(\mathrm{FSa}\right.$, g.planta $\left.{ }^{-1}\right)(\mathrm{A})$, fitomassa seca radicular (FSr, g.planta $\left.{ }^{-1}\right)(\mathrm{B})$, área do sistema radicular $\left(\mathrm{Ar}, \mathrm{mm}^{2}\right)(\mathrm{C})$ e comprimento radicular $(\mathrm{C}, \mathrm{mm})(\mathrm{D}) \mathrm{de}$ plantas de feijão, variedade cultivada Pérola, desenvolvidas com adição de $\mathrm{P}$ ao substrato.

18 Correlação entre valores de capacitância (200nF) e fitomassa seca de parte aérea (FSa, g.planta $\left.{ }^{-1}\right)(\mathrm{A})$, fitomassa seca radicular (FSr, g.planta $\left.{ }^{-1}\right)(\mathrm{B})$, área do sistema radicular ( $\mathrm{Ar}, \mathrm{mm}^{2}$ ) (C) e comprimento radicular (C, mm) (D) de plantas de feijão, variedade cultivada Pérola, desenvolvidas com adição de P ao substrato.

19 Correlação entre valores de capacitância (200nF) e fitomassa seca total (FST, g.planta ${ }^{-1}$ ) no tratamento sem P (SP) (A), com P (CP) (B) e com (CP) e sem (SP) P adicionado ao substrato (C) de plantas de feijão (variedade cultivada Pérola)

20 Fitomassa seca relativa de raízes na camada superficial $(0-6 \mathrm{~cm})$ (FSRrs, \%) e fitomassa seca do sistema radicular (FSr, g.planta ${ }^{-1}$ ), de nove genótipos de feijoeiro comum, aos 21 e 36 dias após emergência, sob alta (Da) e baixa (Db) dose de $\mathrm{P}$

21 Comprimento (Cra, mm) e número de raízes adventícias (Nra) de nove genótipos (G6, G11, G17, G21, G23, G31, G52, G57, G61, G72 e GBR) de feijoeiro, aos 21 e 36 dias após emergência, sob alta (Da) e baixa (Db) dose de $\mathrm{P}$

22 Fitomassa seca de raízes adventícias (FSRra, \%) (genótipos G6 - A, G11 - B, G21 - C - e G57 - D) sob dose alta (Da) e baixa (Db) de P no substrato, aos 14, 21 e 28 dias após a emergência 
23 Fitomassa seca total (FST, g.planta ${ }^{-1}$ ) (A) , de parte aérea (FSa, g.planta ${ }^{-1}$ ) (B) e radicular (FSr, g.planta ${ }^{-1}$ ) de plantas de feijão (genótipos G6, G11, G21 e G57) aos 28 dias após a emergência

24 Fitomassa seca relativa do sistema radicular (FSRr, \%) dos genótipos G6 (A), G11 (B), G21 (C) e G57 (D) de feijoeiro submetidas a dose alta (Da) e baixa (Db) de P no substrato, aos 14, 21 e 28 dias após a emergência

25 Relação entre raiz e parte aérea (Rrpa) dos genótipos G6, G11, G21 e G57 aos 28 dias após a emergência

26 Comprimento radicular ( $\mathrm{Cr}, \mathrm{cm})(\mathrm{A})$, comprimento radicular específico (Cre, $\mathrm{cm} \cdot \mathrm{g}^{-1}$ ) (B) e fitomassa seca relativa de raízes (CRr, \%) (C) de quatro genótipos de feijoeiro, submetidas a dose alta (Da) e baixa (Db) de $\mathrm{P}$ no substrato, aos 28 dias após a emergência

27 Fitomassa seca de raízes adventícias (FSRra, \%) em relação ao valor total de fitomassa de plantas de diferentes genótipos (feijoeiro) submetidas a dose alta (Da) e baixa (Db) de P, aos 14, 21 e 28 dias após a emergência.

28 Número (Nra) e comprimento (Cra, mm) de raízes adventícias de quatro genótipos (G6, G11, G21 e G57) de feijoeiro comum, submetidos à dose alta (Da) e baixa (Db) de P no substrato, aos 28 dias após a emergência.

29 Taxa de respiração radicular $\left(\mathrm{TRr}, \mu \mathrm{mol} \cdot \mathrm{min}^{-1} \cdot \mathrm{g}^{-1}\right.$ de $\left.\mathrm{CO}_{2}\right)$ de diferentes genótipos de feijoeiro: G6 (A), G11 (B), G21 (C) e G57 (D), submetidos à dose alta ( $\mathrm{Da})$ e baixa $(\mathrm{Db})$ de $\mathrm{P}$ no substrato, aos 14 e 28 dias após a emergência

30 Taxa de respiração radicular (TRr, $\mu$ mol. $\mathrm{min}^{-1} \cdot \mathrm{m}^{-1}$ de $\mathrm{CO}_{2}$ ) de diferentes genótipos de feijoeiro: G6 (A), G11 (B), G21 (C) e G57 (D), submetidas à dose alta $(\mathrm{Da})$ e baixa $(\mathrm{Db})$ dose de $\mathrm{P}$, determinadas aos 14 e 28 dias após a emergência 
31 Valores médios de capacitância (20nF) de plantas de feijão (G6, G11, G21 e G57), aos 28 dias após a emergência

33 Correlação entre capacitância e fitomassa seca do sistema radicular (FSr, g.planta $^{-1}$ ) (A), total (FST, g.planta ${ }^{-1}$ ) (B) e da parte aérea (FSa, g.planta ${ }^{-1}$ ) (C) e comprimento do sistema radicular (Cr, mm) (D) de plantas de feijão do genótipo G6, aos 14, 21 e 28 dias após a emergência.

34 Correlação entre capacitância e fitomassa seca do sistema radicular (FSr, g.planta $^{-1}$ ) (A), total (FST, g.planta ${ }^{-1}$ ) (B) e da parte aérea (FSa, g.planta ${ }^{-1}$ ) (C) e comprimento do sistema radicular (Cr, mm) (D) de plantas de feijão do genótipo G11, aos 14, 21 e 28 dias após a emergência

35 Correlação entre capacitância e fitomassa seca do sistema radicular $\left(\mathrm{FSr}\right.$, g.planta $\left.{ }^{-1}\right)(\mathrm{A})$, total $\left(\mathrm{FST}\right.$, g.planta $\left.^{-1}\right)(\mathrm{B})$ e da parte aérea (FSa, g.planta ${ }^{-1}$ ) (C) e comprimento do sistema radicular (Cr, mm) (D) de plantas de feijão do genótipo G21, aos 14, 21 e 28 dias após a emergência.

36 Correlação entre capacitância e fitomassa seca do sistema radicular (FSr, g.planta $^{-1}$ ) (A), total (FST, g.planta ${ }^{-1}$ ) (B) e da parte aérea (FSa, g.planta ${ }^{-1}$ ) (C) e comprimento do sistema radicular (Cr, mm) (D) de plantas de feijão do genótipo G57, aos 14, 21 e 28 dias após a emergência

37 Correlação entre capacitância e respiração do sistema radicular, de plantas de feijão, do genótipo G6, aos 14 e 28 dias após a emergência.

38 Correlação entre capacitância e respiração do sistema radicular, de plantas de feijão, do genótipo G11, aos 14 e 28 dias após a emergência.....

39 Correlação entre capacitância e respiração do sistema radicular, de plantas de feijão, do genótipo G21, aos 14 e 28 dias após a emergência.

40 Correlação entre capacitância e respiração do sistema radicular, de plantas de feijão, do genótipo G57, aos 14 e 28 dias após a emergência. 
41 Correlação entre capacitância e fitomassa seca radicular (FSr, g.planta ${ }^{-1}$ ) (A), fitomassa seca total (FST, g.planta ${ }^{-1}$ ) (B), fitomassa seca de parte aérea (FSa, g.planta $^{-1}$ ) (C) e comprimento do sistema radicular(Cr, mm) (D) dos genótipos de feijoeiro comum (G6, G11, G21 e G57), aos 14, 21 e 28 dias após emergência, sob dose alta (Da) e baixa (Db) de P

42 Plantas de feijão desenvolvidas em diferentes tratamentos com relação ao posicionamento de $\mathrm{P}$ no vaso: (A) P distribuído unifomemente no vaso (CP), (B) P na camada de 0-5 cm (S), (C) P na camada de 0-5 cm ditribuído em uma faixa de $10 \mathrm{~cm}$ de largura (SF), (D) P distribuído em faixa na camada de 10-15 cm de profundidade (SSF), (E) P uniformente distribuído na camada de 10-15 cm (SS), e (F) sem adição de P (SP)

43 Comprimento do sistema radicular ( $\mathrm{Cr}, \mathrm{mm})(\mathrm{A})$, número de raízes adventícias (Nra) (B), comprimento relativo de raízes na camada de 0-15 cm de profundidade (CRr, \%) (C), área do sistema radicular ( $\mathrm{Ar}, \mathrm{cm}^{2}$ ) (D) de feijoeiro comum, variedade cultivada Pérola, com P (CP), sem P (SP), P localizado na camada de 10-15 cm de profundidade (SS), P localizado em faixa, na camada de 10-15 cm de profundidade (SSF), P localizado na camada de 0-5 cm de profundidade (S) e P localizado, em faixa, na camada de $0-5 \mathrm{~cm}$ de profundidade (SF)

44 Fitomassa seca radicular (FSr, g.planta ${ }^{-1}$ ) (A) e de parte aérea (FSa, g.planta ${ }^{-1}$ ) (B) e relação entre raiz e parte aérea de feijoeiro comum (Rrpa) (C), variedade cultivada Pérola, sem P (CP) e com P (SP) localizado na camada de 10-15 cm de profundidade (SS), em faixa, na camada de 10-15 cm de profundidade (SSF), na superfície (S) e na superfície em faixa (SF)........

45 Número de folhas compostas (Nf) e área radicular (Ar, cm².planta ${ }^{-1}$ ) de feijoeiro comum, variedade cultivada Pérola, sem P (CP) e com P (SP) localizado na camada de 10-15 cm de profundidade (SS), em faixa, na camada de 10-15 cm de profundidade (SSF), na superfície (S) e na superfície em faixa (SF) 
46 Número de grãos por planta (Ng) (A), fitomassa seca dos grãos (FSg, g.planta $^{-1}$ ) (B), duração do ciclo (dias) (C) e número de vagens por planta (Nv) (D) do feijoeiro comum, variedade cultivada Pérola, com P (CP) e sem P (SP) localizado na camada de 10 a $15 \mathrm{~cm}$ de profundidade (SS), em faixa, na camada de 10 a $15 \mathrm{~cm}$ de profundidade (SSF), na superfície (S) e na superfície em faixa (SF) 


\section{LISTA DE TABELAS}

Página

1 Escala fenológica referente ao feijoeiro comum (Gepts \& Fernández, 1982; Dourado Neto \& Fancelli, 2000)...................................................... 24

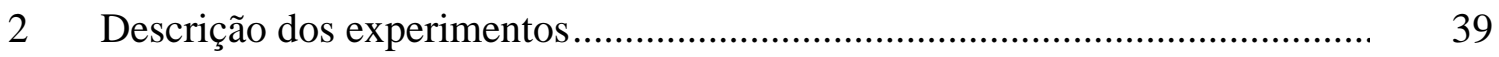

3 Análise química de solo: $\mathrm{pH}$ em $\mathrm{CaCl}_{2}(\mathrm{pH})$, teor de matéria orgânica $\left(\mathrm{MO}, \mathrm{g} \cdot \mathrm{dm}^{-3}\right)$, fósforo $\left(\mathrm{P}, \mathrm{mg} \cdot \mathrm{dm}^{-3}\right)$, enxofre $\left(\mathrm{S}, \mathrm{mg} \cdot \mathrm{dm}^{-3}\right)$, potássio (K, $\left.\mathrm{mmol}_{\mathrm{c} \cdot} \cdot \mathrm{dm}^{-3}\right)$, Ca $\left(\mathrm{Ca}, \mathrm{mmol}_{\mathrm{C}} \cdot \mathrm{dm}^{-3}\right)$, magnésio $\left(\mathrm{Mg}, \mathrm{mmol}_{\mathrm{C}} \cdot \mathrm{dm}^{-3}\right)$, alumínio $\left(\mathrm{Al}, \mathrm{mmol}_{\mathrm{C}} \cdot \mathrm{dm}^{-3}\right)$, hidrogênio e alumínio $\left(\mathrm{H}+\mathrm{Al}, \mathrm{mmol}_{\mathrm{c} \cdot} \cdot \mathrm{dm}^{-3}\right)$, soma de bases $\left(\mathrm{SB}, \mathrm{mmol}_{\mathrm{C}} \cdot \mathrm{dm}^{-3}\right)$, capacidade de troca catiônica $\left(\mathrm{T}, \mathrm{mmol}_{\mathrm{c}} \cdot \mathrm{dm}^{-3}\right)$, saturação de bases $(\mathrm{V}, \%)$, saturação por alumínio (m, \%).............................

4 Análise de química do solo: micronutrientes $\left(\mathrm{mg}^{\mathrm{d}} \mathrm{dm}^{-3}\right)$ 43

5 Análise granulométrica do solo.

6 Composição da solução nutritiva. Os tratamentos dose alta (Da) e baixa (Db) diferem na quantidade de solução 3. Utilizou-se em Da 1 mM e em Db 0,001 mM na água de irrigação (Lynch et al., 1992)

7 Resposta de diferentes genótipos de feijoeiro comum à dose alta (Da) e à dose baixa (Db) de $\mathrm{P}$, em que Nra se refere ao número de raízes adventícias, e FSrs, FSrp e FSra à fitomassa seca (g.planta ${ }^{-1}$ ) das raízes superficiais, das raízes profundas e das raízes adventícias, respectivamente .. 
8 Coeficientes de correlação entre médias de quatro repetições de valores de capacitância (20 nF) e fitomassa seca radicular (FSr, g.planta ${ }^{-1}$ ), fitomassa seca de parte aérea (FSa, g.planta ${ }^{-1}$ ), fitomassa seca total (FST, g.planta ${ }^{-1}$ ), comprimento radicular $(\mathrm{Cr}, \mathrm{cm})$ e respiração do sistema radicular $\left(\mu \mathrm{mol} \cdot \mathrm{min}^{-1} \cdot \mathrm{g}^{-1}\right.$ de $\mathrm{CO}_{2}$ ), aos 14, 21 e 28 dias de quatro genótipos de feijoeiro

9 Resultado da análise do tecido da parte aérea do feijeiro, submetidos aos seis tratamentos, em que $\mathrm{CP}$ se refere ao tratamento em que o $\mathrm{P}$ foi distribuído uniformemente, SP ao tratamento sem adição de P, SS ao tratamento em que o $\mathrm{P}$ foi distribuído unifomemente na camada de 10-15 cm de profundidade, SSF ao tratamento em que o P foi distribuído em uma faixa de $10 \mathrm{~cm}$ de largura na camada de 10-15 cm de profundidade, S ao tratamento em que o $\mathrm{P}$ foi localizado na camada de $0-5 \mathrm{~cm}$ de profundidade, e SF ao tratamento em que o $\mathrm{P}$ foi distribuído em uma faixa de $10 \mathrm{~cm}$ de largura na camada de $0-5 \mathrm{~cm}$ de profundidade

10 Teor de $\mathrm{P}$ no tecido da parte aérea de plantas de feijão submetidas aos diferentes tratamentos 


\section{LISTA DE SÍMBOLOS}

-P Com baixo teor de fósforo no solo

$+\mathrm{P} \quad$ Com alto teor de fósforo no solo

Al-P Fósforo sólido tamponado

Ar área radicular $\left(\mathrm{cm}^{2} \cdot\right.$ planta $\left.^{-1}\right)$

CP Tratamento com adição de $\mathrm{P}$ ao substrato

$\mathrm{Cr} \quad$ Comprimento do sistema radicular (mm)

CRr (0-15) Comprimento relativo de raízes, o qual é calculado pela relação entre o comprimento de raiz na camada de 0-15 $\mathrm{cm}$ de profundidade e o comprimento de raiz na camada de 0-40 $\mathrm{cm}$ de profundidade (\%). Mensuração efetuada no experimento VI.

$\mathrm{Da} \quad$ Dose alta de fósforo

$D A E \quad$ Dias após a emergência

$D b \quad$ Dose baixa de fósforo

FSa Fitomassa seca da parte aérea (g.planta ${ }^{-1}$ )

FSr Fitomassa seca radicular (g.planta ${ }^{-1}$ )

$F S R_{i} \quad$ Fitomassa seca de raiz (g.m ${ }^{-2}$ ) (valor medido) no i-ésimo dia de amostragem

FSrp Fitomassa seca das raízes profundas (g.planta ${ }^{-1}$ )

FSRr Fitomassa seca relativa radicular (g.planta ${ }^{-1}$ )

FSRra Fitomassa seca relativa das raízes adventícias

FSRrs Fitomassa seca relativa das raízes superficiais

FST Fitomassa seca total (g.planta ${ }^{-1}$ )

GBR Variedade cultivada brasileira Pérola

$\mathrm{Nf} \quad$ Número de folhas compostas

Nra Número de raízes adventícias 
r/a Relação entre raiz e parte aérea de feijoeiro comum

S P localizado na camada de $0-5 \mathrm{~cm}$ do vaso

SF P localizado em faixa na camada de $0-5 \mathrm{~cm}$ do vaso

SP Tratamento sem adição de $\mathrm{P}$ ao substrato

SS P localizado na camada de $10-15 \mathrm{~cm}$ de profundidade do vaso

SSF P localizado em faixa na camada de $10-15 \mathrm{~cm}$ de profundidade do vaso

TR Respiração do sistema radicular ( $\mu$ mol.planta ${ }^{-1} \cdot \min ^{-1}$ de $\mathrm{CO}_{2}$ )

$\mathrm{TRr}$ Taxa de respiração radicular $\left(\mu \mathrm{mol} \cdot \mathrm{min}^{-1} \cdot \mathrm{m}^{-1}\right.$ de $\left.\mathrm{CO}_{2}\right)$

$\mathrm{TRr}$ Taxa de respiração radicular $\left(\mu \mathrm{mol} \cdot \mathrm{min}^{-1} \cdot \mathrm{g}^{-1}\right.$ de $\left.\mathrm{CO}_{2}\right)$ 


\title{
DESENVOLVIMENTO DO SISTEMA RADICULAR E DA PARTE AÉREA DO FEIJOEIRO COMUM EM FUNÇÃO DA DISTRIBUIÇÃO E DO TEOR DE FÓSFORO NO SOLO
}

\author{
Autor: MÍRIAM FERRAZ MOREIRA \\ Orientador: Prof. Dr. DURVAL DOURADO NETO \\ Co-orientador: Prof. Dr. RICARDO FERRAZ DE OLIVEIRA
}

\section{RESUMO}

O sistema radicular é indispensável para a obtenção de água e nutrientes do solo, síntese de reguladores de crescimento, e para o armazenamento de carboidratos. Embora seja indiscutível sua importância, esse órgão tem sido pouco estudado em relação a parte área. Provavelmente, em função da dificuldade de seu estudo, tendo em vista que seu desenvolvimento ocorre no solo, o que dificulta observações diretas. Consideramos de suma importância o desenvolvimento de métodos mais práticos, mais baratos, e que possibilitem avaliações rápidas, não destrutivas do sistema radicular. O conhecimento de uma estreita relação entre fitomassa fresca do sistema radicular e valor de capacitância, é antigo, mas na prática, é pouco empregado. Através do uso de um medidor manual de capacitância, visamos relacionar valores de capacitância com diversos parâmetros, tais como fitomassa seca, comprimento, área e respiração do sistema radicular de plantas do feijoeiro comum (Phaseolus vulgaris L.). Uma vez estabelecidas essas relações, é possível realizar medições com o capacitor para avaliar o desenvolvimento radicular, sob diferentes condições de disponibilidade de fósforo, de uma maneira rápida, prática e não destrutiva. A deficiência de fósforo, em solos tropicais e, subtropicais tem limitado a produção de muitas culturas, inclusive a do feijoeiro, uma das principais fontes de proteínas na dieta de países localizados nessas regiões. Estudos anteriores mostram uma ampla variação com relação à eficiência no uso do elemento fósforo no germoplasma do 
feijoeiro comum, viabilizando adaptação às condições de baixa disponibilidade deste elemento no solo. Devido sua baixa mobilidade do no solo, genótipos que apresentem plasticidade do sistema radicular, com relação a esse elemento, são considerados mais eficientes. Para verificar a eficiência do sistema radicular do feijoeiro comum, foram realizados estudos com o fósforo aplicado de forma desuniforme ao substrato, simulando as condições normalmente encontradas no campo. Supõe-se que existam diferentes mecanismos que conferem maior aproveitamento do fósforo pela planta, sendo muitos destes relacionados ao sistema radicular. Para elucidar essa questão, foram avaliados parâmetros tais como, o posicionamento das raízes ao longo do perfil, o comprimento, a área, a taxa de respiração e a fitomassa seca do sistema radicular. Foi dada especial atenção a formação de raízes adventícias, em diferentes níveis de fósforo, por essas se desenvolverem preferencialmente nas camadas superficiais do solo, onde segundo diversos autores, é o local de maior disponibilidade deste elemento. Além disto, foram avaliados os efeitos do posicionamento do $\mathrm{P}$ no substrato, sobre a parte aérea e sobre a produtividade. O uso da capacitância é uma opção metodológica para: (i) aferir o crescimento de plantas de feijão em termos de fitomassa seca total, e (ii) avaliar a parte funcional do sistema radicular. Em condições ótimas de água e fertilidade do solo, a distribuição de fósforo uniformemente na camada superficial ( 0 a $5 \mathrm{~cm}$ de profundidade) proporciona o aumento dos componentes de produção. O acúmulo e a partição de fitomassa seca em plantas de feijão são condicionados pela disponibilidade (quantidade e posicionamento) de fósforo no solo. 


\section{EFFECT OF PHOSFORUS LEVEL, AND ITS POSITION IN THE SOIL, ON THE COMMOM BEAN SHOOT AND ROOT SYSTEM DEVELOPMENT}

Author: MÍRIAM FERRAZ MOREIRA

Adviser: Prof. Dr. DURVAL DOURADO NETO

Co-adviser: Prof. Dr. RICARDO FERRAZ DE OLIVEIRA

\section{SUMMARY}

The root system is essential to water and nutrient acquisition, hormone synthesis and carbohydrate storage. Although the knowledge about its importance, there are much less studies with this organ, than with the shoots. Probably, due to the difficulties in its study, since it develops in the soil, making directs observations harder. The stabeleshiment of cheap, practical, fast and non-destructive methods to evaluate the root system development would be very useful. Despite the observation of a close relationship between fresh matter and capacitance is not new, there are not many studies with it. The use of a portable capacitance meter to relate capacitance values with different root system parameters, such as dry weight, length, area and respiration, would provide the fast one, and non-destructive evaluation, under different growing conditions, such as different phosphorus levels in the soil. The lack of phosphorus in tropical and sub-tropical soils has limited many crops yield, as common beans, one of the main protein sources of these region countries. Previous studies had shown a wise genetic variation on phosphorus efficiency in common bean germoplasm, which allows the adaptation to low phosphorus condition. Since P presents low mobilization in the soil, genotypes with root plasticity are considered efficient. This study includes experiments where the phosphorus was placed not uniformly in the substrate, simulating the field natural conditions, to verify the common beans root system response. Different mechanism that confers better plants $\mathrm{P}$ use is known, and most of them, are related to the 
root system. Some root parameters such as root position along the profile, root length, root area, root respiration and root dry weight were evaluated to clarify this question. Special focus were given to adventitious root formation under different phosphorus levels, since they grow in shallower soil layer, where according to several author is where there is higher phosphorus availability. Furthermore, the effect of the P position on the shoot and yield were evaluated. The capacitance can be used as an alternative method to evaluate: (i) the bean plants growth, as total dry weight and, (ii) the functional root portion. When water and nutrients are in optimal level, the phosphorus distribution on the top soil layer ( 0 to $5 \mathrm{~cm}$ ), results in the yield component increase. The available phosphorus position in the soil, determines the accumulation and distribution pattern of the dry matter. 


\section{INTRODUÇÃO}

Os estudos na área de Nutrição Mineral de Plantas, têm dado maior importância a fatores relacionados com a arquitetura do sistema radicular (configuração espacial que o sistema radicular adquire para exploração do substrato). O volume do substrato ocupado pelo sistema radicular determina a habilidade da planta para exploração de água e nutrientes. O solo apresenta variável distribuição de nutrientes, especialmente fósforo, além de um gradiente de temperatura, teor de oxigênio, disponibilidade de água, $\mathrm{pH}$ e densidade, que podem ocorrer em escala de centímetros com relação à profundidade do solo.

Como a distribuição natural de nutrientes em solos é heterogênea no espaço e no tempo, nutrientes de baixa mobilidade, como o P, freqüentemente têm sua distribuição estratificada, com elevada concentração nas camadas superiores do solo, em associação com a matéria orgânica ou pela formação de compostos parcialmente solúveis como AlP e Ca-P.

O feijão é uma importante fonte de proteínas na dieta alimentar e constitui o principal alimento em regiões tropicais e subtropicais (FAO, 1991). Embora o feijoeiro comum responda positivamente à fertilização com fósforo (Al-Niemi et al., 1997), em regiões da América Latina e África esta prática é limitada em função da baixa renda dos agricultores (Horst et al., 2001). A elevada capacidade de fixação de fósforo em solos dessas regiões também restringe sua disponibilidade (Nielsen et al., 1998; Horst et al. 2001).

Há poucos trabalhos e pesquisas com relação à otimização do sistema radicular em resposta à disponibilidade de água e nutrientes, principalmente quando se trata da combinação de vários fatores, tais como profundidade, mobilidade de recursos como água, e superficialidade para alocar recursos imóveis como o P. 
O estudo do sistema radicular está associado a metodologias destrutivas, trabalhosas e de difícil interpretação. Para possibilitar observações não destrutivas do sistema radicular, foi incluído um estudo preliminar para a avaliação do uso de um medidor portátil de capacitância para inferir a massa do sistema radicular da cultura em questão.

A definição da melhor localização do fertilizante fosfatado adicionado ao solo, para a obtenção do máximo aproveitamento, possibilitaria a utilização de menores quantidades de fertilizante por unidade de área.

Foram realizados experimentos preliminares que tiveram os seguintes objetivos específicos: (i) estabelecer a unidade de medida de capacitância e definir a altura na planta mais adequada para o posicionamento do eletrodo do medidor de capacitância, em solução nutritiva, para obter maiores valores de correlação com valores de fitomassa total do feijoeiro comum; (ii) estabelecer unidade de medida e, posicionamento do eletrodo na haste do feijoeiro comum, para determinação de valores de capacitância, em meio sólido, provido de dois teores diferentes de fósforo, para obter maiores valores de correlação com outros atributos da planta; (iii) definir, entre diferentes genótipos do feijoeiro comum, os genótipos mais contrastantes em relação ao enraizamento adventício em diferentes níveis de fósforo no substrato. O presente estudo teve como objetivos: (i) verificar o efeito da localização do P no substrato sobre o desenvolvimento, distribuição do sistema radicular e produtividade do feijoeiro comum; (ii) estabelecer metodologia para determinar valores de capacitância que viabilizem elaborar relações funcionais, com outros atributos da planta; (iii) verificar o efeito de diferentes teores de P sobre fitomassa seca de parte aérea e diversos aspectos do sistema radicular de diferentes genótipos do feijoeiro comum. 


\section{REVISÃO DE LITERATURA}

\subsection{Fósforo no solo}

A maioria dos ambientes naturais apresenta condições subestimadas com relação aos recursos, principalmente, no que diz respeito ao fósforo (Al-Niemi et al., 1997; López-Bucio et al., 2000; Hinsinger, 2001; Fan et al., 2003). A baixa disponibilidade de fósforo é considerada a principal limitação da produção agrícola em condições úmidas tropicais e subtropicais (Nielsen et al., 1999), juntamente com a disponibilidade de água e nitrogênio e a definição do genótipo e população.

Os solos tropicais são caracterizados pelo elevado grau de intemperização e pelos baixos teores de fósforo na forma disponível às plantas, localizado, preferencialmente, nos horizontes superficiais, decrescendo conforme aumenta a profundidade do solo (Bonser et al., 1996). Nessas condições, a falta de estoque de fósforo eleva o preço dos fertilizantes; além disso, quando aplicado ao solo poder ser fixado em formas não disponíveis às plantas, como óxidos de ferro e alumínio (Nielsen et al., 1999).

Em solos tropicais, o fósforo é o nutriente limitante para a produção agrícola (Hall \& Schawartz, 1994; López-Bucio et al., 2002). Por apresentar baixa mobilidade no solo (Marschner, 1995; López-Bucio et al., 2002), o fósforo, freqüentemente, é o fator que restringe o crescimento de plantas (Hinsinger, 2001).

O movimento de fósforo no solo ocorre, principalmente, por difusão (curta distância). Ao absorver, a planta está contribuindo para a heterogeneidade espacial do fósforo (Lynch \& Brown, 2001).

O fósforo pode estar presente no solo, mas, em função da sua elevada reatividade, pode estar indisponível à planta (Holford, 1997; Shachtman et al., 1998) e, freqüentemente, em teor inferior à adequada para diversas culturas (Al-Niemi et al., 
1997; Hinsinger, 2001), dentre as quais o feijoeiro comum (Fösher, 1988; Hinsinger, 2001), especialmente quando se considera solo de regiões tropical e subtropical (Hinsinger, 2001). Essa condição é característica de muitos solos nativos (Nielsen et al., 1998) e limita o crescimento de plantas em diversos ecossistemas terrestres (Bonser et al., 1996; Nielsen et al., 2001; Fan et al., 2003; Ho et al., 2004).

Nas regiões tropicais e subtropicais, é comum a ocorrência de solos com baixa disponibilidade de fósforo (Bonser et al., 1996; Nielsen et al., 1998). Nessas regiões, em que a fertilidade do solo restringe a produção agrícola (Lynch et al., 1992; López-Bucio et al., 2002), localizam-se agrossistemas que sustentam ampla fração da humanidade (Fan et al., 2003). Estima-se que 5,7 bilhões de hectares apresentem baixa disponibilidade de fósforo para uma produção agrícola ótima (Hinsinger, 2001).

O transporte de fósforo para as plantas depende, primariamente, do coeficiente de difusão, determinado por temperatura, umidade, estrutura e poder tampão do solo. O crescimento das raízes é decisivo para o estabelecimento do contato entre solo e raiz, sendo função das propriedades físicas do solo e por fatores químicos como toxidez por alumínio e deficiência de cálcio em solos ácidos (Horst et al., 2001).

Diversos sistemas agrícolas apresentam até $80 \%$ do fósforo no solo na forma imóvel, ou seja, indisponível para ser absorvido pelas plantas por estar precipitado, adsorvido, ou convertido para a forma orgânica (Holford, 1997).

O fósforo é encontrado no solo, tanto na forma inorgânica como na orgânica. De 20 a 80\% do fósforo na forma orgânica apresenta-se como ácido fítico (inositol hexafosfato). Na fração inorgânica, o fósforo faz parte da constituição de até 170 minerais (Holford, 1997; Shachtman et al., 1998).

A concentração de fósforo inorgânico na solução do solo é dependente do $\mathrm{pH}$, e varia amplamente para cada tipo solo (Hinsinger, 2001; Shachtman et al., 1998; Zaiter \& Saade, 1993). As reações de protonação e desprotonação definem o pH e a concentração de íons na solução do solo (Hinsinger, 2001). Os íons fosfato são derivados da dissociação do ácido orto-fosfórico. Os valores pK referentes à dissociação do $\mathrm{H}_{3} \mathrm{PO}_{4}$ para $\mathrm{H}_{2} \mathrm{PO}_{4}{ }^{-}$e então para $\mathrm{HPO}_{4}{ }^{2-}$ são, respectivamente, 2,1 e 7,2. A maioria dos estudos revela que a absorção máxima de fósforo pelas plantas ocorre em $\mathrm{pH}$ entre 5,0 a 6,0, 
sugerindo que esse elemento é absorvido, preferencialmente, na forma monovalente $\left(\mathrm{H}_{2} \mathrm{PO}_{4}{ }^{-}\right)$(Shachtman et al., 1998; Salisbury \& Ross, 1992).

O íon fosfato é adsorvido em função das cargas positivas de óxidos de ferro e de alumínio, ou se combinar com diferentes metais, tais como cálcio, ferro e alumínio (Hinsinger, 2001). Em solos ácidos, o fósforo forma compostos insolúveis com ferro, alumínio e matéria orgânica. Nos solos alcalinos, liga-se a cálcio e magnésio formando compostos moderadamente solúveis (Holford, 1997; López-Bucio et al. 2002).

O fósforo se movimenta no solo através de difusão (Horst et al., 2001). Conforme ocorre a absorção, é gerado um gradiente de concentração desse elemento na rizosfera, que é a força motriz para a difusão do fósforo para as raízes (Hinsinger, 2001).

A aquisição de fósforo pelas diferentes culturas, seja esse proveniente de fertilizantes fosfatados ou não, é função das propriedades do solo e da planta. Essa é definida pela atividade biológica, pelo transporte e pelo contato do fósforo com as raízes, e pelas relações entre adsorção e dessorção, precipitação e dissolução (Horst et al., 2001). Essas relações são influenciadas por propriedades químicas do solo, como $\mathrm{pH}$, concentração de outros ânions que competem nas reações de trocas, e pela concentração de metais como cálcio, ferro e alumínio, que se precipitam com o fósforo (Hinsinger, 2001). As atividades biológicas são afetadas, diretas ou indiretamente, pela temperatura e pelo conteúdo de água do solo (Horst et al., 2001).

Em função da elevada reatividade do fósforo, podem ocorrer solos que apresentem um teor total elevado e, mesmo assim, ter o fósforo indisponível às plantas (López-Bucio et al. 2002). Geralmente, o fósforo inorgânico ocorre em baixa concentração na solução por se ligar a diferentes minerais (Hinsinger, 2001).

A distribuição de nutrientes em solos naturais é heterogênea ao longo do tempo e do espaço (Hinsinger, 2001). Na maioria dos solos a disponibilidade de fósforo é estratificada, e decresce com aumento da profundidade (Pothuluri et al., 1986; Bonser et al., 1996; Miller, 1998; Hinsinger, 2001).

Uma vez que o fósforo apresenta baixa mobilidade no solo (Marschner, 1995), o fósforo, proveniente da decomposição de folhas e resíduos de plantas, permanece nos horizontes superficiais (Hinsinger, 2001). Na superfície do solo, ocorre maior 
mobilização do fósforo em função da presença de matéria orgânica (López-Bucio et al., 2002), da atividade de microrganismos e do $\mathrm{pH}$ mais próximo da neutralidade os quais definem processos de mobilização e mineralização do fósforo (Horst et al., 2001). Em solos agrícolas, o cultivo e as fertilizações aumentam a disponibilidade de fósforo na superfície (Lynch \& Brown, 2001).

A manutenção de restos de cultura evita que o fósforo seja exportado para fora do sistema. Embora grande parte deste elemento seja translocado para os órgãos reprodutores, retirados na colheita, essa prática apresenta efeito positivo nas propriedades físicas e biológicas do solo. O uso de restos culturais e de matéria orgânica proporciona lenta liberação de fósforo através da decomposição, limitando sua fixação. A prática de rotação de culturas e de manutenção dos restos de culturas na área empregando plantas eficientes para obtenção de $\mathrm{P}$, bem como a adubação verde, facilitam a obtenção do fósforo pela cultura principal (Horst et al., 2001). Embora esses tratos culturais elevem o fósforo no sistema, não eliminam a necessidade da fertilização com fósforo mineral (Horst et al., 2001).

Se, em algumas regiões, o uso de fertilizantes fosfatados é inviável em função do elevado preço, em outras, seu uso tem sido exacerbado, o que tem despertado grande preocupação com a poluição do meio ambiente. Em ambas as situações, o melhoramento

genético constitui uma alternativa efetiva para a economia na fertilização (Aggarwal et al., 1997). A utilização de espécies e variedades cultivadas mais eficientes no uso deste elemento é essencial para um sistema agrícola sustentável (Araújo et al., 1998; Lynch, 1998). Para tal, deve ser considerada a habilidade da planta crescer e produzir em condições não ótimas de disponibilidade de fósforo (Lynch \& Beebe, 1995; Yan et al., 1995). Embora alguns mecanismos que confiram eficiência no uso do fósforo tenham sido elucidados, ainda pouco foi aplicado no sistema agrícola (Horst et al., 2001).

\subsection{Fósforo na planta}

O fósforo é considerado onipresente na planta, por estar envolvido em quase todos os processos metabólicos (Bennett, 1994). Sua mobilidade na planta (Salisbury \& Ross, 1992) possibilita que o mesmo átomo de $\mathrm{P}$ passe de um composto para outro, 
diversas vezes (Kolek \& Holobrada, 1994). Além disto, a elevada mobilidade permite o seu acúmulo em folhas novas, em flores e sementes (Salisbury \& Ross, 1992).

O elemento fósforo $(\mathrm{P})$ é essencial ao crescimento, ao desenvolvimento e à reprodução das plantas (Bennett, 1994; Holford, 1997; López-Bucio et al. 2002) com importante papel no processo de maturação e formação de sementes (Bennett, 1994).

A baixa disponibilidade de $\mathrm{P}$ é a principal limitação para a produção de plantas em ecossistema natural ou agrícola (Lynch \& Brown, 2001). O requerimento de P para ótimo crescimento está na faixa de $0,3-0,5 \%$ da fitomassa seca da planta durante o período de tempo entre a emergência e o florescimento (Shachtman et al., 1998; Marschner, 2002). Seu teor, no citoplasma, varia de 5 a $20 \mathrm{mmol}^{-\mathrm{L}^{-1}}$ e, na seiva do xilema, de 0,04 a 0,2 mmol.L ${ }^{-1}$ (Kolek \& Holobrada, 1994).

Na planta, o fosfato pode constituir moléculas simples ou complexas, com maior ou menor estabilidade (Marschner, 2002). O primeiro aceptor de P é desconhecido, embora seja evidente que sua absorção esteja relacionada com a respiração (Kolek \& Holobrada, 1994). Em contraste com $\mathrm{N}$ e S, o fósforo não é reduzido na planta; é mantido como fosfato (Salisbury \& Ross, 1992; Kolek \& Holobrada, 1994; Marschner, 2002). Em pH fisiológico, ocorre, preferencialmente, como $\mathrm{H}_{2} \mathrm{PO}_{4}{ }^{-}$, tanto na forma inorgânica, como orgânica (Marschner, 2002). O “pool” de compostos orgânicos nas plantas é dividido em quatro grupos: DNA, RNA, fosfolipídeos e éster-fosfoglicídeos (Kolek \& Holobrada, 1994).

É componente chave para moléculas como ácido fítico, coenzimas, acúcaresfosfato, nucleotídeos, ácido nucléico, fosfolipídeos e ATP (Taiz \& Zeiger, 2003). O fósforo inorgânico também está envolvido no transporte de elétrons, no controle de reações enzimáticas e na regulação de vias metabólicas (Bennett, 1994; Shachtman et al., 1998).

O fósforo inorgânico (Pi), assim que é absorvido, é convertido em poucos minutos para a forma orgânica e, em seguida, é novamente convertido para a forma inorgânica, para ser transportado no xilema (Kolek \& Holobrada, 1994; Marschner, 2002). Nos principais compostos orgânicos, o ortofosfato esterifica o grupo $\mathrm{OH}^{-}$do 
componente orgânico (sacarídeos, alcoóis), ou se liga através do pirofosfato, ou de outro grupo de fosfato (Kolek \& Holobrada, 1994).

\subsection{Funções do fósforo na planta}

\subsubsection{Função estrutural}

O P apresenta função estrutural na constituição de ácidos nucléicos (Bennett, 1994; Shachtman et al., 1998), que são unidades que formam o DNA e o RNA, responsáveis pela transferência da informação genética (Bennett, 1994). Em ambos os casos, o fosfato forma pontes com unidades de nucleotídeos, gerando macromoléculas. Nas membranas celulares, está presente em fosfolipídeos (Bennett, 1994; Shachtman et al., 1998) que conferem a estrutura às mesmas (Marschner, 2002).

\subsubsection{Transferência de energia}

Ésteres fosfato (C-P) e fosfatos ricos em energia (P-P) são fundamentais ao metabolismo das células. Existem mais de 50 tipos de ésteres formados a partir de fosfato e álcool-açúcares. A maioria dos ésteres fosfato é intermediária nas vias de biossíntese e degradação. Sua função e sua formação estão diretamente relacionadas ao metabolismo energético das células. A síntese de amido, por exemplo, utiliza a energia proveniente do ATP (adenosina trifosfato) e suas moléculas intermediárias (ADP e AMP, adenosina di e monofosfato). Outras moléculas energéticas diferem do ATP na base nitrogenada, como a uridina difosfato (UTP) e guanosina trifosfato (GTP), requeridas para as sínteses, respectivamente, de sacarose e celulose. Desfosforilação é, geralmente, uma reação hidrolítica catalizada por proteína fosfatases. Fosforilação de proteínas é considerada o fator chave na transdução de sinais como, por exemplo, em respostas mediadas por fitocromos. Um exemplo é o aumento da assimilação de nitrato nas folhas submetidas à luz. PEP carboxilase é uma das enzimas chave reguladas por fosforilação, tanto em plantas C3 como em plantas C4. Em plantas CAM e C4, a fosforilação aumenta a atividade da PEP carboxilase, ao mesmo tempo em que a enzima se torna menos sensível ao controle negativo da concentração de malato (Salisbury \& Ross, 1992; Marschner, 2002; Taiz \& Zeiger, 2003). 


\subsubsection{Compartimentalização e papel regulador do fosfato inorgânico}

O fósforo é estocado em duas formas principais, como polifosfato e como fitato. A síntese de polifosfato ocorre a partir de polímeros de $\mathrm{Pi}$, com ligações do tipo pirofosfato, tão energéticas quanto as ligações da molécula de ATP. Portanto, funcionam no armazenamento de energia, controlando o nível de Pi celular. Fitato é a forma de armazenamento de fósforo inorgânico que ocorre em sementes e grãos de pólen, raízes e tubérculos (Marschner, 2002).

Em muitas reações enzimáticas, o Pi é tanto substrato como produto (exemplo: $\mathrm{ATP} \rightarrow \mathrm{ADP}+\mathrm{Pi}$ ). Além disso, o Pi controla algumas reações enzimáticas (Bennett, 1994). A compartimentalização de Pi é essencial para a regulação de vias metabólicas no citoplasma e no cloroplasto. Na célula, ocorre preferencialmente no citoplasma e no vacúolo (Kolek \& Holobrada, 1994). O vacúolo age como reservatório de Pi (Kolek \& Holobrada, 1994; Marschner, 2002), com 85-90\% do Pi da célula (Marschner, 2002) e, geralmente, é armazenado na forma de polifosfatos (Kolek \& Holobrada, 1994). As plantas deficientes em fósforo, após a exaustão do Pi armazenado nos vacúolos, estacionam o seu crescimento (Kolek \& Holobrada, 1994), e passam a apresentar praticamente todo o Pi no citoplasma e nos cloroplastos (Kolek \& Holobrada, 1994; Marschner, 2002).

Nas folhas, variações de até $20 \%$ do teor de Pi não afetam a fotossíntese. A concentração de Pi no citoplasma é regulada, em uma faixa estreita, pela homeostase efetiva do fosfato, onde a concentração de Pi do vacúolo atua como tampão. Sob deficiência de P, a concentração citoplasmática de Pi na folha pode decrescer de valores próximos de $5 \mathrm{mM}$ para menores de 0,2 $\mathrm{mM}$. Simultaneamente, o nível de fosfato energético pode cair de 20 a 30\% do seu nível original. Aumento na respiração alternativa parece representar uma adaptação metabólica (Marschner, 2002).

\subsubsection{Função na fotossíntese}

Na redução do $\mathrm{CO}_{2}$, o fósforo participa na forma inorgânica e também como parte da composição das moléculas de NADPH, ATP, PGA, GAP e ribulose bifosfato (RuBP). A RuBP é um composto de 5 carbonos, empregado como receptor de $\mathrm{CO}_{2}$ 
(RuBP; com RuBPcarboxilase (Rubisco) $\rightarrow 2$ fosfoglicerato (PGA)). Depois da carboxilação da RuBP, são formadas duas moléculas de 3 carbonos (fosfoglicerato, PGA), por isso, plantas $C_{3}$. A enzima RuBPcarboxilase (Rubisco) viabiliza a formação da PGA, em seguida, PGA é reduzida a GAP (gliceraldeído-3-fosfato), empregando NADPH e ATP formados a partir da fotossíntese. O ciclo de Calvin, ou seja, a fixação de $\mathrm{CO}_{2}$ via $\mathrm{C}_{3}$, ocorre nos cloroplastos. As enzimas responsáveis pela fixação de $\mathrm{CO}_{2} \mathrm{e}$ síntese de carboidratos localizam-se no estroma dos cloroplastos, onde NADPH e ATP são fornecidos pelos tilacóides. A RuBP, receptora de $\mathrm{CO}_{2}$, deve ser regenerada no ciclo de Calvin-Benson. O carboidrato que restar é utilizado para a síntese de amido, ou transferido para o citoplasma como um composto de 3 carbonos para a síntese de monoe dissacarídeos. A taxa de liberação de compostos contendo 3 carbonos pelos cloroplastos é controlada pela concentração de fósforo inorgânico no citoplasma (Pollock et al., 1992; Salisbury \& Ross, 1992; Marschner, 2002; Taiz \& Zeiger, 2003).

O fósforo inorgânico, portanto, apresenta um forte efeito regulador na taxa de acúmulo de amido e na liberação de açúcares pelo cloroplasto (Pollock et al., 1992; Bennett, 1994; Marschner, 2002). Além disso, a síntese de sacarose nas folhas também é regulada pelo equilíbrio de compostos providos de P (Pollock et al., 1992). Em plantas $\mathrm{C}_{4}$, o fosfoenol piruvato (PEP) age como receptor de $\mathrm{CO}_{2}$, formando oxaloacetato, que é reduzido a malato (Salisbury \& Ross, 1992; Marschner, 2002; Taiz \& Zeiger, 2003).

\subsubsection{Fornecimento de fósforo e crescimento de plantas}

O crescimento do sistema radicular é bem menos inibido sob deficiência de $\mathrm{P}$, gerando a típica redução da relação entre parte aérea e raiz das plantas. Como regra, o decréscimo nessa relação é relacionado à elevada partição de carboidratos alocados para as raízes em plantas deficientes em fósforo, indicado pelo aumento na quantidade de sacarose nas raízes (Marschner, 2002).

Em contraste com outros nutrientes que se movem no solo através do fluxo de massa, a mobilidade do fósforo no solo é dada através de difusão, o que faz sua aquisição mais dependente da exploração temporal e espacial do solo pelo sistema radicular (Barber, 1995). O fósforo apresenta uma taxa lenta de difusão $\left(10^{-12}\right.$ a $\left.10^{-15}\right)$ 
quando comparado a outros nutrientes. Como conseqüência, é comum a exaustão deste elemento nas proximidades do sistema radicular (Schachtman et al., 1998), o que torna características como a morfologia e a geometria do sistema radicular de suma importância para a maximização da absorção desse elemento. Sistemas radiculares com elevada razão entre área superficial e volume exploraram uma maior volume de solo (Lynch, 1995; Shachtman et al., 1998).

A absorção de P pelas raízes ocorre, basicamente, através de difusão (Kolek \& Holobrada, 1994), e o fluxo de massa contribui com uma pequena fração (cerca de 5\%) do mecanismo de absorção de P pelas raízes (Hinsinger, 2001). Embora o P possa ser absorvido nas formas $\mathrm{H}_{2} \mathrm{PO}_{4}{ }^{-}$e $\mathrm{H}_{2} \mathrm{PO}_{4}{ }^{-2}$, a absorção ocorre, preferencialmente, na forma monovalente (Salisbury \& Ross, 1992; Bennett, 1994). Esse processo é determinado tanto pelo $\mathrm{pH}$ como pela disponibilidade de $\mathrm{P}$, uma vez que a velocidade de absorção diminui quando seu teor é limitado (Salisbury \& Ross, 1992). A absorção ocorre, a princípio, nas células da epiderme, embora o principal local de absorção seja o tecido cortical. Depois da saturação do apoplasto, ocorre o transporte ativo que é decorrente do gradiente eletroquímico $(\mathrm{pH})$, onde mais de um íon $\mathrm{H}^{+}$é empregado para cada ânion monovalente de P, e ocorre o antiport de $\mathrm{OH}^{-}$(Kolek \& Holobrada, 1994).

Do ponto de vista fisiológico, existem dois tipos de sistemas de absorção de P. Um, com transportadores de elevada afinidade, que ocorre quando a concentração de fósforo na solução do solo encontra-se na faixa de micromolares, e outro, com transportadores de baixa afinidade, quando a concentração ocorre na faixa de milimolares. Entretanto, em função da baixa concentração de fósforo na rizosfera, somente o sistema de alta afinidade (baixo Km, Michaelis-Menten) parece operar (Ragothama, 1999; Hinsinger, 2001).

O balanço de ânions e cátions (Horst et al., 2001), ou seja, a concentração de metais (Ca, Fe e $\mathrm{Al}$ ) e de elementos tidos como “competidores” (bicarbonato e ânions carboxílicos) afetam condições químicas (Hinsinger, 2001), capacidade de redução e atividades de raízes e de microrganismos (Horst et al., 2001). Isso altera a concentração de fósforo na solução do solo e a disponibilidade deste elemento (Hinsinger, 2001), 
viabilizando a obtenção de fósforo tanto na forma inorgânica e como orgânica (Horst et al., 2001).

As plantas apresentam vários mecanismos estratégicos de adaptação à baixa disponibilidade de fósforo; estes, geralmente, servem para aumentar a mobilidade e a absorção do P (Ragothama, 1999).

A disponibilidade do fósforo inorgânico na rizosfera é definida pela espécie, estado nutricional da planta e condições do solo (Hinsinger, 2001). As plantas desenvolveram propriedades que contribuem para o uso mais eficiente de fósforo e para a mobilização deste a partir de frações menos disponíveis (Horst et al., 2001).

A modificação de fatores relacionados à disponibilidade de $\mathrm{P}$, tais como alteração do pH da rizosfera, através de processos como trocas gasosas e exsudação de compostos como $\mathrm{OH}^{-}$(Horst et al., 2001), prótons, ácidos orgânicos (López-Bucio et al., 2002; Schachtman et al., 1998) e fosfatases (Lynch \& Rodriguez, 1994; Lynch \& Beebe, 1995; Lynch \& Brown, 2001; Fan et al., 2003) influenciam na eficiência de absorção de fósforo pela planta. Ácidos orgânicos, liberados pela raiz, podem favorecer o aumento da solubilidade de compostos contendo fósforo (Schachtman et al., 1998; López-Bucio et al., 2000; Hinsinger, 2001; Horst et al., 2001).

Mecanismos sugeridos para aumentar a eficiência de fósforo nas plantas incluem menor requerimento de fósforo nos tecidos, aumento na reserva de fósforo das sementes e mudanças no desenvolvimento fenológico (Lynch \& Beebe, 1995). O fósforo pode alterar o desenvolvimento da planta de duas maneiras, atuando como nutriente que estimula a produção de fitomassa, ou funcionando como sinal que regula mudanças na arquitetura radicular (Figura 1) (López-Bucio et al., 2002). 


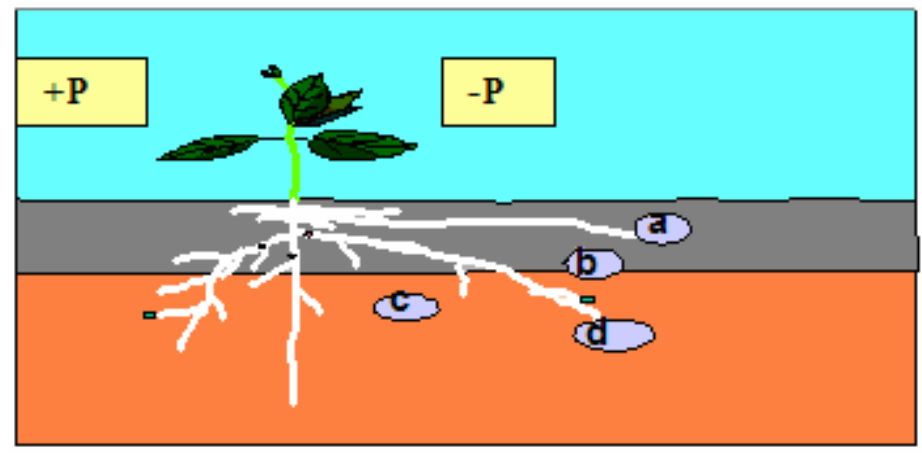

Figura 1 - Regulação da arquitetura do sistema radicular em função do teor de fósforo no solo. Baixo teor de fósforo (a) estimula a produção de raiz adventícia, (b) aumenta raízes basais na superfície, (c) aumenta a dispersão das raízes laterais e (d) aumenta a densidade e elongação dos pêlos radiculares, que favorece absorção de fósforo (Adaptado de Lynch \& Brown, 2001)

A capacidade da planta em adquirir fósforo, em condições adversas, depende de características adaptativas, que incluem mecanismos que elevam a exploração do solo (Schachtman et al., 1998; López-Bucio et al., 2002). Esses mecanismos envolvem plasticidade radicular, taxa de alongamento das células radiculares e de raízes (Marschner, 2002), arquitetura radicular, proliferação de pêlos radiculares (Bates \& Lynch, 1996) e a simbiose com micorrizas e algumas bactérias (Lynch \& Beebe, 1995).

Plantas adaptadas a ambientes inférteis alocam grande proporção de carboidrato para o aumento da fitomassa seca da raiz (Larigaurderie \& Richards, 1994). A disponibilidade de fósforo regula vários processos, como o padrão de distribuição de fitomassa (Nielsen et al., 2001).

Plantas deficientes em fósforo exibem maior alocação de carboidratos para 0 sistema radicular, tanto em função de relações alométricas (Nielsen et al., 2001) como em função de aumento na alocação de fitomassa para o sistema radicular (Cakmak et al., 1994; Nielsen et al., 2001), influenciando a aquisição de carbono e de outros recursos. Bonser et al. (1996) não verificaram redução na concentração de fósforo no sistema radicular, o que indica que a alocação deste elemento viabiliza o crescimento radicular e, conseqüentemente, a aquisição de P pelo aumento da exploração do solo. 
Vários estudos relacionam o efeito da disponibilidade de fósforo com o comprimento e a densidade de pêlos radiculares (Bates \& Lynch, 1996; Ma et al., 2001; López-Bucio et al., 2002; Fan et al. 2003). O aumento da densidade de pêlos é, parcialmente, função de mudanças anatômicas, que geram o aumento de tricrobastos (Ma et al., 2001). Assim como os pêlos radiculares, a simbiose com micorrizas (Lynch \& Beebe, 1995; Bates \& Lynch, 1996; Ma et al., 2001) e a redução do diâmetro radicular (Nielsen et al., 1998; Horst et al., 2001) elevam o contato entre a raiz e o solo.

Em função da baixa mobilidade deste elemento no solo, as adaptações à baixa disponibilidade de fósforo incluem a obtenção de fósforo com custo mínimo de carbono, através de mudanças que incluem modificações na arquitetura radicular (Nielsen et al., 1999; Lynch \& Brown, 2001; Hinsinger, 2001; Fan et al., 2003), no padrão de ramificação (Bates \& Lynch, 1996; Borch et al., 1999; López-Bucio et al., 2002), no aumento do crescimento radicular (Nielsen et al. 1999; Hinsinger, 2001), no comprimento total das raízes, no alongamento de pêlos radiculares e na formação de raízes laterais (Lynch, 1995; Lynch, 1998; Bates \& Lynch, 1996; López-Bucio et al., 2002).

Em resposta à deficiência nutricional, ocorre a canalização de carbono e energia para a formação de um sistema radicular capaz de explorar os diferentes horizontes do solo (Nielsen et al., 1998; Schachtman et al., 1998; López-Bucio et al., 2000), bem como maior área da superfície do solo, onde, normalmente, ocorre maior disponibilidade de nutrientes (López-Bucio et al., 2002).

A síntese de amido e o transporte de carboidratos são fortemente influenciados pelo fósforo inorgânico (Fredeen et al.,1989; Marschner, 2002). Maiores taxas de triose$\mathrm{P}$ ou triose-P/P inorgânico nos cloroplastos favorecem a formação de amido, em detrimento da síntese de sacarose através da ativação da pirofosfatase ADP-glicose, enzima chave para síntese de amido (Cakmak et al., 1994).

Plantas com adequado suprimento de fósforo apresentaram mais carbono assimilado ao longo do tempo (Nielsen et al., 1998). A deficiência de P provoca aumento na atividade de enzimas envolvidas com a síntese de sacarose em folhas e raízes (Marschner, 2002). O acúmulo de amido, nos tecidos de plantas deficientes em 
fósforo é o reflexo da limitação de fósforo nos tecidos com alta atividade na parte aérea como, por exemplo, a expansão foliar (Fredeen et al., 1989; Cakmak et al., 1994). Ciereszko \& Barbachowska (2000) sugerem que o aumento de sacarose nas raízes também tenha efeito osmoregulador e, portanto, eleve a capacidade de absorção das raízes.

O aumento na alocação de carbono para o sistema subterrâneo é a primeira conseqüência do estresse causado pela baixa disponibilidade de P (Nielsen et al., 1998). Plantas deficientes em fósforo apresentam crescimento mais lento e aumento da relação entre raiz e parte aérea (Lynch et al., 1992; Cakmak et al., 1994; Halsted \& Lynch, 1996; Nielsen et al., 1998; López-Bucio et al., 2002). Além disso, a limitação de fósforo retarda a formação de órgãos reprodutivos. A iniciação de flores é retardada, o número flores reduzido, e a formação de sementes restringida (Marschner, 2002).

A taxa de crescimento da parte aérea e o alongamento primário da raiz são determinados pela concentração interna de fósforo. O efeito do fósforo sobre a formação de raízes (Fredeen et al., 1989) laterais e pêlos radiculares está relacionado à disponibilidade externa de fósforo que à concentração interna desse elemento (LópezBucio et al., 2002). O custo do fósforo empregado para o desenvolvimento radicular é maior do que o fósforo utilizado no desenvolvimento de folhas, uma vez que nas raízes parece não ocorrer remobilização de fósforo, como no restante da planta durante a senescência (Snaap \& Lynch, 1996). A deficiência de fósforo proporciona redução na parte aérea foliar através da limitação do número e da expansão de folhas (Lynch et al., 1992, Marschner, 2002), da ramificação da parte aérea, da redução na taxa de assimilação de carbono, além de promoverem senescência prematura de folhas, que limita a produção de sementes em plantas deficientes em fósforo (Marschner, 2002).

A expansão foliar é estreitamente relacionada à expansão das células epidérmicas (Marschner, 2002) e à concentração interna de fósforo no tecido (Cakmak et al., 1994; López-Bucio et al., 2002). Em dicotiledôneas, a expansão foliar é reduzida pela deficiência hídrica e pela deficiência de fósforo associada à redução da condutividade hidráulica do sistema radicular (Halsted \& Lynch, 1996; Marschner, 2002). A deficiência de $\mathrm{P}$ inibe severamente a taxa de crescimento foliar somente durante o dia, 
tendo pouco efeito durante a noite. Essa diferença entre dia e noite é uma resposta primária da disponibilidade de água para a expansão foliar durante o dia, causada pela baixa condutividade hidráulica do sistema radicular em função da deficiência de P (Marschner, 2002).

A restrição da expansão foliar favorece maior exportação de carboidrato para o sistema subterrâneo (Cakmak et al., 1994; López-Bucio et al., 2002). Em condições de baixa disponibilidade de $\mathrm{P}$, a maior parte do fósforo absorvido pelas raízes é retida no sistema radicular, ou seja, é utilizado para suprir a demanda local deste elemento (Snapp \& Lynch, 1996).

Em contraste com a redução na expansão foliar, a quantidade de proteína e clorofila, por unidade de área foliar, é pouco afetada. Freqüentemente, o teor de clorofila é elevado sob condições de deficiência de fósforo. Portanto, o tamanho pequeno e a cor verde escura das lâminas foliares, em plantas deficientes de P, é resultado da expansão foliar ineficiente, que conduz a um elevado número de células por unidade de área foliar (Marschner, 2002). Além disso, a limitação de fósforo provoca, principalmente em dicotiledôneas, a redução do número de nós que ramificam (Lynch et al., 1992).

O envolvimento de hormônios possui significado lógico na tradução de sinais ambientais em mudanças no hábito de crescimento e no metabolismo, visando a adaptação (Lynch, 1995). O estresse decorrente da deficiência de nutrientes afeta a síntese, o transporte, ou a sensibilidade de fitohormônios, de forma que a arquitetura radicular seja alterada (López-Bucio et al., 2002). Supõe-se que a baixa disponibilidade de fósforo aumenta a produção de etileno e/ou a sensibilidade nas raízes, o que resulta em mudança na arquitetura do sistema radicular, visando aumento na habilidade de aquisição de fósforo (Lynch \& Brown, 1997). De fato, López-Bucio et al. (2002) observaram estreita relação entre alteração do crescimento radicular e a deficiência de fósforo, e sugeriram que fitohormônios devam estar envolvidos no efeito da baixa disponibilidade de fósforo o solo sobre o ângulo de crescimento das raízes. O efeito da disponibilidade de fósforo na formação de raízes laterais ocorre sinergeticamente à mudança do ângulo de crescimento das raízes basais (Figura 2) e ao enraizamento adventício, sugerindo uma coordenação destes processos pelo mesmo mecanismo. 


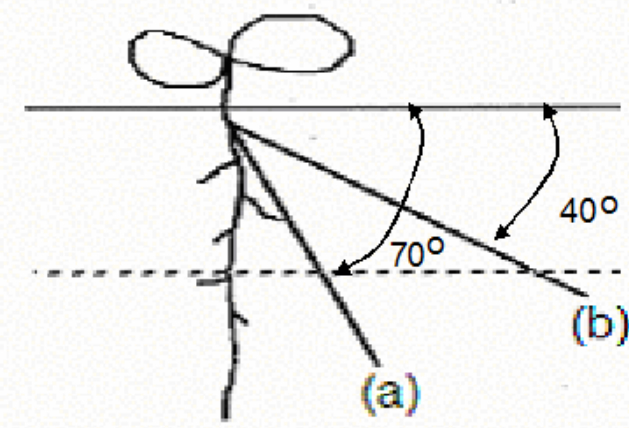

Figura 2 - Ângulo de crescimento da raiz basal dos genótipos (a) G2333 (ângulo de 70º) e (b) G19839 (ângulo de $40^{\circ}$ ) em resposta à baixa disponibilidade de fósforo no solo $\left(\right.$ Lynch $\left.^{1}\right)$

Lynch \& Brown (1997) sugerem que os mecanismos de respostas adaptativas à deficiência de P envolva o etileno, uma vez que conhecido o efeito desse hormônio na formação de raízes adventícias, na formação de raízes laterais e no gravitropismo radicular, na senescência e a abscisão de partes que a planta não pode manter. Para Jesko (1994), no entanto, as raízes adventícias e laterais bem como a formação e crescimento de pêlos radiculares são estimulados por auxina e que a interação entre os fitohormônios da parte aérea e radicular é responsável pela formação de órgãos laterais e geotropismo radicular.

O teor de fósforo já havia sido associado com a síntese de etileno em 1981, quando foi verificado que elevados teores de fosfato no meio induziram a inibição do etileno em fatias de frutas, apresentando efeito pronunciado no amadurecimento, quando a produção deste fitohormônio é maior (Fuchs et al., 1981). Bonser et al. (1996) verificam que a disponibilidade de fósforo no substrato proporciona elevação na produção de etileno e relacionaram esse fitohormônio com respostas específicas como formação de aerênquima (He et al., 1992) da arquitetura radicular, como gravitropismo e redução no ângulo de crescimento. Os mesmos autores sugerem que a auxina exerça

\footnotetext{
${ }^{1}$ LYNCH, J. Comunicação pessoal, 2003.
} 
efeito, tanto no ângulo de crescimento das raízes como no aumento do tamanho de pêlos radiculares, sob condições de baixa disponibilidade de fósforo.

López-Bucio et al. (2002) afirmam que a auxina e o etileno estão envolvidos na alteração primária do crescimento do sistema radicular e na promoção de raízes laterais e pêlos radiculares. Para Miller (1998), a facilitação da movimentação do etileno no tecido aerenquimático pode ter conseqüências para outros tipos de resposta às condições de estresse, como, por exemplo, a formação de raízes adventícias.

O aumento da fitomassa em raízes (Nielsen et al., 2001) é benéfico para a aquisição de fósforo, uma vez que esse é relativamente imóvel no solo. Entretanto, pode reduzir a taxa de crescimento da planta toda, por resultar no aumento da taxa respiratória do sistema radicular (Nielsen et al., 1998; Nielsen et al., 2001). A taxa de respiração é regulada por fatores ambientais, tal como temperatura, e pelo requerimento de energia (por exemplo, ATP para absorção de íons pela raiz), mas também pela demanda de agentes redutores e intermediários (Marschner, 2002).

A manutenção da respiração dos tecidos radiculares limita a economia de carbono em plantas deficientes de fósforo, pois estas plantas apresentam maior relação entre raiz e parte aérea (Marschner, 2002). Características anatômicas, como formação de aerênquima cortical, afetam o custo de construção e manutenção das raízes (Fan et al., 2003). A formação de aerênquima deve ter um valor adaptativo à deficiência de fósforo (He et al., 1992) por reduzir a manutenção das raízes, ou seja, o custo metabólico da exploração do solo no que diz respeito à respiração (Nielsen et al., 2001; Lynch \& Brown, 1997; Fan et al., 2003).

O termo geral usado para tecidos com amplos espaços intercelulares é denominado aerênquima e que confere aumento da eficiência metabólica (Snapp et al., 1995; Fan et al., 2003). Pode ser originado a partir da morte de células corticais e, durante este processo, ocorre remobilização de fósforo e carbono para células em alongamento e ápices em crescimento, que contribuem para o crescimento de plantas sob limitação de recursos (Nielsen et al., 2001; Fan et al. 2003). Além disso, a presença de aerênquima pode representar redução na respiração de manutenção (Fan et al., 2003; Snapp et al., 1995). 
Fan et al. (2003) elaboraram a hipótese de que a formação de aerênquima proporciona menor requerimento de fósforo pela planta, o que teria, como conseqüência, um aumento na eficiência metabólica na exploração do solo. Esses autores verificaram que a taxa respiratória não se reduz proporcionalmente com a porcentagem de aerênquima formado. Raízes que apresentam 30\% de aerênquima na área seccional apresentaram redução de $70 \%$ na taxa respiratória, quando comparado com raízes sem aerênquima.

\subsubsection{Fotossíntese e deficiência de fósforo}

Nas folhas, a fotossíntese e a partição de carbono, ao longo do dia, é fortemente afetada pela concentração de fósforo inorgânico (Fredeen et al, 1989) no estroma dos cloroplastos e pela relação entre compartimentalização do P inorgânico entre cloroplasto e citossol. A taxa fotossintética é mais afetada em plantas com baixa disponibilidade de P, sob condições de alta densidade de fluxo de fótons (Terry \& Rao, 1991). Durante o dia, a concentração de 2,0 a 2,5 mM de P inorgânico é considerada ótima para a fotossíntese. Esse processo, no entanto, é inibido quando essa concentração é inferior a 1,4 mM. Em função do grande requerimento de $\mathrm{P}$ inorgânico e de compostos intermediários (providos de fósforo em sua composição) para a fotossíntese, folhas de plantas deficientes desse elemento apresentam queda nas concentrações de P inorgânico em até 50\%, depois da transição de escuro para claro (Marschner, 2002). O efeito da disponibilidade de P na fotossíntese é centralizado na assimilação, partição e transporte de carbono (Fageria et al., 1991).

Aumento na concentração externa de fósforo inorgânico, na ordem de $1 \mathrm{mM}$, estimula a taxa fotossintética (fixação total de carbono), mas decresce a incorporação na forma de amido. A concentração de $\mathrm{P}$ inorgânico no estroma, necessária para tal inibição, é de 5 mM (Marschner, 2002). A inibição da síntese de amido, pela elevada concentração de P inorgânico, é regulada por dois processos no cloroplasto. A enzima chave para a síntese de amido, ADP-glucose pirofosfatase, é alostericamente inibida por P inorgânico e inibida por triosefosfatases. Outro mecanismo regulado pelo P inorgânico é a liberação de triosefosfatos (gliceraldeído-3-fosfato e deidroxiacetona fosfato), 
principais produtos da fixação de $\mathrm{CO}_{2}$ que deixam os cloroplastos. A liberação é controlada por um translocador fosfato em plantas $\mathrm{C}_{4}$ e CAM, é denominado fosfoenolpiruvato (PEP). Através do translocador de fosfato, a taxa de absorção de $\mathrm{P}$ inorgânico nos cloroplastos regula a liberação de fotoassimilados pelos cloroplastos (Fredeen et al., 1989; Marschner, 2002).

A fixação de $\mathrm{CO}_{2}$ no ciclo de Calvin é um processo em que 5 a 6 produtos da carboxilação são requeridos no estroma para regenerar o receptor de $\mathrm{CO}_{2}(\mathrm{RuBP})$. Baixa concentração de P inorgânico no citossol e nos cloroplastos de plantas deficientes em fósforo proporcionam aumento no acúmulo de amido (Fredeen et al., 1989) no cloroplasto e insuficiente remobilização desse durante a noite, ou crescimento reprodutivo (Marschner, 2002).

O acúmulo de amido em folhas de plantas deficientes em fósforo (Halsted \& Lynch, 1996; Fredeen et al., 1989) ocorre por duas razões: (i) baixa concentração de P inorgânico no citossol e, conseqüente baixa liberação de trioses a partir dos cloroplastos; e (ii) aumento na atividade da ADPG-pirofosfatase, devido à baixa concentração de $\mathrm{P}$ inorgânico no estroma. A utilização de trioses para a síntese de amido reduz a atividade do ciclo de Calvim e a fixação de $\mathrm{CO}_{2}$ por limitação na regeneração de RuPB. Acúmulo de amido (Fredeen et al., 1989; Halsted \& Lynch, 1996) e açúcares, em folhas de plantas deficientes de fósforo, pode, também, ser o resultado indireto de sua baixa liberação, por limitação de ATP para o carregamento do floema e baixa demanda dos órgãos-dreno (Marschner, 2002).

O envolvimento e o papel regulador do fosfato na síntese de amido e no transporte de carboidratos em células foliares ocorre da seguinte maneira: (1) ADPglucose pirofosfatase, que regula a taxa de síntese de amido, inibida por P inorgânico e estimulada por PGA; e (2) translocador fosfato que regula a liberação de fotoassimilados dos cloroplastos, que é elevado por P inorgânico, TP- triosefosfato (gliceraldeído-3fosfato, GAP; diidroxiacetona fosfato, DHAP), $\mathrm{F}_{6} \mathrm{P}$ (frutose 6-fosfato) e $\mathrm{G}_{6} \mathrm{P}$ (glucose 6fosfato) (Fredeen et al., 1989; Marschner, 2002).

Segundo González et al. (1995), existe variação nas características relacionadas à fotossíntese nas diferentes populações do feijoeiro comum. Para esses autores, a 
fotossíntese e a produtividade não estão necessariamente relacionadas, embora existam exemplos onde a maior capacidade fotossintética está relacionada com maior produtividade.

O feijoeiro comum é uma planta C3; sua fotossíntese fornece de 90 a 95\% da fitomassa seca. A fotossíntese, integrada ao longo do ciclo, deve determinar a fitomassa seca total e, portanto, a produção. Os valores de taxa de fotossíntese, ao longo da ontogênese de uma folha do feijoeiro, variam de 25 a $40 \mathrm{mg} \mathrm{CO}_{2} \mathrm{dm}^{-2} \cdot \mathrm{h}^{-1}$, quando a irradiância é de 600 a 650 W.m-2 e, o valor de IAF ao redor de 4,5 (Fageria et al., 1991).

Lynch et al. (1992) propuseram que a influência do tamanho das células paliçádicas, envolvidas na fotossíntese, afeta o peso específico da folha e, conseqüentemente, a quantidade de nitrogênio por unidade de área foliar. No mesmo trabalho verificaram variação genética no germoplama do feijoeiro comum relacionada a fatores que influenciam a taxa fotossintética, tais como, densidade de estômatos na face adaxial da folha e volume de células do parênquima paliçádico.

A taxa de assimilação de carbono não é alterada na mesma proporção que o crescimento da planta (Fredeen et al., 1989), embora o estresse decorrente da deficiência de fósforo provoque redução na fixação e na assimilação de $\mathrm{CO}_{2}$ e no teor de fósforo foliar (Lynch et al., 1992; Halsted \& Lynch, 1996; Nielsen et al., 1998). Por outro lado, a eficiência fotossintética por unidade de clorofila é bem menor em plantas deficientes em fósforo e, se a deficiência de fósforo for severo, vários parâmetros da fotossíntese, como a eficiência de carboxilação, são afetados (Marschner, 2002).

A pequena relação entre a eficiência no uso fotossintético do fósforo e o crescimento sob estresse de fósforo suporta a hipótese de que a alocação, bem como a utilização de carbono, são mais importantes que a assimilação instantânea de carbono no crescimento de plantas sob deficiência de fósforo (Lynch \& Beebe, 1995; Halsted \& Lynch, 1996).

$\mathrm{O}$ crescimento de espécies $\mathrm{C}_{3}$ é mais sensível ao suprimento de fósforo que plantas $\mathrm{C}_{4}$, embora ambos os grupos de espécies apresentem uso fotossintético de fósforo similar. A taxa de fotossíntese foliar não se mostra relacionada às respostas de crescimento. O efeito da deficiência de fósforo na atividade da Rubisco, na relação entre 
3-fosfoglicerato e RuBP, e na relação entre a concentração de RuBP no estroma e no sítio de ligação da RuBP foram diferentes em girassol $\left(\mathrm{C}_{3}\right)$ e milho $\left(\mathrm{C}_{4}\right)$. Além disto, a deficiência de fósforo provoca redução in vivo no fator especificidade de $\mathrm{CO}_{2} / \mathrm{O}_{2}$ da Rubisco, em folhas de girassol, resultando em fotorespiração mais elevada (Halsted \& Lynch, 1996).

Os sintomas visuais de deficiência de P são observados, principalmente, pela formação de plantas pequenas, com folhas pequenas de coloração verde mais escura (Salisbury \& Ross, 1992; Hall \& Schawartz, 1994), hastes mais finas e entrenós mais curtos. As folhas podem ser mal formadas, apresentando manchas necróticas e/ou acúmulo de antocianina (Taiz \& Zeiger, 2003). As folhas mais velhas apresentam, a princípio, coloração marrom e, em seguida, senescem prematuramente (Hall \& Schawartz, 1994). Em muitas espécies, o fósforo interfere no desenvolvimento fenológico (Salisbury \& Ross, 1992; Taiz \& Zeiger, 2003). A fase vegetativa fica mais prolongada, enquanto a reprodutiva é atrasada e mais curta (Hall \& Schawartz, 1994). Também é freqüentemente observado aborto de flores, formação de poucas vagens e redução no número de sementes por vagem (Hall \& Schawartz, 1994).

\subsubsection{Deficiência de fósforo em feijoeiro comum}

A produção de legumes é de suma importância nos sistemas agrícolas em todo o globo terrestre (Nielsen et al., 1999). O feijoeiro comum pertence à Família Fabácea. É o mais cultivado dentre as quatro espécies do gênero (Fageria et al., 1991). Em regiões tropicais e subtropicais, o feijoeiro comum se destaca como um importante legume (Bonser et al., 1996), que constitui uma importante fonte de proteína para mais de 500

milhões de pessoas na América Latina e África (Nielsen et al., 1999). Estima-se que mais de 50\% do feijoeiro comum desenvolvido na América Latina ocorra em solos deficientes em fósforo (Fageria et al., 1991; Nielsen et al., 1998). Países em desenvolvimento apresentam valores médios de produtividade do feijoeiro comum cerca de $10 \%$ abaixo do potencial de produtividade, principalmente em decorrência da baixa disponibilidade de fósforo (Lynch \& Beebe, 1995). 
O feijoeiro comum pode ser cultivado na maioria dos solos, de arenosos a argilosos, desde que a disponibilidade e a drenagem de água sejam adequadas (Fageria et al., 1991). Seu desenvolvimento compreende duas grandes fases, denominadas de fase vegetativa e fase reprodutiva, diferenciada entre si pela manifestação de diferentes eventos. A duração das etapas de desenvolvimento do feijoeiro pode ser afetada por alguns fatores, entre os quais, merece especial destaque o genótipo, que determina o hábito de crescimento e a precocidade das plantas, o clima e as condições de fertilidade do solo (Dourado Neto \& Fancelli, 2000). Em condições normais, o ciclo fenológico do feijoeiro comum varia de 70 a 85 dias (Fageria et al., 1991). Uma planta de feijão leva cerca de 28 a 42 dias para atingir o florescimento e 60 a 150 dias para a maturidade fisiológica (Hall \& Schawartz, 1994). A descrição e a caracterização dos estádios fenológicos podem ser evidenciadas na Tabela 1 (Dourado Neto \& Fancelli, 2000). O conhecimento e a facilidade na identificação dos estádios fenológicos do feijoeiro comum favorecem o estabelecimento de estratégias efetivas de manejo, visando a obtenção de rendimentos satisfatórios e lucrativos (Dourado Neto \& Fancelli, 2000). Sua produção é determinada tanto por características fisiológicas, como morfológicas. Geralmente, a produção é expressa através de três componentes: número de vagens por planta, número de sementes por vagem e massa das sementes (Fageria et al., 1991).

O sistema radicular do feijoeiro comum é semelhante ao de outros legumes (Fageria et al., 1991), e é típico de dicotiledôneas anuais. Como outras herbáceas, apresenta um sistema radicular principal e uma coroa de raízes basais, de onde emergem as raízes laterais (Lynch, 1995). As raízes adventícias são formadas a partir do hipocótilo (Miller, 1998), portanto, possuem origem caulinar (Lynch, 1995). Em todas as classes de raízes pode ocorrer a formação de raízes laterais (Lynch \& Brown, 2001). O sistema radicular do feijoeiro comum, sob estresse de deficiência de fósforo, apresenta redução na freqüência de ramificação lateral, simultaneamente ao aumento no comprimento dos eixos radiculares principais (Bonser et al., 1996). Raízes adventícias, em geral, apresentam menor ramificação em sistemas radiculares desenvolvidos com alta disponibilidade de fósforo, quando ocorre maior ramificação das raízes basais 
(Lynch \& Brown, 2001). As raízes podem atingir 1m de profundidade, embora as laterais, normalmente, se restrinjam aos 0,25 m de profundidade (Fageria et al., 1991).

Tabela 1. Escala fenológica referente ao feijoeiro comum (Gepts \& Fernández, 1982; Dourado Neto \& Fancelli, 2000)

\begin{tabular}{ll}
\hline Momento & \multicolumn{1}{c}{ Descrição } \\
\hline $\mathrm{V}_{0}$ & Emergência \\
$\mathrm{V}_{1}$ & Cotilédones ao nível do solo \\
$\mathrm{V}_{2}$ & Folhas primárias completamente expandidas \\
$\mathrm{V}_{3}$ & Primeira folha trifoliolada completamente expandidas \\
$\mathrm{V}_{4}$ & Terceira folha trifoliolada completamente expandidas \\
$\mathrm{R}_{5}$ & Aparecimento dos primeiros botões florais \\
$\mathrm{R}_{6}$ & Aparecimento da primeira flor aberta \\
$\mathrm{R}_{7}$ & Aparecimento da primeira vagem \\
$\mathrm{R}_{8}$ & Primeiras vagens cheias \\
$\mathrm{R}_{9}$ & Modificação da cor das vagens (ponto de maturidade fisiológica) \\
\hline
\end{tabular}

O crescimento radicular é influenciado por condições ambientais (Fageria et al., 1991). Lynch \& Brown (2001) associaram a forma do sistema radicular de uma plântula de feijoeiro com o formato de um guarda-chuva. Nesta analogia, as raízes basais seriam a "cobertura”, e a principal, o “cabo” do guarda-chuva. Ge et al. (2000) apresentaram a simulação do sistema radicular do feijoeiro comum com diferente ângulo de crescimento, mostrando que exploram diferentes regiões do solo. A resposta das raízes basais à gravidade determina a profundidade do sistema radicular. Usando a analogia feita por Lynch \& Brown (2001), o sistema radicular mais superficial é semelhante a um guarda-chuva aberto.

A deficiência em fósforo é considerada a limitação primária para a produtividade do feijoeiro comum em regiões tropicais (Yan et al., 1995). No solo, o teor de fósforo 
considerado crítico para o feijoeiro comum é de 15 mg. $\mathrm{kg}^{-1}$ (Bray II - Yan et al., 1995). A deficiência de macronutrientes restringe o crescimento das plantas e pode conduzir à necrose de tecidos. $\mathrm{O}$ sintoma mais comum observado em feijoeiro, quando submetido à deficiência de fósforo, é a coloração verde mais escura nas folhas (Halsted \& Lynch 1996; Marschner, 2002). O aumento na disponibilidade de fósforo no substrato, no entanto, aumenta a tolerância de plantas de feijoeiro comum ao $\mathrm{NaCl}$ e às injúrias foliares (Zaiter \& Saade, 1993).

Fan et al. (2003) verificaram que o feijoeiro comum, em condições de deficiência de fósforo, apresenta redução do crescimento secundário e atraso no desenvolvimento radicular. Segundo esses autores, o atraso no desenvolvimento secundário em reposta a limitação da disponibilidade de P, provavelmente, consiste em uma estratégia adaptativa que visa, através do crescimento primário, a concentração dos recursos na exploração do solo (Fan et al., 2003).

Diversos autores observaram uma ampla variação genética no germoplasma do feijoeiro comum em características associadas à capacidade de adaptação a condições de baixa disponibilidade de fósforo (Yan et al., 1995; Miller, 1998; López-Bucio et al., 2002) e água (Bonser et al., 1996; López-Bucio et al., 2002). Muitos componentes da arquitetura radicular respondem com plasticidade às condições do meio-ambiente, especialmente com relação à disponibilidade de fósforo (Ge et al., 2000; Lynch \& Brown, 2001; Rubio et al., 2003).

A variabilidade com relação à eficiência no uso do fósforo (capacidade de crescer e produzir) no banco de germoplasma do feijoeiro comum (Bonser et al., 1996; Lynch \& Beebe, 1995), parece estar mais relacionada à mudança na arquitetura do sistema radicular (Lynch \& van Beem, 1993) que em modificações na rizosfera ou simbioses (Yan et al., 1995; Bonser et al., 1996).

Raízes do feijoeiro comum, consideradas eficientes (Figura 3) em condições de baixa disponibilidade de fósforo, geralmente apresentam grande plasticidade (Lynch, 1995; Bonser et al., 1996), ramificações das raízes basais superficiais (Still \& Scheible, 1998; Ge et al., 2000; Rubio et al., 2003), maior alocação de carbono para raízes adventícias (Figura 4) (Miller, 1998), aumento da dispersão de raízes laterais (Lynch, 
1995; Bates \& Lynch, 1996; Lynch, 1998) e aumento no comprimento e na densidade de pêlos radiculares (Borch et al., 1999; Hinsinger, 2001).

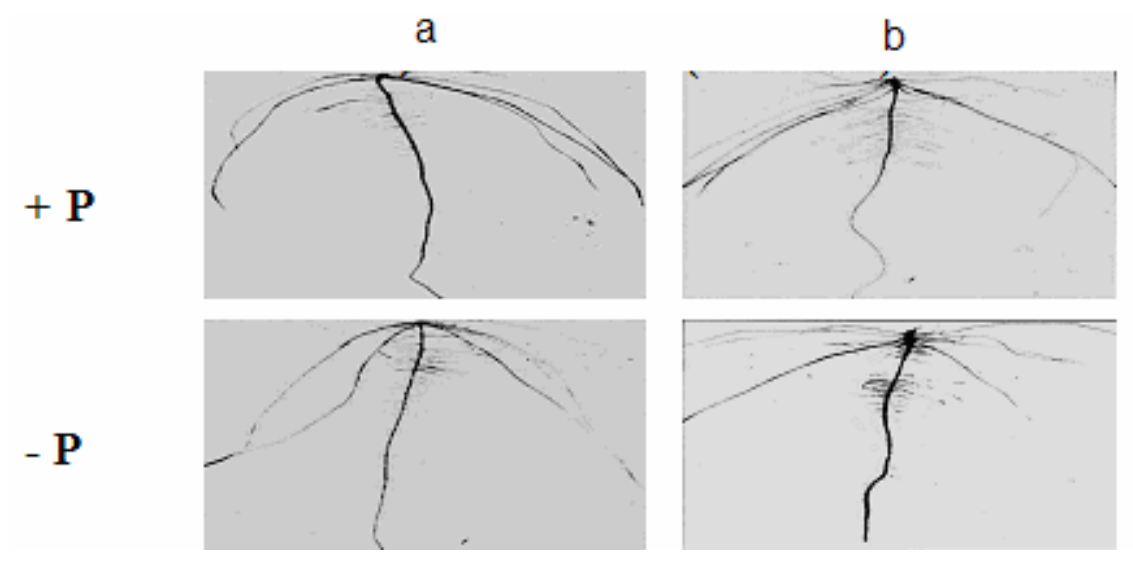

Figura 3 - Arquitetura radicular de dois genótipos de feijoeiro comum (a) DOR364 ineficiente na absorção de f'ósforo (raízes basais profundas em baixo teor de P no solo) e (b) G19833 - eficiente na absorção de f'ósforo (raízes basais superficiais em baixo teor de P no solo). Plântulas aos cinco dias em papel de germinação com alto (+P) e baixo (-P) teor de fósforo no solo (Adaptado de Liao et al., 2000)

A plasticidade de resposta do sistema radicular, com relação à disponibilidade de fósforo, é mediada pelos hormônios etileno (Bonser et al., 1996; Lynch \& Brown, 1997) e auxina (Bonser et al., 1996; López-Bucio et al., 2002). De fato, a produção de etileno por raízes do feijoeiro sob deficiência de fósforo é maior que numa condição de alto teor de fósforo (Lynch \& Brown, 1997).

Em condições de deficiência de fósforo a campo, confirmam o efeito da plasticidade na orientação das raízes em relação à gravidade, em solos com baixo teor de P (Bonser et al., 1996; Liao et al., 2001). Em estudos que consideram a variabilidade genética do feijoeiro comum e a adaptação à baixa disponibilidade de fósforo, utilizamse linhas de híbridos recombinantes, que são famílias de progênies que segregam para várias características, mas dividem a origem genética. O uso de linhas de híbridos recombinantes é vantajoso para comparar características controladas por um número 
desconhecido de genes, uma vez que estes apresentam os mesmos progenitores (Rubio et al., 2003).

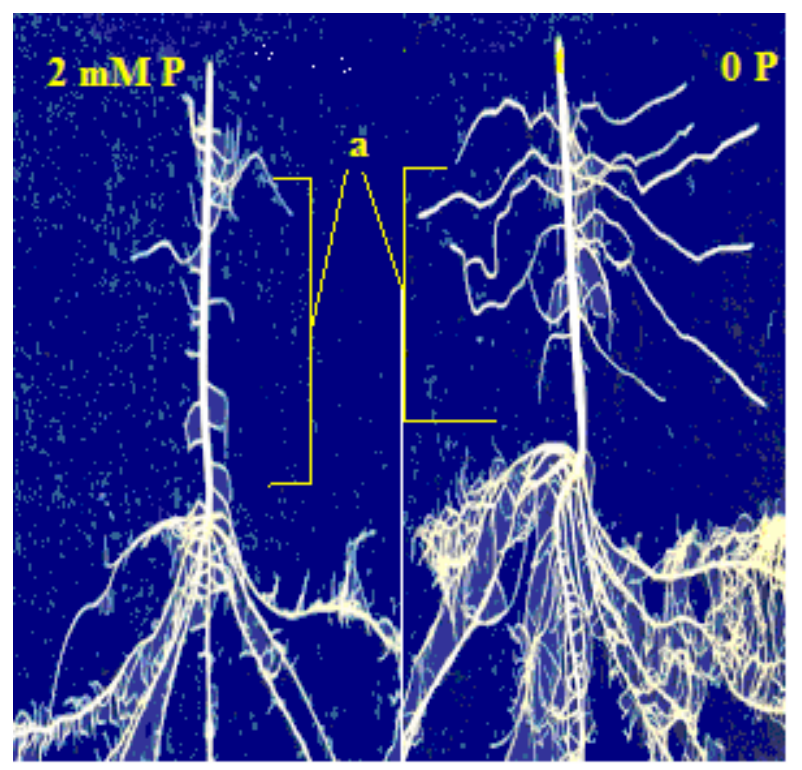

Figura 4 - Baixa disponibilidade de P aumenta substancialmente a formação de raízes adventícias (a) no feijoeiro comum. Plântulas crescendo em papel de germinação contendo solução nutritiva aos 14 dias de idade (Adaptado de Miller, 1998)

A ocorrência de aerênquima, em raízes de feijoeiro sob baixa disponibilidade de P se dá, principalmente, nas porções basais (Fan et al., 2003) e, em especial, em genótipos considerados eficientes no uso de fósforo (Nielsen et al., 2001).

Outros minerais influenciam a resposta dada pela planta à disponibilidade de fósforo e vice-versa (Marschner, 2002; Rubio et al., 2003). Um exemplo é o envolvimento do P na fixação simbiótica de N (Bennett, 1994). O crescimento e os parâmetros relacionados à simbiose, que aumentam com a fertilização de $\mathrm{P}$, incluem o teor total de nitrogênio na planta, a fitomassa seca, o número de nódulos, a fitomassa dos nódulos (Pereira \& Bliss, 1987) e a atividade da nitrogenase (Al-Niemi et al., 1997). Legumes são particularmente afetados pela baixa disponibilidade de fósforo; por serem culturas tipicamente desenvolvidas em simbioses, apresentam maior requerimento de 
fósforo que plantas desenvolvidas com nitrogênio mineral (Aggarwal et al., 1997; AlNiemi et al., 1997).

O gasto com carbono no sistema radicular é a limitação primária para o crescimento de plantas de feijão comum em solos com baixa disponibilidade de fósforo (Nielsen et al., 1998). A atividade do sistema radicular apresenta um custo metabólico significante em termos de recursos, especialmente, quando a planta está sob estresse edáfico (Lynch \& Brown, 2001). Cerca de 40\% do total disponível de carbono é empregado no sistema radicular de plantas de feijoeiro comum, quando associadas com micorrizas (Nielsen et al., 1998).

A taxa de crescimento da parte aérea do feijoeiro decresce conforme intensifica a deficiência de fósforo. Plantas sem fósforo apresentaram-se menores e com coloração verde mais escuro (Cakmak et al., 1994) porque as expansões celulares e foliares são mais retardadas que a formação de cloroplastos e clorofila (Marschner, 2002).

Em feijão, do total de carboidratos da planta, 22,7\% é alocado para o sistema radicular quando a planta está em condições de deficiência de fósforo, enquanto que 15,7\% é direcionado para as raízes, quando a planta está bem suprida desse elemento (Marschner, 2002). Em plantas sem fósforo, a concentração de sacarose não é alterada nas folhas primárias, embora decresça nas folhas trifoliadas, enquanto a concentração de amido é elevada (Cakmak et al., 1994).

\subsection{Sistema radicular}

\subsubsection{Arquitetura do sistema radicular}

A exploração do solo é definida pelo crescimento do sistema radicular (Nielsen et al., 1998; Yan et al.; 1995; Williamson et al., 2001; Fisher et al., 2002). O crescimento e o desenvolvimento do sistema radicular são geralmente avaliados em função do aumento de massa e volume (Jesko, 1994), são dinâmicos e extremamente dependentes das condições do solo (Taiz \& Zeiger, 2003). O sistema radicular é composto de várias raízes, com propriedades distintas (Nielsen et al., 1998; Nielsen et al., 2001).

Um sistema radicular eficiente é aquele que otimiza a relação entre quantidade de recursos adquiridos (inclusive P) com os empregados para sua obtenção. Quando 
nitrogênio, fósforo ou água são fatores limitantes, ocorre um aumento da proporção de recursos alocados para o desenvolvimento radicular (Still \& Scheible, 1998). Modificações no substrato afetam, através de mecanismos desconhecidos, a condutância estomática, a taxa de expansão foliar e, conseqüentemente, a taxa de fixação de carbono (Jackson, 1993).

O tamanho e a distribuição da parte aérea influenciam o sistema radicular através do suprimento de carbono. Além disso, mecanismos de controle interno, relacionados com a força de dreno da parte aérea, podem exercer grande influência no desenvolvimento radicular (Jackson, 1993). O custo relativo, em termos do uso de carbono para a construção de uma nova raiz, e o benefício de aquisição de nutriente podem diferir em função de características do solo (Campbell et al., 1962; Gross et al., 1993). Robinson (1996a; 1996b) verificou que muitos modelos consideram que o carbono pode ser utilizado como sinal para que as plantas apresentem comportamento fisiológico alternativo. Outra hipótese, é que a arquitetura do sistema radicular seria definida através da ação coordenada de processos nos eixos radiculares, ou mesmo, em diferentes partes do sistema radicular.

A arquitetura do sistema radicular é fundamental para a aquisição de recurso no solo (Yan et al., 1995; Miller, 1998). Sua definição é muito complexa, por envolver vários aspectos, como taxa de crescimento, ramificação, orientação e longevidade dos diferentes tipos de raiz (Bonser et al., 1996).

O desenvolvimento espacial do sistema radicular determina a habilidade da planta em explorar os recursos que estão mal distribuídos (Williamson et al., 2001; Fisher et al., 2002; Ge et al., 2000; Lynch \& Brown, 2001; Rubio et al., 2001; LópezBucio et al., 2002; Fan et al., 2003).

As características das raízes podem alterar a relação do crescimento da raiz e do seu custo de carbono. Modelos de simulação (Figura 5) sugerem que a arquitetura do sistema radicular possa alterar o custo, em termos de carbono, da exploração do solo e definir a capacidade de competição do sistema radicular (Ge et al., 2000; Rubio et al., 2001; Fan et al., 2003). 


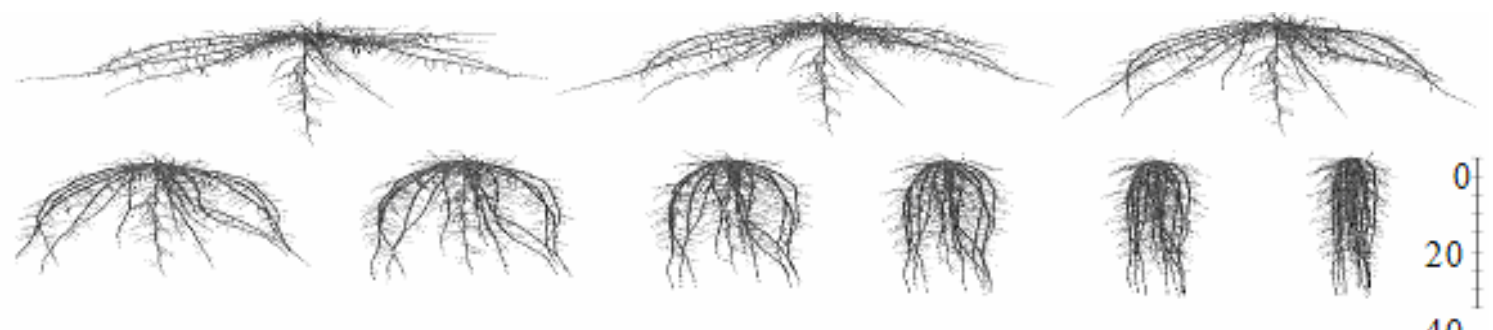

Figura 5 - Variação do ângulo da raiz basal do sistema radicular do feijoeiro comum. Sistema radicular simulado pelo programa computacional SimRoot (escala: cm). A variação depende da plasticidade do genótipo e da disponibilidade de fósforo no solo (Ge et al., 2000)

A raiz formada na fase embriogênica é denominada raiz primária. A partir dessa, podem ocorrer ramificações, diversas vezes. Essas raízes são, geralmente, formadas acropetamente ao periciclo, embora o primórdio radicular também poder ser organizado a partir da endoderme, do córtex, ou mesmo de determinado tipo de parênquima (Jesko, 1994). A formação de raízes laterais na raiz principal, basal ou adventícia, constitui um importante componente para a definição da arquitetura do sistema radicular, pois definem a maior parte da fitomassa e, do comprimento do sistema radicular (Lynch \& Brown, 2001). Além das raízes laterais, podem ocorrer raízes adventícias, que são formadas em circunstâncias especiais. Ou seja, fora da normal seqüência temporal ou em locais incomuns (Barlow, 1994).

A resposta da arquitetura radicular à disponibilidade de fósforo parece ser extremamente específica (Bates \& Lynch, 1999; Williamson et al., 2001; López-Bucio et al., 2002), influenciando o ângulo de crescimento das raízes basais em relação à gravidade (Bonser et al., 1996; Liao et al., 2001).

Estudos relativos à arquitetura do sistema radicular são úteis na quantificação da eficiência fisiológica de sistemas radiculares contrastantes, fornecendo ferramentas para investigação de mecanismos específicos, viabilizando a formação de variedades cultivadas com maior eficiência no uso de fósforo (Nielsen et al., 1998). 


\subsubsection{Plasticidade do sistema radicular}

A capacidade de adaptação do sistema radicular, através de mudanças morfológicas e fisilógicas, às condições do meio ambiente é dada pela plasticidade fenotípica (Robinson, 1994; Lynch \& Brown, 1997; López-Bucio et al., 2002). As plantas que apresentam maior plasticidade são mais competitivas (Ge et al., 2000; Rubio et al., 2001; Fan et al., 2003; Rubio et al., 2003).

O mecanismo que define o acúmulo de fotoassimilados, ou seja, de fitomassa seca, ainda não foi suficientemente elucidado, entretanto, o padrão básico dessa distribuição é determinado geneticamente para várias espécies (Jesko, 1994). Existem muitas evidências sobre a interdependência entre raiz e parte aérea. Um exemplo é a relação entre taxa de crescimento da parte aérea e a taxa de absorção de P (Salisbury \& Ross, 1992).

A relação entre raiz e parte aérea é determinada pela diferença fisiológica entre esses órgãos. Raízes geralmente se desenvolvem no escuro, portanto, são dependentes de fotoassimilados. As partes aéreas, por sua vez, são dependentes da absorção de água e nutrientes pelas raízes. As atividades da parte aérea, bem como do sistema radicular, são decisivas para definir a massa e o volume de ambos. As relações entre esses órgãos são coordenadas e reguladas por fitohormônios, com destaque para auxinas e citocininas. O balanço entre parte aérea e sistema radicular é dinâmico e sujeito a modificações (Jesko, 1994). A comprovada correlação entre parte aérea e sistema radicular, no entanto, não especifica o que é causa ou conseqüência (Salisbury \& Ross, 1992).

O efeito de estresses nutricionais sobre a alocação de carbono, geralmente, proporciona aumento do sistema radicular, ou seja, da capacidade de absorção (Friend et al., 1994). O P apresenta baixa mobilidade no solo (Bonser et al., 1996) e, freqüentemente, limita a produtividade (López-Bucio et al., 2002). A resposta do sistema radicular à baixa disponibilidade de fósforo é bem específica (Bates \& Lynch, 1996; Williamson et al., 2001), e ocorre através da plasticidade de diversas características do sistema radicular, tal como proliferação de raízes em sítios onde ocorre maior disponibilidade de P (Duncan \& Ohlrogge, 1958; Drew \& Saker, 1978; Bonser et al., 1996). 
As raízes de Poácea, proliferadas em regiões mais férteis do substrato, são finas e apresentam elevação em diversas características, tais como comprimento específico, número de raízes laterais e sublaterais, comprimento do eixo radicular principal, comprimento médio da raiz principal e comprimento de raiz secundária em relação ao comprimento do eixo principal (Larigaurderie \& Richards, 1994).

\subsubsection{Gravitropismo}

Gravitropismo é a resposta específica de crescimento em relação à força da gravidade (Lynch \& Brown, 2001). Faz com que uma planta colocada na horizontal, curve sua parte aérea para cima e seu sistema radicular para baixo (Salisbury \& Ross, 1992; Taiz \& Zeiger, 2003). Raízes geralmente apresentam gravitropismo positivo (Salisbury \& Ross, 1992; Jesko, 1994; Taiz \& Zeiger, 2003). As raízes primárias são, geralmente, orientadas mais verticalmente que as secundárias, enquanto raízes terciárias ou de ordem superior, podem se desenvolver em quase todas as direções (Salisbury \& Ross, 1992).

A resposta à mudança de gravidade pode ser divida em três fases: percepção, tradução e resposta (Salisbury \& Ross, 1992; Jesko, 1994; Taiz \& Zeiger, 2003). A percepção ou a detecção inicial da gravidade parece ocorrer na coifa, nos últimos milímetros da raiz. A resposta - uma alteração no padrão de crescimento, que conduz à curvatura para baixo - ocorre após a coifa, na zona de alongamento que, como sugere o nome, é a zona onde ocorre o alongamento das células (Evans et al., 1986).

A percepção da gravidade é dada pela movimentação de amiloplastos. Esses possuem dois ou mais grânulos de amido e se localizam nas células da coifa da raiz (Salisbury \& Ross, 1992; Jesko, 1994; Taiz \& Zeiger, 2003). Conforme o posicionamento da raiz em relação à gravidade, estes se sedimentam sobre os retículos endoplasmáticos, localizados na parte basal da célula, proporcionando a liberação de cálcio. O cálcio se liga à uma proteína denominada calmodolina. Quando desprovida de cálcio, a calmodolina é inativa. A cálcio-calmodolina, originária dessa ligação, ativa as bombas de cálcio e auxina localizadas nas partes basais da membrana celular, proporcionando aumento na concentração de auxina e cálcio. A elevada concentração de 
auxina inibe o crescimento dessa região da raiz, provocando a curvatura da mesma (Evans et al., 1986).

Existem controvérsias com relação à fase de tradução, processo intermediário e mais desconhecido que envolve algum tipo de comunicação entre a coifa e a zona de alongamento. A natureza exata da interação dessas duas regiões ainda está sendo decifrada (Evans et al., 1986). Nos anos 70, acreditava-se que o geotropismo positivo das raízes era decorrente do acúmulo de $\mathrm{ABA}$ na parte basal da raiz, que inibia o alongamento dessa região. Mais recentemente, a hipótese da auxina agindo em conjunto com íons $\mathrm{Ca}^{2+}$ tem sido mais aceita (Salisbury \& Ross, 1992; Jesko, 1994). Quando a raiz está na posição horizontal, ocorre migração de $\mathrm{Ca}^{2+}$ para a coifa. O acúmulo desse íon na parte basal estimula a movimentação diferencial e basípeta da auxina para a zona de alongamento. Ao longo do estímulo da gravidade, o balanço entre o movimento acrópeto da auxina, como estimulador do crescimento, e o movimento basípeto do ABA, que inibe o crescimento, é alterado. Como conseqüência, ocorre o crescimento longitudinal e assimétrico entre os lados inferior e superior (Jesko, 1994).

Existe, ainda, outra hipótese, onde o sinal que desencadeia a resposta seria elétrico, ou eletroquímico, e não hormonal (Evans et al., 1986; Salisbury \& Ross, 1992; Taiz \& Zeiger, 2003). Essa considera uma corrente elétrica simétrica ao longo do sistema radicular, quando esse está na posição vertical. Quando as raízes são colocadas na horizontal, essa corrente passa a ser assimétrica. Há evidências da participação do fluxo de $\mathrm{H}^{+}$na formação dessa corrente elétrica. (Evans et al., 1986; Salisbury \& Ross, 1992). O fluxo de $\mathrm{H}^{+}$estaria refletindo o fluxo de cálcio para a parte basal da coifa, para manutenção do equilíbrio de cargas (Evans et al., 1986).

Assim como para fototropismo, o gravitropismo apresenta denominações em decorrência do ângulo de crescimento em relação à força da gravidade. Exemplos disso seriam o ortogravitropismo (crescimento vertical), o diagravitropismo (crescimento horizontal) e o plagiogravitropismo (crescimento em ângulos entre O e $180^{\circ}$ ) (Salisbury \& Ross, 1992).

Dada a heterogeneidade da distribuição do fósforo no solo, a orientação do sistema radicular em relação à gravidade deve definir a aquisição de fósforo quando sua 
disponibilidade é limitada. Plantas de ervilha, soja e feijão apresentaram menores ângulos de crescimento das raízes basais na ausência de P (Bonser et al., 1996).

Raízes basais do feijoeiro comum exibem ampla variabilidade genética para a resposta gravitrotópica em função da disponibilidade de fósforo. Alguns genótipos não respondem ao $\mathrm{P}$, alguns respondem com raízes basais mais superficiais (Liao et al., 2001) e um número reduzido apresenta raízes mais profundas (Bonser et al., 1996). Essas raízes apresentaram variação do ângulo de crescimento entre $75^{\circ}$ e crescimento quase horizontal. O efeito da disponibilidade de fósforo no crescimento das raízes basais é evidente desde a emergência (Lynch \& Brown, 2001).

Estudos realizados com modelo de simulação geométrica (SimRoot) sugerem que, quando a distribuição de fósforo no substrato é uniforme, sistemas radiculares mais superficiais exploram maior volume de solo por unidade de fitomassa, que sistemas radiculares mais profundos. Por apresentarem raízes basais mais dispersas e sistemas radiculares mais superficiais, esta arquitetura resulta em menor competição entre raízes. Quando o fósforo se concentra na superfície do solo, as simulações mostraram que ocorre maior aquisição deste, através de sistemas radiculares mais superficiais (Ge et al., 2000; Lynch \& Brown, 2001). Esses resultados são coerentes aos encontrados por Bonser et al. (1996) e Liao et al. (2001).

Uma hipótese para a explicação do efeito do P no gravitropismo seria a redução da síntese de amido nas raízes, decorrente da limitação de Pi, causando um efeito de redução do número ou do tamanho de grânulos de amido, que proporcionaria a redução no ângulo de crescimento das raízes (Bonser et al., 1996).

\subsubsection{Custo metabólico do sistema radicular e deficiência de fósforo}

Respiração e fosforilação oxidativa são as principais fontes de energia, tanto para o crescimento, quanto para a manutenção dos tecidos radiculares em condição fisiológica ativa. Considerável parte da energia, proveniente da respiração do sistema radicular, é empregada por células da raiz no crescimento e no transporte de íons e solutos contra o gradiente de concentração (Gasparikóvá, 1994). 
A taxa de respiração do sistema radicular, ao longo do tempo, está relacionada às taxas fotossintética e à translocação de açúcares para as raízes (Salisbury \& Ross, 1992). Esse processo é regulado tanto por condições do meio ambiente, como pelo requerimento de energia, agentes redutores e intermediários (Gasparikóvá, 1994).

O gasto total da respiração do sistema radicular tem sido dividido em três componentes: para o crescimento de tecidos novos, para a manutenção de tecidos preexistentes e para a absorção e o transporte de íons (Johnson, 1990; Nielsen et al., 1998; Fan et al., 2003). Segundo Fan et al. (2003), a respiração de partes basais e médias de raízes seminais é preferencialmente envolvida com a manutenção dos tecidos, porque, nessas regiões, o crescimento já foi estacionado. No entanto, a respiração do ápice radicular está relacionada às funções de crescimento, absorção e transporte de íons. Conforme as raízes crescem e ficam mais velhas, os gastos de carbono passam a ter maior relevância para a manutenção do tecido (Fan et al., 2003).

A respiração do sistema radicular consume cerca de duas vezes mais carbono em plantas sob baixo teor de fósforo, quando comparada com a respiração de plantas que não sofreram esse estresse. A fração estimada da respiração total do sistema radicular, usada para a manutenção do sistema radicular, é maior em plantas sob baixo fósforo (Nielsen et al., 1998). Esse processo não é influenciado por umidade ou concentração de $\mathrm{CO}_{2}$ do solo (Fan et al., 2003).

Nielsen et al. (1998) acompanharam, semanalmente, o balanço de carbono do feijoeiro comum durante a fase vegetativa. Os autores verificaram que as plantas sob deficiência de fósforo, durante o crescimento, empregam maior fração de carbono na respiração do sistema radicular, que plantas que não foram submetidas a esse estresse. $\mathrm{O}$ aumento na respiração foi atribuído à elevação da relação entre raiz e parte aérea. O valor da respiração específica é reduzido, ao longo do tempo, nas plantas que se desenvolveram sob baixa disponibilidade de $\mathrm{P}$, em função da redução do gasto com crescimento e absorção de íons.

As raízes consomem uma significante fração do carboidrato disponível na planta, especialmente, em condições em que o fósforo é limitado. Dependendo da espécie, chega a consumir mais de $50 \%$ da quantidade de carbono fixado. Dessa, uma 
significante porção é empregada na manutenção das células do sistema radicular (Nielsen et al., 1998, Nielsen et al., 2001; Fan et al., 2003).

\subsection{Capacitância}

O sistema radicular é uma estrutura complexa, tipicamente composta por centenas de eixos radiculares que variam com relação ao desenvolvimento, à fisiologia e à morfologia. Embora o sistema radicular seja de fundamental importância, esse órgão tem sido pouco estudado em relação à parte área (Heeraman et al., 1997). Esse fato, provavelmente, é decorrente da dificuldade de seu estudo, uma vez que seu desenvolvimento ocorre no solo, restringindo observações diretas. Em condições de campo, o tamanho do sistema radicular tem sido ignorado em função da dificuldade de realização de medições (Choupek et al., 1999).

Choupek (1972) investigou a capacitância elétrica das raízes como uma maneira não destrutiva de estimar a área superficial de raízes de milho, girassol (Helianthus annuus L.), aveia (Avena sativa L.), cebola (Allium cepa L.) e nabo (Brassica napus L.). Foi verificada uma correlação significante $\left(r^{2}=0,43\right.$ a 0,92$)$ entre a capacitância elétrica e a área superficial das raízes, em vegetais que apresentam grande relação entre área explorada e as raízes (milho, girassol, aveia e cevada). No entanto, essa relação não foi verificada para espécies que possuem grande fitomassa radicular distribuída em uma área pequena, como, por exemplo, o nabo. Choupek (1977) demonstrou que células da raiz conferem considerável resistência à passagem de corrente elétrica pelo sistema radicular. Foi verificado que a determinação da capacitância elétrica é dependente tanto da área superficial, como do conteúdo celular.

Em trabalhos com capacitância, Campbell et al. (1962) desenvolveram um método para medições de pastagens in situ. $\mathrm{O}$ instrumento consiste em um medidor de capacitância, o qual plantas introduzidas no sistema induziriam uma mudança no valor de capacitância elétrica medida. O tamanho dessa mudança está relacionado à quantidade de pastagem. O instrumento indicava cerca de $90 \%$ da variação na produção de pastagem, tanto em termos de fitomassa seca, como em termos de fitomassa fresca. Esse método foi empregado com instrumentos adaptados por diversos autores. 
Kendall et al. (1982) avaliaram o uso de capacitância elétrica para estimar a fitomassa seca do trevo vermelho. A metodologia, no entanto, mostrou-se eficiente somente no início e no final da estação de crescimento de alfafa. Os autores sugerem que fatores edáficos, como variação do conteúdo de água solo ao redor das raízes, possam afetar a precisão da medida durante parte do crescimento.

No passado, as medidas de capacitância elétrica no campo eram trabalhosas, em função do grande tamanho das baterias e dos medidores. Além disso, a técnica empregada para medir a capacitância consumia tempo, porque requeria o uso de uma agulha hipodérmica inserida na haste da planta. O desenvolvimento de um medidor manual de capacitância, que é leve, pode se tornar uma eficiente ferramenta para que pesquisadores quantifiquem a massa radicular in situ. Caso seja associado a um método mais rápido para obtenção da medida de capacitância, tal artifício poderia ser rotineiramente empregado na seleção de genótipos, em que as características do sistema fossem relevantes. Com a vantagem do método da capacitância poder avaliar o sistema radicular efetivamente ativo, tendo em vista que não considera tecidos já lignificados (Van Beem et al., 1998).

Dalton (1995) sugere que a capacitância elétrica seja utilizada para determinação do tamanho do sistema radicular uma vez que, verificou grande correlação entre valores de capacitância elétrica e de fitomassa seca de raízes de tomateiro (Lycopersicon esculentum Mill.). Além disso, verificou que quando o teor da água no solo é elevado, sua influência sobre as determinações dos valores de capacitância é mínima. O mesmo autor observou o efeito do posicionamento do eletrodo nos valores de capacitância, e verificou que, conforme é aumentada a distância do eletrodo em relação à coroa, o valor da capacitância da raiz é reduzido. 


\section{MATERIAL E MÉTODOS}

\subsection{Material vegetal}

A planta estudada foi o feijoeiro comum, variedade cultivada Pérola e progênies formadas a partir do cruzamento realizado no CIAT, Colômbia, entre os genótipos G19839 e G2333. O genótipo G19839 apresenta enraizamento adventício baixo ou tardio, e é considerado bem adaptado à condição de baixa disponibilidade de fósforo (Lynch \& Beebe, 1995). O genótipo G2333 é caracterizado por elevada plasticidade do sistema radicular em resposta à baixa disponibilidade de fósforo, considerado, portanto, um genótipo tolerante a baixos teores de fósforo no solo (Gepts \& Fernández, 1982).

\subsection{Local de instalação e condução dos experimentos}

Os experimentos realizados com a variedade cultivada Pérola foram instalados no Horto Experimental do Departamento de Ciências Biológicas da Escola Superior de Agricultura “Luiz de Queiroz” (ESALQ/USP), município de Piracicaba, SP.

Experimentos com diferentes genótipos foram realizados no Departamento de Horticultura da Universidade da Pensilvânia, Estados Unidos, nos meses de março a junho de 2003. Sob a supervisão do Prof. Dr. Jonathan Lynch, esse trabalho é consistente com a linha de pesquisa do supervisor, que já tem elaborado hipóteses para justificar o efeito da disponibilidade de fósforo no substrato no crescimento e no desenvolvimento do sistema radicular do feijoeiro comum.

A Tabela 2 apresenta a descrição resumida dos experimentos que foram realizados e o local onde foram realizados. 
Tabela 2. Descrição dos experimentos

\begin{tabular}{clc}
\hline Experimento & \multicolumn{1}{c}{ Descrição } & Local \\
\hline I & calibração do medidor BK Precision 810 B para determinação & Brasil \\
& de capacitância de plantas de feijão comum em solução & \\
& nutritiva \\
II & efeito do fósforo no desenvolvimento do sistema radicular e da & Brasil \\
& parte aérea do feijoeiro comum e calibração para determinação & \\
& de capacitância em substrato sólido & \\
III & seleção entre seis genótipos para o enraizamento adventício do & EUA \\
& feijoeiro comum em diferentes teores de fósforo no substrato & \\
& (areia) & \\
IV & seleção entre nove genótipos para o enraizamento adventício & EUA \\
& do feijoeiro comum em diferentes teores de fósforo no & \\
& substrato (areia e vermiculita) & \\
V & efeito do teor e da distribuição de fósforo no substrato e de & EUA \\
& cinco genótipos no desenvolvimento do feijoeiro comum & \\
VI & efeito do fósforo estratificado no substrato na arquitetura do & Brasil \\
& sistema radicular do feijoeiro comum & \\
\hline
\end{tabular}

Os experimentos I, II e VI foram instalados no Horto Experimental do Departamento de Ciências Biológicas da Escola Superior de Agricultura "Luiz de Queiroz” (ESALQ/USP), município de Piracicaba, SP (latitude sul: 2242’30’”; longitude oeste: 47³8’00'; altitude: 546 m).

Os experimentos III, IV e V foram realizados no Departamento de Horticultura da Universidade da Pensilvânia (University Park, PA, USA - 4085N; 7703W), Estados Unidos. 


\subsection{Capacitância e atributos da planta}

A relação funcional entre a área radicular e o valor de capacitância, obtido com medidor portátil (BK Precision - modelo 810 B), foi estabelecida por Dalton (1995). O valor de capacitância é dado pela seguinte equação:

$$
C=\frac{\lambda \cdot A}{4 \cdot \pi \cdot r \cdot \ln \left(\frac{R}{r}\right)}
$$

em que $\lambda$ se refere à constante dielétrica, $\mathrm{r}$ ao raio interno $(\mathrm{cm})$ do cilindro (xilema) condutor, R ao raio externo médio $(\mathrm{cm})$ do sistema radicular do feijoeiro comum, e A, a superfície $\left(\mathrm{cm}^{2}\right)$ radicular de absorção, definida por:

$$
A=2 . \pi \cdot R \cdot L
$$

em que L se refere ao comprimento $(\mathrm{cm})$ médio do sistema radicular do feijoeiro comum.

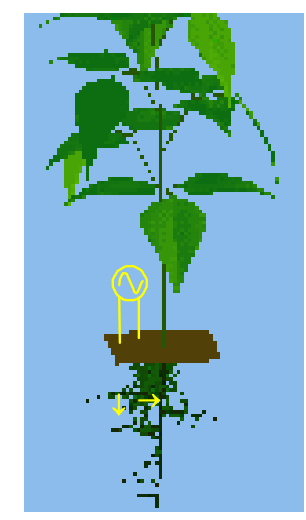

b

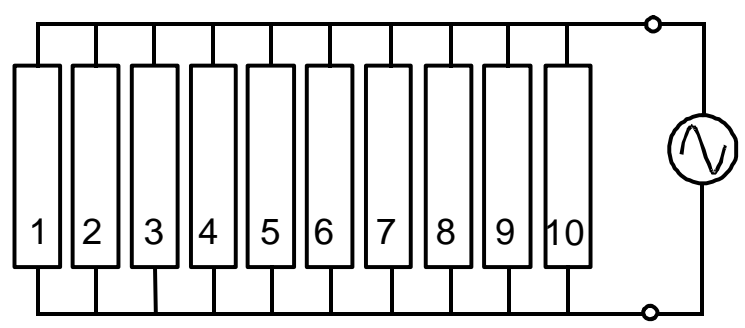

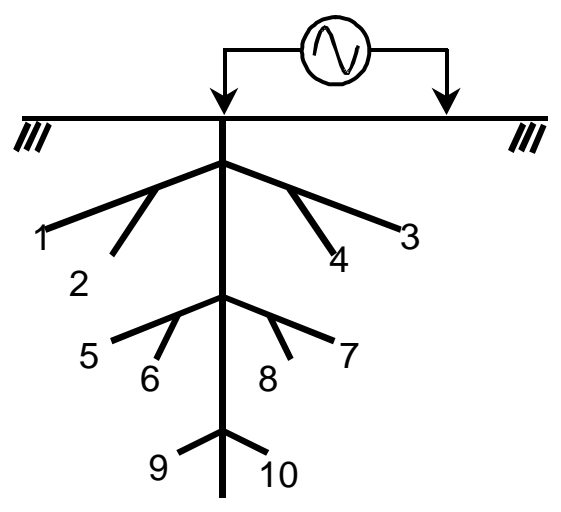

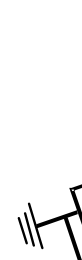

H
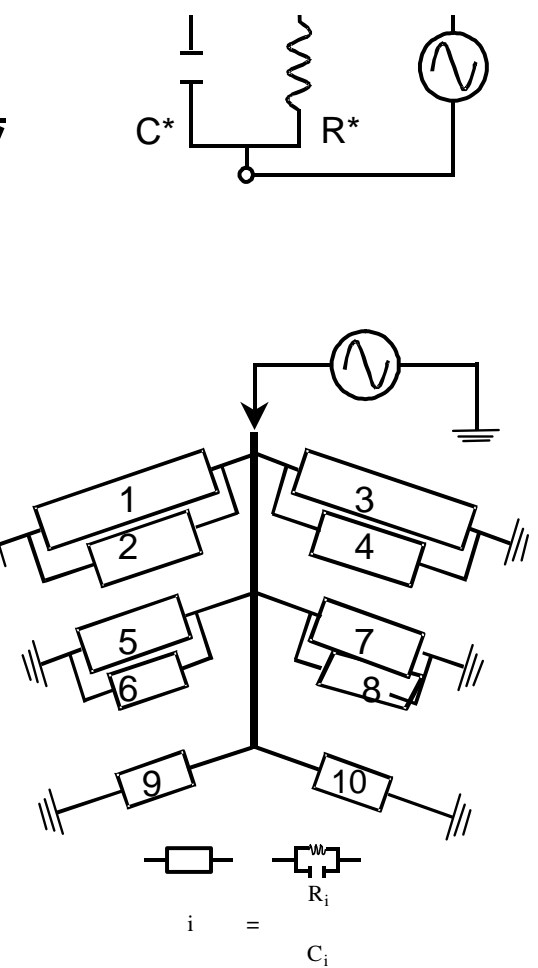

Figura 6 - Representação esquemática do medidor portátil de capacitância BK Precision (modelo 810 B) 
O esquema geral da determinação de valores de capacitâncias é ilustrado na Figura 6. A área de cada elemento é diretamente proporcional à capacitância. O valor encontrado com o uso do medidor de capacitância estima a área superficial do sistema radicular, ou seja, a somatória das capacitâncias de cada eixo radicular.

\subsection{Experimento I: calibração do medidor BK Precision 810 B para determinação de capacitância de plantas de feijão (feijoeiro comum) em solução nutritiva}

As sementes do feijoeiro comum, variedade cultivada 'Pérola', foram colocadas em rolos de papel filtro umedecido e inseridas em câmara úmida para germinação. Quando as plântulas atingiram cerca de $10 \mathrm{~cm}$ de altura total (considerando o sistema radicular), foram transferidas para vasos plásticos de 3 litros, com tampas, contendo solução nutritiva. As tampas apresentavam quatro orifícios, um deles foi utilizado para entrada do sistema de aeração, enquanto nos demais foram colocadas plantas (Figura 7), o que resultou em uma densidade de três plantas por vaso (área de 0,22 $\mathrm{m}^{2}$ ), e um total de 21 plantas.

As plantas foram mantidas em casa-de-vegetação, e a quantidade de solução nutritiva nos vasos foi mantida constante. Quando as plantas atingiram o estádio fenológico $\mathrm{V}_{4}$, segundo descrição da escala fenológica proposta por Gepts \& Fernándes (1982) e Dourado Neto \& Fancelli (2000), o valor de capacitância foi determinado com o medidor BK Precision 810 B. Para isso, foi inserida uma haste de cobre $(50 \mathrm{~cm}$ de comprimento e $1 \mathrm{~cm}$ de diâmetro) na solução nutritiva, na qual foi conectado o eletrodo positivo. Foram realizadas medidas com o eletrodo negativo, posicionado na planta, em duas estaturas distintas: no colo e a cinco cm desse. Para manter o distanciamento entre o colo e o eletrodo na haste da planta, foi fixada uma barra plástica com $5 \mathrm{~cm}$ de comprimento junto ao eletrodo, de forma que, em todas as medidas, o posicionamento do eletrodo fosse mantido. A Figura 7 ilustra o procedimento de determinação da capacitância.

Foram realizadas determinações da capacitância com o instrumento ajustado a 20 $\mu \mathrm{F}$ e a $200 \mathrm{nF}$, o que equivale, respectivamente, às freqüências de 81,9 Hz e 819 Hz. O 
medidor de capacitância teve o seu valor de leitura ajustado a zero, antes que fosse colocado o eletrodo na planta, com o intuito de eliminar o efeito da capacitância referente ao solo e à haste de metal. As medidas foram determinadas depois da completa estabilização do valor de leitura. Em seguida, as plantas foram retiradas dos vasos, as hastes foram cortadas na altura do colo, e a fitomassa fresca do sistema radicular foi medida.

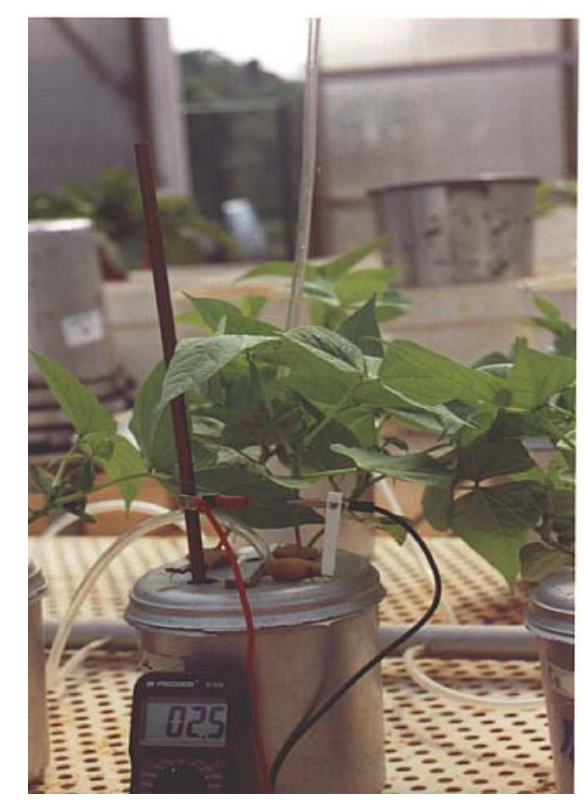

Figura 7 - Determinação de capacitância com uso do medidor BK Precision 810 B, em plantas de feijão cultivadas em solução nutritiva. O eletrodo positivo está conectado à haste de cobre, enquanto o negativo, a $5 \mathrm{~cm}$ do colo da planta

Com os dados obtidos, foi estabelecida uma relação entre os valores de capacitância (200 nF) e fitomassa fresca radicular.

\subsection{Experimento II: efeito do fósforo no desenvolvimento do sistema radicular e da parte aérea do feijoeiro comum e calibração para determinação de capacitância em substrato sólido}

O delineamento experimental foi em blocos ao acaso, em esquema de parcelas, com dois tratamentos (dois teores de fósforo no solo) e 21 repetições, totalizando 42 plantas. 
O feijoeiro comum, variedade cultivada Pérola foi utilizado como material vegetal. Como substrato, utilizou-se terra procedente de um solo da Estação Experimental Anhembi, pertencente ao Departamento de Genética (ESALQ/USP), em função do baixo teor de fósforo $\left(3 \mathrm{mg} \cdot \mathrm{dm}^{-3}\right)$ apresentado, conforme demonstrado na análise química do solo (Tabelas 3 a 5).

Tabela 3. Análise química de solo: $\mathrm{pH}$ em $\mathrm{CaCl}_{2}(\mathrm{pH})$, teor de matéria orgânica (MO, g. $\left.\mathrm{dm}^{-3}\right)$, fósforo $\left(\mathrm{P}, \mathrm{mg} \cdot \mathrm{dm}^{-3}\right)$, enxofre $\left(\mathrm{S}, \mathrm{mg} \cdot \mathrm{dm}^{-3}\right)$, potássio $(\mathrm{K}$, $\left.\mathrm{mmol}_{\mathrm{c} \cdot} \cdot \mathrm{dm}^{-3}\right)$, Ca $\left(\mathrm{Ca}, \mathrm{mmol}_{\mathrm{c}} \cdot \mathrm{dm}^{-3}\right)$, magnésio $\left(\mathrm{Mg}, \mathrm{mmol}_{\mathrm{c}} \cdot \mathrm{dm}^{-3}\right)$, alumínio $\left(\mathrm{Al}, \mathrm{mmol}_{\mathrm{c}} \cdot \mathrm{dm}^{-3}\right)$, hidrogênio e alumínio $\left(\mathrm{H}+\mathrm{Al}, \mathrm{mmol}_{\mathrm{c} \cdot} \cdot \mathrm{dm}^{-3}\right)$, soma de bases $\left(\mathrm{SB}, \mathrm{mmol}_{\mathrm{c} \cdot} \cdot \mathrm{dm}^{-3}\right)$, capacidade de troca catiônica $\left(\mathrm{T}, \mathrm{mmol}_{\mathrm{c}} \cdot \mathrm{dm}^{-3}\right)$, saturação de bases (V, \%), saturação por alumínio (m, \%)

\begin{tabular}{ccccccccccccc}
\hline $\mathrm{pH}$ & $\mathrm{MO}$ & $\mathrm{P}$ & $\mathrm{S}^{1}$ & $\mathrm{~K}$ & $\mathrm{Ca}$ & $\mathrm{Mg}$ & $\mathrm{Al}$ & $\mathrm{H}+\mathrm{Al}$ & $\mathrm{SB}$ & $\mathrm{T}$ & $\mathrm{V}$ & $\mathrm{m}$ \\
\hline 4,4 & 17 & 3 & 27 & 0,6 & 5 & 3 & 5 & 31 & 8,6 & 39,6 & 22 & 37 \\
\hline
\end{tabular}

${ }^{1} \mathrm{~S}: \mathrm{Ca}\left(\mathrm{H}_{2} \mathrm{PO}_{4}\right)_{2} 0,01 \mathrm{~mol} \cdot \mathrm{L}^{-1}(10 \mathrm{~mL}$ TFSA $/ 25 \mathrm{~mL})$

Tabela 4. Análise de química do solo: micronutrientes (mg. $\mathrm{dm}^{-3}$ )

\begin{tabular}{ccccc}
\hline $\mathrm{B}^{1}$ & $\mathrm{Cu}^{1}$ & $\mathrm{Fe}^{1}$ & $\mathrm{Mn}^{1}$ & $\mathrm{Zn}^{1}$ \\
\hline 0,15 & 0,6 & 59 & 4,1 & 0,4 \\
\hline
\end{tabular}

${ }^{1}$ Método empregado: $\mathrm{Cu}$, Fe, Zn - DTPA - TEA; B = BaCl2.2H2O 0,125\% microondas (10 mL TFSA/20 $\mathrm{mL} \mathrm{BaCl} 20,125 \%)$

Tabela 5. Análise granulométrica do solo

\begin{tabular}{cccc}
\hline $\operatorname{Areia}^{1}(\%)$ & Silte $^{1}(\%)$ & Argila (\%) & Classe Textural \\
\hline 90 & 4 & 6 & Arenosa \\
\hline${ }^{1}$ Método do densímetro. Classe de diâmetro: (i) areia: 0,05 a 2 mm; (ii) silte: 0,002 a 0,05 mm; (iii) argila: \\
inferior a 0,002 mm. Classe de textura arenosa: até 14\% de argila.
\end{tabular}

A terra foi peneirada e pesada para a realização de correções na fertilidade, segundo sugestão de Dourado Neto \& Fancelli (2000).

Como tratamentos, foram considerados dois teores de fósforo no solo. No tratamento 1, as plantas foram cultivadas em substrato com correção de todos os 
elementos nutrientes, inclusive o fósforo, que foi elevado para $25 \mathrm{mg} \cdot \mathrm{dm}^{-3}$. No tratamento 2, as plantas foram cultivadas em substratos com os nutrientes corrigidos da mesma forma, com exceção do fósforo, que foi mantido em $3 \mathrm{mg} \cdot \mathrm{dm}^{-3}$.

Foi feita a calagem para se atingir $\mathrm{V}=50 \%$, através da seguinte equação:

$$
N C=\frac{(V d-V a) \cdot T \cdot \rho \cdot Z \cdot M_{M g} \cdot M_{C a}}{\operatorname{Re} \cdot\left(T_{M g} \cdot M_{C a}+T_{C a} \cdot M_{M g}\right)}
$$

Em que NC se refere à necessidade de calagem $\left(\mathrm{kg} \cdot \mathrm{ha}^{-1}\right)$; $\mathrm{Vd}$ à saturação de bases desejada $\left(\mathrm{mmol}_{\mathrm{c}} \cdot \mathrm{mmol}_{\mathrm{c}}^{-1}\right)$; Va à saturação de bases atual $\left(\mathrm{mmol}_{\mathrm{c}} \cdot \mathrm{mmol}_{\mathrm{c}}{ }^{-1}\right)$; $\mathrm{T}$ à capacidade de troca catiônica $\left(\mathrm{mmol}_{\mathrm{c}} \cdot 100 \mathrm{~g}^{-1}\right) ; \rho$ à massa específica do solo $\left(\mathrm{g} \cdot \mathrm{cm}^{-3}\right)$; Z à profundidade de correção $(\mathrm{cm}) ; \mathrm{M}_{\mathrm{Mg}}$ à massa de um $\mathrm{mmol}_{\mathrm{c}}$ de $_{\mathrm{Mg}^{+2}}\left(12 \mathrm{mg} \cdot \mathrm{mmol}_{\mathrm{C}}{ }^{-1}\right)$; $\mathrm{M}_{\mathrm{Ca}}$ à massa de um $\mathrm{mmol}_{\mathrm{C}}$ de $\mathrm{Ca}^{+2}\left(20 \mathrm{mg}^{\mathrm{m}} \mathrm{mmol}_{\mathrm{C}}{ }^{-1}\right)$; Re à reatividade do calcário $\left(\mathrm{kg} \mathrm{kg}^{-1}\right) ; \mathrm{T}_{\mathrm{Mg}}$ ao teor de $\mathrm{Mg}^{+2}$ no calcário $\left(\mathrm{kg} \mathrm{kg}^{-1}\right) ; \mathrm{T}_{\mathrm{Ca}}$ ao teor de cálcio no calcário $\left(\mathrm{kg} \cdot \mathrm{kg}^{-1}\right)$.

A terra foi irrigada e mantida em casa-de-vegetação, acondicionada em lona plástica, para a reação do calcário. A terra foi pesada, visando atingir a massa específica de 1,44 g.cm $\mathrm{cm}^{-3}$ em todos os vasos. Esse valor foi atribuído em função da textura arenosa apresentada na análise do solo.

Todos os cálculos referentes à adubação de semeadura levaram em consideração a padronização da massa específica, mantendo a proporção de $20 \mathrm{~kg}$ ha ${ }^{-1}$ de nitrogênio, 50 kg.ha- ${ }^{-1}$ de potássio, 30 kg.ha- ${ }^{-1}$ de enxofre, 1 kg.ha ${ }^{-1}$ de boro, 3 kg.ha ${ }^{-1}$ de zinco.

Para a definição da dose adequada de fósforo e obtenção do teor final de 25 mg.dm ${ }^{-3}$ deste elemento foi utilizada a seguinte equação:

$$
N F=\frac{9 \cdot(P d-P a) \cdot Z}{400 \cdot E f . T f}
$$

em que NF se refere à necessidade de fertilizante fosfatado (kg.ha- $\left.{ }^{-1}\right)$; Pd à quantidade de fósforo desejada $\left(\mathrm{mg} \cdot \mathrm{dm}^{-3}\right)$; Pa à quantidade de fósforo atual $\left(\mathrm{mg}^{-\mathrm{dm}^{-3}}\right)$; $\mathrm{Z}$, à profundidade de correção (cm); Ef à eficiência do fertilizante ( $\left.\mathrm{kg}^{\mathrm{kg}} \mathrm{kg}^{-1}\right)$; Tf ao teor de fósforo no fertilizante $\left(\mathrm{kg}_{\mathrm{kg}} \mathrm{kg}^{-1}\right)$. 
Foram colocadas, em cada vaso, seis sementes de feijoeiro comum, para a densidade final de três plantas por vaso. A distribuição das plantas no vaso foi em linha, com espaçamento de 0,105 m entre plantas, na linha, e de 0,40 m entre as linhas, o que resultou em uma densidade de 9,55 plantas por metro linear e 238.853 plantas.ha $^{-1}$. Este valor está dentro da faixa de 180.000 a 240.000 plantas. ha ${ }^{-1}$, amplitude que tem sido empregada pela maioria dos produtores. Durante todo o período do experimento, os vasos foram irrigados para a manutenção do solo na capacidade de campo.

A padronização da avaliação do experimento foi feita em função do estádio de desenvolvimento fenológico $\left(\mathrm{V}_{5}\right)$, e não em função do tempo. Optou-se por esse critério por ser mais extrapolável e mais adequado para a comparação entre o tratamento sem fósforo e com fósforo. As determinações de capacitância foram realizadas com o solo na capacidade de campo (Chloupek, 1977).

Neste experimento, onde foram utilizados $20 \mathrm{~kg} \cdot \mathrm{ha}^{-1}$ de nitrogênio, as plantas que não receberam fertilização com fósforo não apresentaram nodulação (Figuras 8 e 9), resultando em plantas com deficiência em nitrogênio. Como o objetivo deste estudo concentra-se no efeito do fósforo, o experimento foi interrompido e repetido com uma dose maior desse elemento: 60 kg.ha ${ }^{-1}$ de nitrogênio.

Sendo assim, foram feitas as seguintes determinações: capacitância, fitomassa fresca e de matéria seca do sistema radicular e da parte aérea do feijoeiro comum.

Foram realizadas determinações de capacitância com o eletrodo negativo posicionado na haste da planta a $5 \mathrm{~cm}$ de altura do colo, altura em que no Experimento I, apresentou maior correlação entre os valores de capacitância e quantidade de fitomassa fresca do sistema radicular. As determinações foram feitas, conforme descrito no experimento I, a $200 \mathrm{nF}$ (freqüência de $819 \mathrm{~Hz}$ ), assim que o valor de leitura estabilizou.

As raízes foram lavadas e as fitomassas frescas do sistema radicular e da parte aérea foram medidas. A parte aérea foi colocada em sacos de papel, em estufa de ventilação forçada com temperatura de $60^{\circ} \mathrm{C}$, onde permaneceram até umidade constante para determinação da fitomassa seca. 


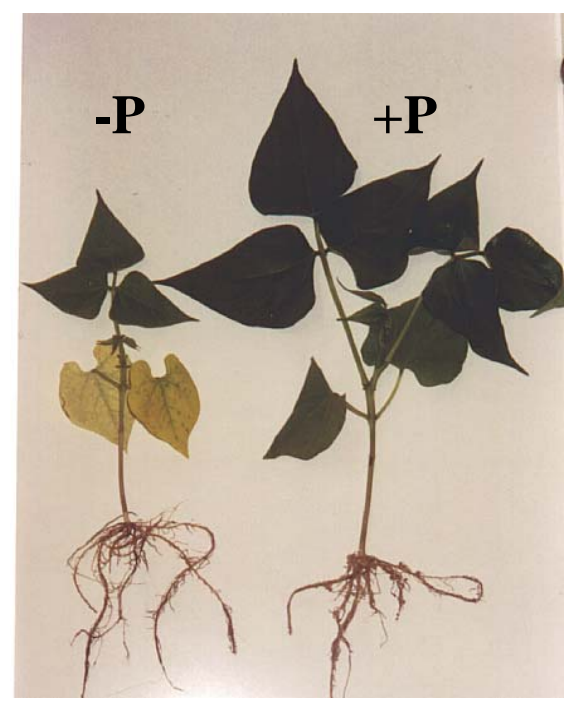

Figura 8 - Feijoeiro comum com (+P) e sem (-P) adição de fósforo

A fitomassa fresca do sistema radicular foi determinada e, posteriormente, colocada em recipientes plásticos, contendo etanol (70\%), para evitar a desidratação e a alteração do valor de área.

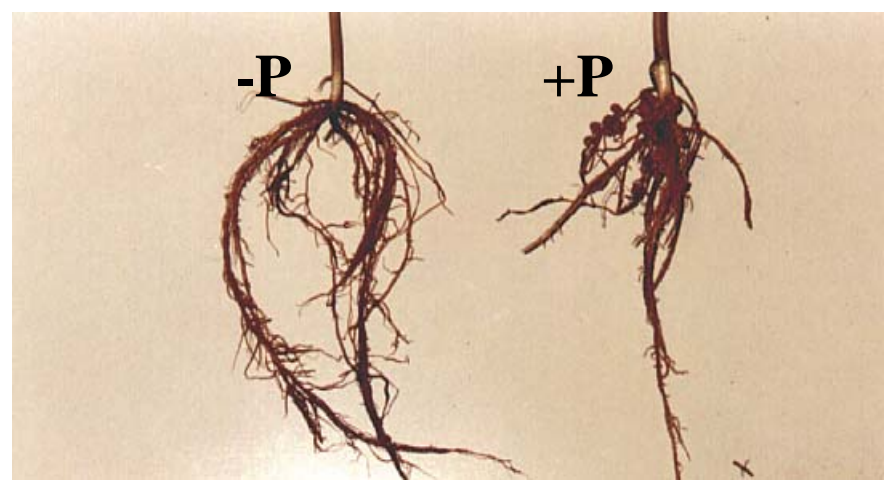

Figura 9 - Sistema radicular do feijoeiro comum com (+P) e sem (-P) nodulação

O comprimento das raízes foi determinado com o uso do Delta T Scan (Figura 10). O tamanho atingido pelas raízes impediu que essas fossem copiadas com auxílio de scanner em uma única etapa, sem sobreposição. Depois de determinado o comprimento, as raízes foram transferidas para sacos de papel e colocadas em estufa de ventilação forçada a $60^{\circ} \mathrm{C}$, para medida da fitomassa seca. 


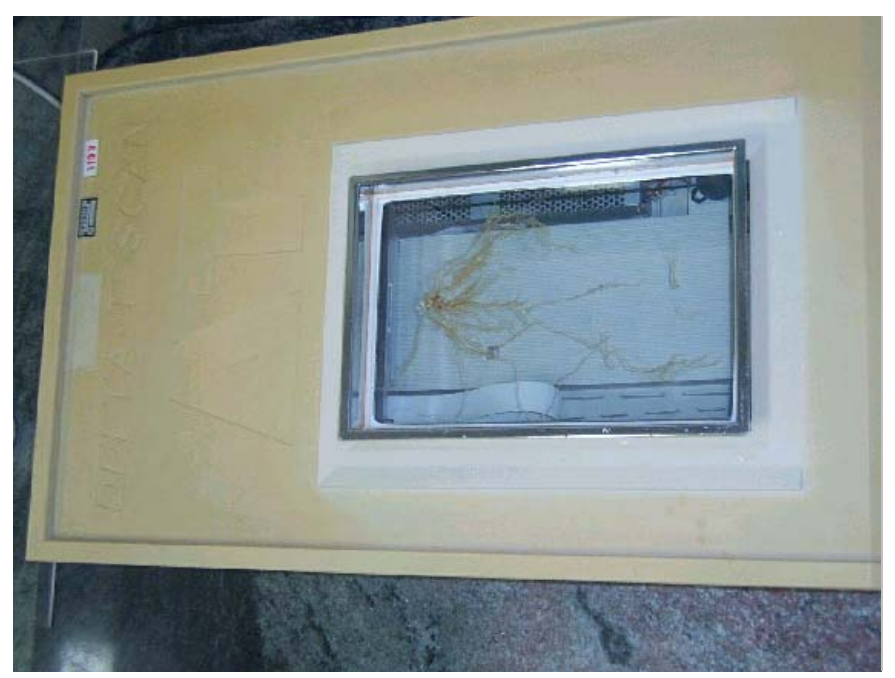

Figura 10 - Detalhe do equipamento (Delta T Scan, Delta T), durante determinação da área radicular do feijoeiro comum

Os dados obtidos foram submetidos à análise estatística através do uso do teste de Tukey.

\subsection{Experimento III: seleção entre seis genótipos para o enraizamento adventício do feijoeiro comum em diferentes teores de fósforo no substrato (areia)}

O desenho experimental foi em blocos ao acaso, em esquema de parcelas subdivididas, sendo as parcelas, o teor e a localização de fósforo no substrato, e as subparcelas, seis genótipos de feijoeiro comum. Como se tratou de um experimento preliminar, não houve repetições.

Foram utilizados os genótipos G11, G17, G21, G35 e G53, os quais são provenientes da nona geração (F9) do cruzamento entre G2333 (alta plasticidade em resposta a baixa disponibilidade de fósforo) e G19839 (elevado número de raízes adventícias). Esses genótipos foram selecionados a partir de estudos prévios, em condições de hidroponia $\left(\mathrm{Ochoa}^{2}\right)$, em função do enraizamento adventício e da plasticidade radicular, apresentados em condições de baixa disponibilidade de fósforo.

\footnotetext{
${ }^{2}$ OCHOA, I. Comunicação pessoal, 2003
} 
Foi incluído o genótipo brasileiro (Pérola), empregado neste projeto para a melhor caracterização de seu sistema radicular, totalizando seis genótipos.

O experimento foi instalado em casa-de-vegetação, com sistema de refrigeração e aquecimento, mantendo a temperatura máxima, ao longo do dia, em $32^{\circ} \mathrm{C}$, e a noturna, em $20^{\circ} \mathrm{C}$, durante todo o período experimental. Utilizou-se, como substrato, 9,5 litros de areia por vaso (pote plástico).

Foi colocada uma tela plástica $(2 \mathrm{~mm}) 17 \mathrm{~cm}$ da base do pote, de forma que a terra foi estratificada em duas camadas. A camada superficial de 1,5 litros, com $6 \mathrm{~cm}$ de profundidade, e a camada basal com 8 litros e $17 \mathrm{~cm}$ de profundidade.

Água e nutrientes foram fornecidos em quantidades ótimas. Para tal, foi utilizada solução nutritiva para cultivo em areia (adaptada por Lynch, 1995) (Tabela 6). Como fonte de fósforo, empregou-se Al-P (fósforo sólido tamponado), na proporção de 1\% (volume/volume) do substrato, e que, segundo Lynch et al. (1992), proporciona maior controle da disponibilidade de fósforo às plantas. De acordo com a disponibilidade de fósforo, foram realizados dois tratamentos: (1) alto teor de P (150 a $200 \mu \mathrm{M}$ Al-P 1,5\% v/v no pote todo), e (2) baixo teor de P (20 $\mu \mathrm{M}$ na camada superficial e 0,8 $\mu \mathrm{M} 1,5 \% \mathrm{v} / \mathrm{v}$ na camada basal do vaso).

As plantas foram coletadas aos 21 dias após a germinação. O sistema radicular foi dividido em três grupos: raízes adventícias, superficiais e profundas. As raízes superficiais incluem as desenvolvidas na camada superficial do vaso, e as profundas as que atravessaram a tela e se desenvolveram na base do vaso.

Foram feitas as seguintes determinações: número e fitomassa seca de raízes adventícias, e fitomassa seca de raízes superficiais e de raízes profundas.

Somente as raízes adventícias foram contadas. Todas as raízes, adventícias, superficiais e profundas, foram secas em estufa a $60^{\circ} \mathrm{C}$ por 72 horas, para a determinação da fitomassa seca. 
Tabela 6. Composição da solução nutritiva. Os tratamentos dose alta (Da) e baixa (Db) diferem na quantidade de solução 3. Utilizou-se em Da 1 mM e em Db 0,001 mM na água de irrigação (Lynch et al., 1992)

\begin{tabular}{|c|c|c|c|c|c|}
\hline \multirow[t]{2}{*}{ Solução } & \multirow[t]{2}{*}{ Composto } & \multirow[t]{2}{*}{ MW } & \multicolumn{2}{|c|}{$\begin{array}{l}\text { Concentração na } \\
\text { Solução }\end{array}$} & \multirow{2}{*}{$\begin{array}{c}\text { Concentração na } \\
\text { água de irrigação } \\
\mathrm{mM}\end{array}$} \\
\hline & & & $\mathrm{mM}$ & $m L . L^{-1}$ & \\
\hline \multicolumn{6}{|l|}{1} \\
\hline & $\mathrm{KNO}_{3}$ & 101,1 & 1500 & 151,65 & 1,5 \\
\hline & $\mathrm{Ca}\left(\mathrm{NO}_{3}\right)_{2} \cdot \mathrm{H}_{2} \mathrm{O}$ & 236,15 & 1200 & 283,38 & 1,2 \\
\hline & $\mathrm{NH}_{4} \mathrm{NO}_{3}$ & 80,04 & 400 & 32,02 & 0,4 \\
\hline & $\mathrm{MgCl}_{2} \cdot 6 \mathrm{H}_{2} \mathrm{O}$ & 203,31 & 25 & 5,08 & 0,025 \\
\hline & Fe-EDTA(Na) & 367,1 & 5 & 1,84 & 0,005 \\
\hline \multicolumn{6}{|l|}{2} \\
\hline & $\mathrm{MgSO}_{4} .7 \mathrm{H}_{2} \mathrm{O}$ & 246,48 & 500 & 123,24 & 0,5 \\
\hline & $\mathrm{K}_{2} \mathrm{SO}_{4}$ & 174,26 & 300 & 52,28 & 0,3 \\
\hline & $\left(\mathrm{NH}_{4}\right) \mathrm{SO}_{4}$ & 132,4 & 300 & 39,72 & 0,3 \\
\hline & $\mathrm{MnSO}_{4} \cdot \mathrm{H}_{2} \mathrm{O}$ & 169,01 & 1,5 & 0,25 & 0,0015 \\
\hline & $\mathrm{ZnSO}_{4} \cdot 7 \mathrm{H}_{2} \mathrm{O}$ & 287,55 & 1,5 & 0,43 & 0,0015 \\
\hline & $\mathrm{CuSO}_{4} \cdot 5 \mathrm{H}_{2} \mathrm{O}$ & 249,71 & 0,5 & 0,12 & 0,0005 \\
\hline & $\left(\mathrm{NH}_{4}\right)_{6} \mathrm{Mo}_{7} \mathrm{O}_{24} \cdot 4 \mathrm{H}_{2} \mathrm{O}$ & 1235,86 & 0,15 & 0,19 & 0,00015 \\
\hline & $\mathrm{Na}_{2} \mathrm{~B}_{4} \mathrm{O}_{7} \cdot 10 \mathrm{H}_{2} \mathrm{O}$ & 381,37 & 0,5 & 0,19 & 0,0005 \\
\hline \multicolumn{6}{|l|}{3} \\
\hline & $\mathrm{KH}_{2} \mathrm{PO}_{4}$ & 136,09 & 1000 & 136,09 & $1(\mathrm{Da})$ \\
\hline & & & & & $0,001(\mathrm{Db})$ \\
\hline
\end{tabular}




\subsection{Experimento IV: seleção entre nove genótipos para o enraizamento adventício do feijoeiro comum em diferentes teores de fósforo no substrato (areia e vermiculita)}

O desenho experimental foi em blocos ao acaso, em esquema de parcelas subdivididas, sendo as parcelas, o teor e a localização de fósforo no substrato, e as subparcelas, nove genótipos de feijoeiro comum. Como se tratou de um experimento preliminar ao experimento $\mathrm{V}$, e havia um baixo número de sementes disponíveis, não houve repetições.

Foram utilizados os genótipos G6, G11, G17, G23, G31, G52, G57 e G61, provenientes da nona geração (F9) do cruzamento entre G2333 e G19839.

Assim como no experimento III, o substrato utilizado foi uma mistura de areia e vermiculita (1:1). Esse também foi estratificado em duas camadas, com uso de tela plástica (2 mm), sendo a superior com 1,5 L e a inferior com $8 \mathrm{~L}$ de substrato. Água e nutrientes foram fornecidos através de solução nutritiva (adaptada por Lynch, 1995) (Tabela 6).

O experimento foi realizado em casa-de-vegetação com sistema de refrigeração e aquecimento e temperatura diurna mantida em $32^{\circ} \mathrm{C}$, e noturna em $20^{\circ} \mathrm{C}$.

Foram realizados dois tratamentos levando em consideração a disponibilidade de P: (i) alto teor de P (150 a $200 \mu \mathrm{M}$ Al-P 1,5\% v/v no vaso todo), e (ii) baixo teor de P (20 $\mu \mathrm{M}$ na camada superior e $0,8 \mu \mathrm{M} 1,5 \% \mathrm{v} / \mathrm{v}$ na camada inferior do pote).

As plantas foram coletadas com 21 e 36 dias após a germinação. O sistema radicular foi dividido em três grupos: raízes adventícias, superficiais e profundas. Foram avaliados os seguintes atributos: número e comprimento de raízes adventícias, fitomassa seca de raízes superficiais (aqui, incluindo as raízes adventícias), de raízes profundas e de parte aérea.

Somente as raízes adventícias foram contadas, coradas com 0,19 g.L $\mathrm{L}^{-1}$ de vermelho neutro (Sigma Chemical Co, St. Louis, MO, USA) para serem copiadas com auxílio de scanner. As imagens foram analisadas com o software WinRhizo (Regente, Canadá) para a determinação do comprimento. Em seguida, todos os grupos de raízes e a 
parte aérea foram secos em estufa de ventilação forçada a $60^{\circ} \mathrm{C}$ por 72 horas, para a determinação da fitomassa seca do sistema radicular e da parte aérea.

Com os dados obtidos, foi feita uma seleção preliminar dos genótipos a serem utilizados no experimento $\mathrm{V}$.

Foram estabelecidas relações entre a porcentagem de fitomassa seca de raízes superficiais (incluindo raízes adventícias) e fitomassa seca total do sistema radicular; entre fitomassa seca de raízes profundas e fitomassa seca total do sistema radicular; e entre fitomassa seca do sistema radicular e fitomassa seca total (sistema radicular e parte aérea).

\subsection{Experimento V: efeito do teor e da distribuição de fósforo no substrato e de cinco genótipos no desenvolvimento do feijoeiro comum}

O delineamento experimental empregado foi blocos ao acaso, em esquema de parcelas subdivididas, sendo as parcelas, teor e localização de fósforo no substrato, e as subparcelas, cinco genótipos de feijoeiro comum, com quatro repetições.

O experimento foi instalado em casa-de-vegetação, com sistema de refrigeração e aquecimento, mantendo a temperatura máxima, ao longo do dia, em $32^{\circ} \mathrm{C}$, e a noturna, em $20^{\circ} \mathrm{C}$, durante todo o período experimental.

Conforme respostas observadas nos experimentos preliminares anteriores, foram selecionados cinco genótipos diferentes (linhas de híbridos recombinantes): G6, G11, G21, G31 e G57, por apresentarem respostas contrastantes ao enraizamento adventício, e à plasticidade radicular quando induzidos por baixos níveis de fósforo.

Os níveis de fósforo utilizados foram: dose alta (Da) e dose baixa (Db). Nos vasos com Da foi utilizado o teor de $1 \%$ (v/v) de Al-P a $42 \mu \mathrm{M}$, uniformemente distribuído, enquanto os vasos com $\mathrm{Db}$, com $\mathrm{P}$ estratificado, de acordo com o posicionamento da tela plástica, os teores de $1 \%$ (v/v) de Al-P a $20 \mu \mathrm{M}$ na camada superior e $1 \%(\mathrm{v} / \mathrm{v})$ de Al-P a 1,8 $\mu \mathrm{M}$ na camada inferior do vaso. O elemento fósforo foi fornecido através de fósforo sólido tamponado (Al-P).

Foram usados vasos contendo 9,5 litros de substrato, composto de 50\% de areia e $50 \%$ de vermiculita. Para verificar a superficialidade do sistema radicular, em resposta a 
diferentes níveis de fósforo, foi colocada um tela de plástica $(2 \mathrm{~mm})$ a $6 \mathrm{~cm}$ de profundidade (17 cm da base do pote). Assim, o substrato foi dividido em duas camadas, a superficial (com 1,5 L de substrato) e a basal (com 8 litros de substrato), para se avaliar a proporção do sistema radicular que se desenvolveu em cada camada.

As sementes foram esterilizadas superficialmente com hipoclorito de cloro (10\%) e enxaguadas com água destilada. Foram colocadas em papel azul para germinação (Anchor Paper Co., St. Paul, MN, USA), embebido com solução de $\mathrm{CaSO}_{4} 10 \mathrm{mM}$. Para a germinação, utilizou-se câmara de crescimento a $25^{\circ} \mathrm{C}$, no escuro. Sementes prégerminadas foram colocadas acima da tela plástica, ou seja, a seis $\mathrm{cm}$ de profundidade.

Água e nutrientes, com exceção de fósforo, foram adicionados em níveis ótimos. Foi utilizada solução nutritiva para cultivo em areia, modificada por Lynch et al. (1992) (Tabela 6). O tratamento Da (dose alta de P) inclui a aplicação de fósforo desde o transplantio. Não foi adicionado fósforo na solução nutritiva nos primeiros dez dias após a emergência. As soluções de irrigação dos dois tratamentos (Da e $\mathrm{Db}$ ) foram formuladas da seguinte maneira: Da: $1 \mathrm{~mL} . \mathrm{L}^{-1}$ da solução nutritiva $1 ; 1 \mathrm{~mL} . \mathrm{L}^{-1}$ da solução nutritiva 2 e 1 mL. $L^{-1}$ da solução nutritiva 3 . Db: $1 \mathrm{~mL} \cdot \mathrm{L}^{-1}$ da solução nutritiva 1 ; 1 mL. $L^{-1}$ da solução nutritiva 2 e 0,001 mL. $L^{-1}$ da solução nutritiva 3 (Tabela 6).

Foram feitas as seguintes determinações: respiração radicular; capacitância, número, comprimento e fitomassa seca de raízes adventícias; comprimento e fitomassa seca de raízes superficiais e de raízes profundas; e fitomassa seca da parte aérea.

A respiração radicular foi medida aos 14 e aos 28 dias após a emergência (DAE) com utilização do equipamento LI-6400 (Licor Co, Nebraska, USA). Para tal, foi colocada uma câmara de acrílico para vedar a superfície do vaso (Figura 11).

Os vasos foram irrigados e a capacitância foi medida (Figura 12) imediatamente antes da coleta, realizada aos 14, 21 e 28 DAE. As demais determinações também foram feitas aos 14, 21 e 28 dias. Os valores de capacitância foram mensurados com o medidor de capacitância BK 810C, a 20 nF, o que equivale à freqüência de 81,9Hz. O medidor de capacitância teve o seu valor de leitura ajustado a zero, antes que fosse colocado o eletrodo na planta, com o intuito de eliminar o efeito da capacitância referente ao solo e 
à haste de metal. Os valores de capacitância foram determinados depois da completa estabilização do valor de leitura.

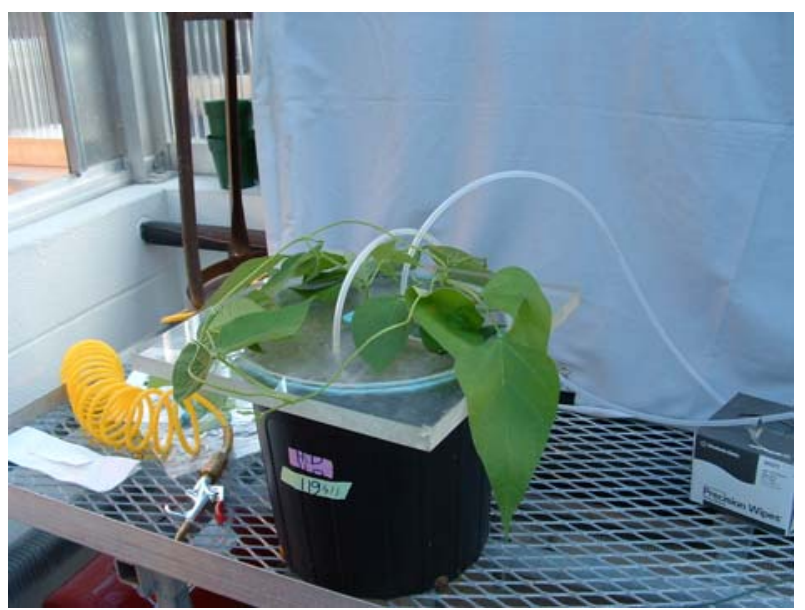

Figura 11 - Vaso utilizado para determinação da respiração radicular

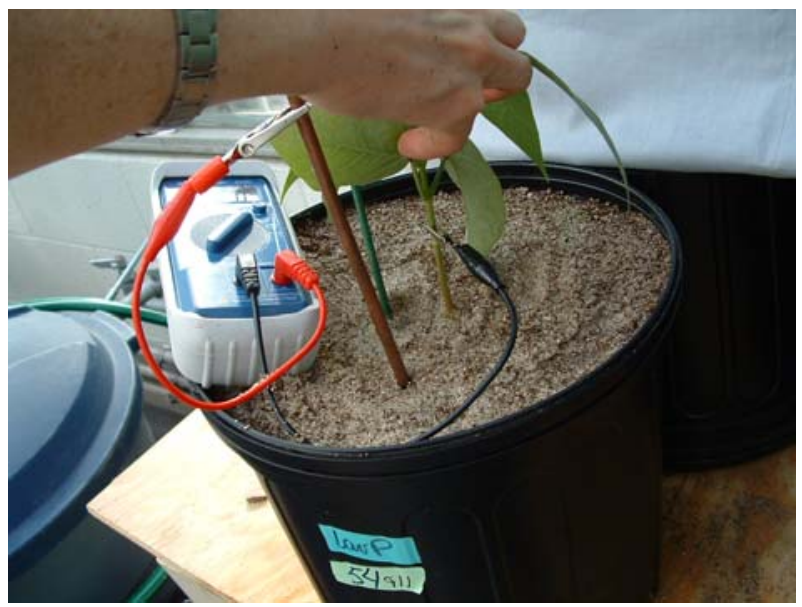

Figura 12 - Medidor de capacitância

Como nos experimentos preliminares, o sistema radicular foi separado da parte aérea, que foi cortada na altura do colo. Em seguida, foi lavado com água destilada e dividido em três grupos: raízes adventícias, raízes superficiais, e raízes profundas. Considerou-se raízes superficiais as desenvolvidas na camada de 0 a 6 cm de profundidade, ou seja, acima da tela plástica, e raízes profundas, as que se desenvolveram abaixo desta. O número de raízes adventícias foi contado. As raízes foram coradas com 0,19 g.L L $^{-1}$ Neutral Red (Sigma Chemical Co, St. Louis, MO, USA) antes que fossem copiadas com auxílio de scanner. As imagens digitais foram analisadas 
com o software WinRhizo (Regent Instruments, Quebec, Canadá). Em seguida, as raízes e a parte aérea foram secas em estufa a $60^{\circ} \mathrm{C}$ para determinação da fitomassa seca.

Os dados obtidos foram analisados com o teste de Tukey.

Para cada um dos genótipos avaliados, foram determinadas as correlações entre os valores de capacitância (20 nF) e as seguintes características, aos 14, 21 e 28 DAE: (i) comprimento total do sistema radicular (mm.planta ${ }^{-1}$ ); (ii) fitomassa seca da parte aérea (g.planta ${ }^{-1}$ ); (iii) fitomassa seca total (sistema radicular e parte aérea, g.planta ${ }^{-1}$ ); (iv) fitomassa seca do sistema radicular (g.planta ${ }^{-1}$ ); (v) respiração do sistema radicular (apenas aos 14 e $28 \mathrm{DAE}, \mu \mathrm{CO}_{2} \cdot \mathrm{min}^{-1}$ ).

Também foram determinadas as correlações entre os valores de capacitância (20 $\mathrm{nF}$ ) e os seguintes atributos da planta, considerando-se os valores médios de todos os genótipos, aos 14, 21 e 28 DAE: (i) comprimento total do sistema radicular (mm.planta ${ }^{-1}$ ); (ii) fitomassa seca da parte aérea (g.planta ${ }^{-1}$ ); (iii) fitomassa seca total (sistema radicular e parte aérea, g.planta ${ }^{-1}$ ); (iv) fitomassa seca do sistema radicular (g.planta ${ }^{-1}$ ); e (v) respiração do sistema radicular (apenas aos 14 e 28 DAE).

\subsection{Experimento VI: efeito do fósforo estratificado no substrato no desenvolvimento do feijoeiro comum}

Como substrato, utilizou-se terra procedente de um solo da Estação Experimental Anhembi, pertencente ao Departamento de Genética (ESALQ/USP), em função do baixo teor de fósforo apresentado (3 mg.dm ${ }^{-3}$ ), conforme demonstrado na análise química do solo (Tabela 3).

O desenho experimental empregado foi em blocos ao acaso, em esquema de parcelas, com seis tratamentos (teor e distribuição de P no substrato) e 12 repetições.

Foram realizadas calagem e correção dos teores de nutrientes, a partir de resultados de análise do solo (Tabelas 3 a 5) conforme sugestão de Dourado Neto \& Fancelli (2000) para feijoeiro comum (60 kg.ha ${ }^{-1}$ de nitrogênio, 30 kg.ha-1 de enxofre, 50 kg.ha ${ }^{-1}$ de potássio $-\mathrm{K}_{2} \mathrm{O}, 1 \mathrm{~kg} \cdot \mathrm{ha}^{-1}$ de boro e $3 \mathrm{~kg} \cdot \mathrm{ha}^{-1}$ de zinco).

O teor de fósforo no tratamento sem fósforo não foi alterado. A fertilização foi feita após um mês de incubação do calcário, quando o teor de água na terra era 
desprezível. A terra foi pesada e o fertilizante uniformemente misturado. Em função do teor de areia do solo utilizado, estabeleceu-se o valor de 1,44 como densidade padrão. Foram utilizados vasos com 26,45 litros, ou seja, 38,08 kg de substrato.

Foram estabelecidos seis tratamentos em função do posicionamento do fósforo (P) no substrato: (i) sem adição de P no substrato (P ausente); (ii) P distribuído de forma homogênea no substrato (P completo); (iii) $\mathrm{P}$ adicionado na profundidade de 0 a $5 \mathrm{~cm}$ (P na superfície) em todo o diâmetro do vaso; (iv) P adicionado a uma faixa de $10 \mathrm{~cm}$ de largura, na profundidade de 0 a $5 \mathrm{~cm}$ (P na superfície em faixa); (v) $\mathrm{P}$ adicionado em todo o diâmetro do vaso (P sub-superfície); e (vi) P adicionado a uma faixa de $10 \mathrm{~cm}$ de largura, de 10 a $15 \mathrm{~cm}$ de profundidade (P sub-superfície em faixa).

Foram semeadas seis sementes de feijoeiro comum para a obtenção da densidade final de três plantas por vaso, após o desbaste. A distribuição das plantas no vaso simulou a densidade de 240.000 plantas.ha $^{-1}$. O substrato foi mantido na capacidade de campo.

Foram feitas as seguintes determinações: capacitância, área foliar, número de folhas trifoliadas e primárias, fitomassa seca da parte aérea, número de raízes adventícias, área, diâmetro médio, comprimento e fitomassa seca das raízes desenvolvidas nas camadas de 0-15 e 15-40 cm de profundidade, aos 42 dias após a semeadura. As determinações de assimilação de carbono, transpiração e condutância estomática foram feitas aos 68 dias após a semeadura, durante o enchimento de grãos $\left(\mathrm{R}_{7}\right)$.

A determinação do valor de capacitância foi feita com uso do medidor de capacitância BK Precision 810 B, a 20 F, ou seja, à freqüência de 81,9 Hz. Para tal, foi inserida ao solo uma haste de cobre de $50 \mathrm{~cm}$ de comprimento e $1 \mathrm{~cm}$ de diâmetro, na qual foi colocado o eletrodo positivo. O eletrodo negativo foi colocado na haste da planta a $5 \mathrm{~cm}$ de altura, que em experimento preliminar apresentou maior correlação entre a medida de capacitância e a quantidade de massa do sistema radicular.

Foram coletadas seis plantas de cada tratamento para determinar área foliar, área radicular e fitomassa seca da raiz e da parte aérea. A área foliar $\left(\mathrm{cm}^{2}\right.$.planta $\left.{ }^{-1}\right)$ foi determinada com uso do medidor de área foliar digital (Li 3100, Lincoln, NE, Estados 
Unidos). O estádio fenológico das plantas foi determinado de acordo com Gepts \& Fernández (1982) e Dourado Neto \& Fancelli (2000), e realizada a análise de nutrientes da parte aérea.

As raízes foram lavadas e separadas da parte aérea. O sistema radicular foi mantido em recipientes plásticos contendo álcool 70\% para que não desidratassem e, portanto, não tivessem o valor de área alterado. As raízes foram coradas com 0,19 g.L ${ }^{-1}$ de vermelho neutro (Sigma Chemical Co, St. Louis, MO, EUA) antes de serem copiadas com auxílio de scanner. As imagens digitais foram analisadas com o programa Delta $\mathrm{T}$ SCAN (Delta-T, Devices Ltd, Cambridge, Reino Unido). O sistema radicular e a parte aérea foram mantidos em estufa a $60^{\circ} \mathrm{C}$ por $72 \mathrm{~h}$, para determinação da fitomassa seca da raiz e da parte aérea.

Foram mantidas seis repetições de cada tratamento em casa-de-vegetação até o final do ciclo, para avaliação de características relacionadas à produtividade, como número de vagens, número de sementes por vagem e fitomassa de sementes na ocasião da colheita. Além disso, foi determinado o número de dias até a senescência completa das plantas. 


\section{RESULTADOS E DISCUSSÃO}

\subsection{Experimento I: calibração do medidor BK Precision 810 B para determinação de capacitância no feijoeiro comum em solução nutritiva}

A capacitância foi determinada com uso do medidor BK PRECISION 810 B, em duas freqüências, para definir a mais adequada para ser correlacionada com os valores de fitomassa fresca da planta. Determinações feitas na freqüência de $81,9 \mathrm{~Hz}$ não apresentaram correlação com os valores de fitomassa fresca radicular. Foram testadas duas alturas para o posicionamento do eletrodo na haste da planta, no colo e a $5 \mathrm{~cm}$ desse. Quando esse foi colocado na altura do colo, como sugere Dalton (1995) para plantas de feijão, não foi observada correlação entre valores de massa e de capacitância. Van Beem et al. (1998) também observaram o efeito do posicionamento do eletrodo na planta e obtiveram resultados semelhantes.

As correlações mais elevadas, entre os dados de massa fresca radicular e capacitância, foram obtidas quando as determinações foram feitas na freqüência de 819 $\mathrm{Hz}$, o que resulta em valores de capacitância na escala de $200 \mathrm{nF}$ e, quando o eletrodo foi posicionado a 5 cm do colo da planta. Esses resultados são apresentados na Figura 13.

O coeficiente de correlação, entre fitomassa fresca radicular e capacitância, foi significativo ao nível de significância próximo de 5\%. Esse valor foi inferior ao encontrado (r=0,872) por Dalton (1995), quando correlacionou o valor de capacitância com fitomassa seca radicular, em tomates cultivados em condições de hidroponia. Apesar da baixa correlação obtida entre os dados, o objetivo do experimento preliminar foi atingido, uma vez que, foi estabelecida a freqüência do eletrodo e o posicionamento na planta. 


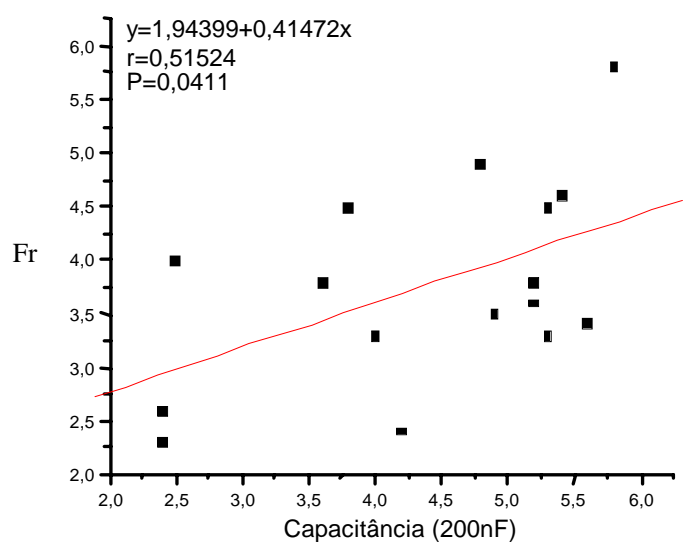

Figura 13 - Relação entre capacitância e a fitomassa fresca radicular (Fr, g.planta ${ }^{-1}$ ) das plantas desenvolvidas em condições de solução nutritiva

\subsection{Experimento II: efeito do fósforo no desenvolvimento do sistema radicular e da parte aérea do feijoeiro comum e calibração para determinação de capacitância em substrato sólido}

Os modelos que simulam a absorção de água não consideram o tipo, a idade ou o tamanho da raiz. O método aqui empregado, no entanto, avalia a parte funcional da raiz, ou seja, a que contribui para o transporte de água e íons, nutrição mineral e fixação de nitrogênio (Dalton, 1995).

Foram obtidos maiores valores de correlação entre fitomassa fresca e capacitância (Figura 15) experimento II do que no experimento I (Figura 13). Os dois experimentos diferiram no estádio fenológico em que foram feitas as determinações de capacitância. No experimento I, realizado em solução nutritiva, as determinações foram feitas no estádio fenológico $V_{4}$. No experimento II, as determinações foram feitas em $R_{5}$ (Gepts \& Fernándes, 1982 citados por Dourado \& Fancelli, 2000).

O efeito da fase de desenvolvimento da planta sobre a determinação de capacitância já havia sido observado por Dalton (1995) e por Van Beem (1998). A Figura 14 ilustra a correlação entre capacitância e fitomassa, para o controle $(+\mathrm{P})$, e a Figura 15, para o tratamento (-P). 

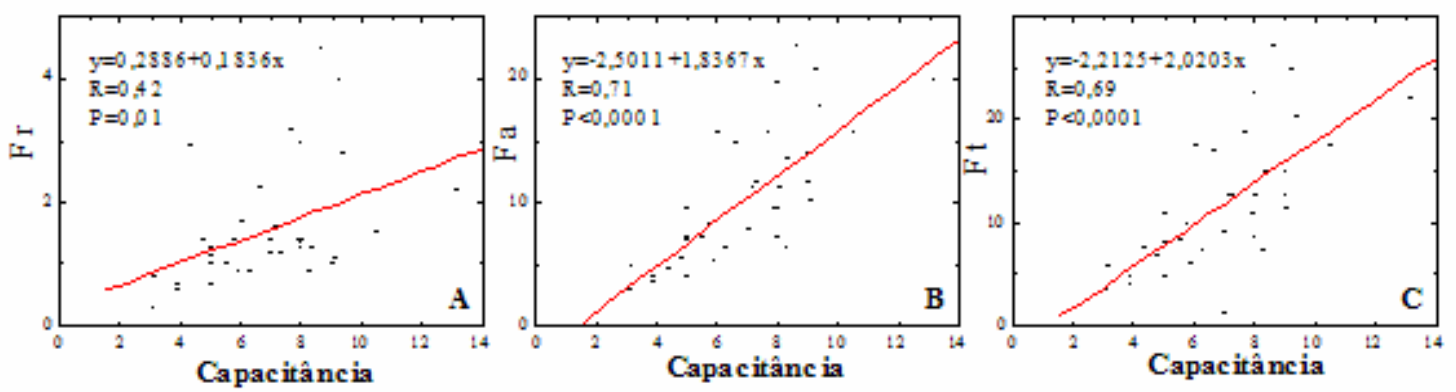

Figura 14 - Correlação entre valores de capacitância (200 nF) e de fitomassa fresca (g.planta ${ }^{-1}$ ) radicular (A), da parte aérea (B), e total (C) de plantas de feijão desenvolvidas em substrato com $P$

Embora o objetivo inicial do trabalho tenha sido analisar o sistema radicular, foram realizadas correlações entre valores de fitomassa fresca da parte aérea e total, com os de capacitância. A observação de coeficientes de correlação elevados, tanto para o tratamento (-P) como para a testemunha ( $+\mathrm{P})$ (Figura 15), sugere que esta metodologia alternativa é promissora para avaliações in situ da fitomassa fresca.
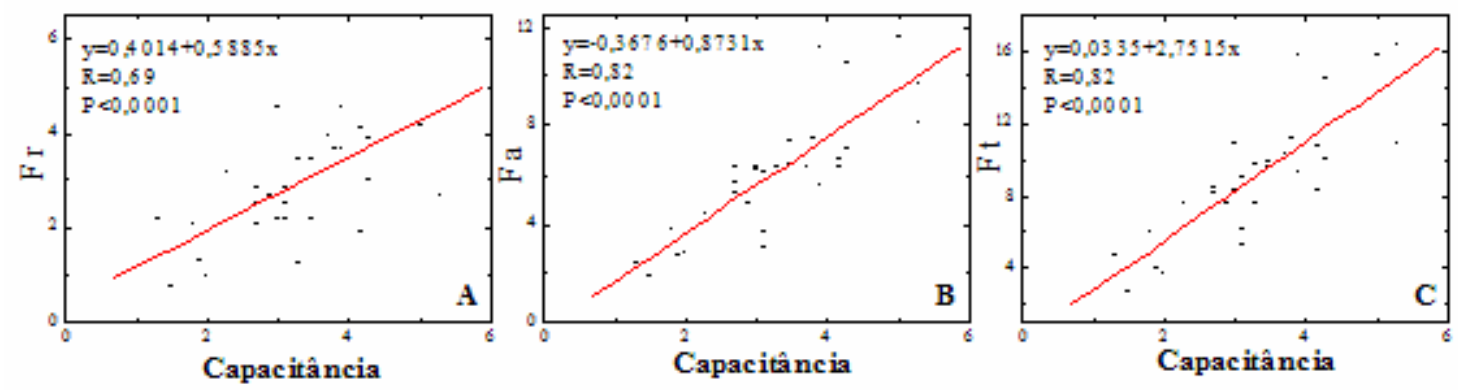

Figura 15 - Correlação entre valores de capacitância e fitomassa fresca (g.planta ${ }^{-1}$ ) radicular (A), da parte aérea (B) e total (C) de plantas de feijão desenvolvidas em substrato desprovido de $\mathrm{P}$

Na Figura 16, as repetições dos dois tratamentos (+P e -P) foram incluídas para determinação da correlação entre capacitância e fitomassa seca da parte aérea (FSa, g.planta $\left.{ }^{-1}\right)(A)$, fitomassa seca radicular (FSr, g.planta ${ }^{-1}$ ), área do sistema radicular (Ar, 
$\mathrm{cm}^{2}$ ) (C) e comprimento radicular (Cr, mm) (D) de plantas de feijão, variedade cultivada Pérola. Os coeficientes de correlação são elevados e o nível de probabilidade é baixo.

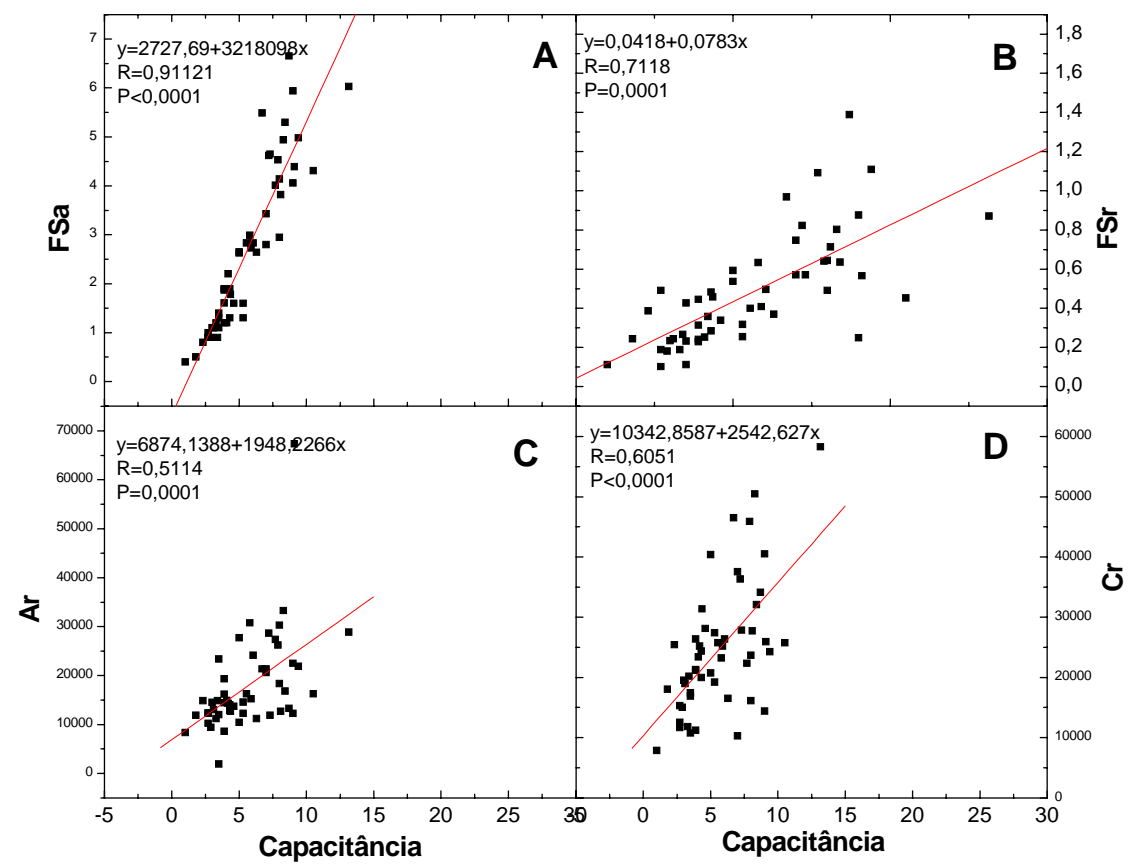

Figura 16 - Correlação entre valores de capacitância (200nF) e fitomassa seca de parte aérea (FSa, g.planta $\left.{ }^{-1}\right)(\mathrm{A})$, fitomassa seca radicular (FSr, g.planta $\left.{ }^{-1}\right)(B)$, área do sistema radicular $\left(\mathrm{Ar}, \mathrm{mm}^{2}\right)(\mathrm{C})$ e comprimento radicular $(\mathrm{C}, \mathrm{mm})(\mathrm{D})$ de plantas de feijão, variedade cultivada Pérola, desenvolvidas com e sem adição de $\mathrm{P}$ ao substrato

Van Beem et al. (1998) verificaram maiores coeficientes de correlação entre os valores de fitomassa fresca radicular, do que quando seca. Esses autores sugerem que esse resultado é vantajoso, uma vez que estão mais próximos das condições in situ. No entanto, os coeficientes de correlação, aqui obtidos, entre capacitância e fitomassa seca (Figura 16) foram superiores aos obtidos com fitomassa fresca (Figura 15). Correlações com fitomassa seca são mais consistentes, uma vez que os valores de fitomassa fresca 
estão sujeitos a variações, na escala de minutos, conforme as condições climáticas, como temperatura e umidade relativa do ar. O argumento de Van Beem et al. (1998), que a correlação com a fitomassa fresca teria a vantagem de ser um parâmetro mais adequado para avaliações das condições in situ, parece desconsiderar que as determinações de capacitância são realizadas nessas condições.

A Figura 16 emprega elevado número de repetições e não determina se existe efeito do tratamento sobre as correlações. Por isso, foram estabelecidas correlações entre capacitância (200nF) e fitomassa seca da parte aérea (FSa, g.planta ${ }^{-1}$ ) (A), fitomassa seca radicular (FSr, g.planta ${ }^{-1}$ ) (B), área do sistema radicular (Ar, mm) (C) e comprimento radicular (C, mm) (D) de plantas de feijão, variedade cultivada Pérola, em +P (Figura 17) e -P (Figura 18).

A correlação entre fitomassa seca total (FST, g.planta ${ }^{-1}$ ) e capacitância é ilustrada na Figura 19 em -P (A) e +P (B) e, incluindo as repetições de ambos (C). Onde se verifica que os coeficientes de correlação são mais elevados em -P. Segundo Dalton (1995), não há dados que expliquem o efeito de sais sobre as propriedades dielétricas do tecido radicular.

A maior concentração de sais, decorrente da adição de P ao substrato, as plantas sem P apresentaram menor acúmulo de fitomassa. O efeito do tamanho da planta, da relação entre raiz e parte aérea, e das diversas alterações fisiológicas apresentadas por plantas deficientes em P (Marschener, 2002) sobre o valor de capacitância é desconhecido.

Além da capacitância, foi verificado o efeito do elemento fósforo no acúmulo de fitomassa fresca. As plantas do tratamento -P apresentaram valores inferiores de fitomassa quando comparadas às plantas do tratamento +P. Isso é evidenciado no atraso do desenvolvimento fenológico. As plantas -P atingiram o estádio $\mathrm{R}_{5}$ nove dias após as $+\mathrm{P}$. Mesmo tendo permanecido nove dias a mais na casa-de-vegetação, as plantas -P apresentaram menores valores de fitomassa fresca no mesmo estádio fenológico. O valor médio de fitomassa fresca total nas plantas em $+\mathrm{P}$ foi de 15,71 g.planta ${ }^{-1}$, enquanto o valor médio das plantas -P foi de 10,28 g.planta ${ }^{-1}$. 


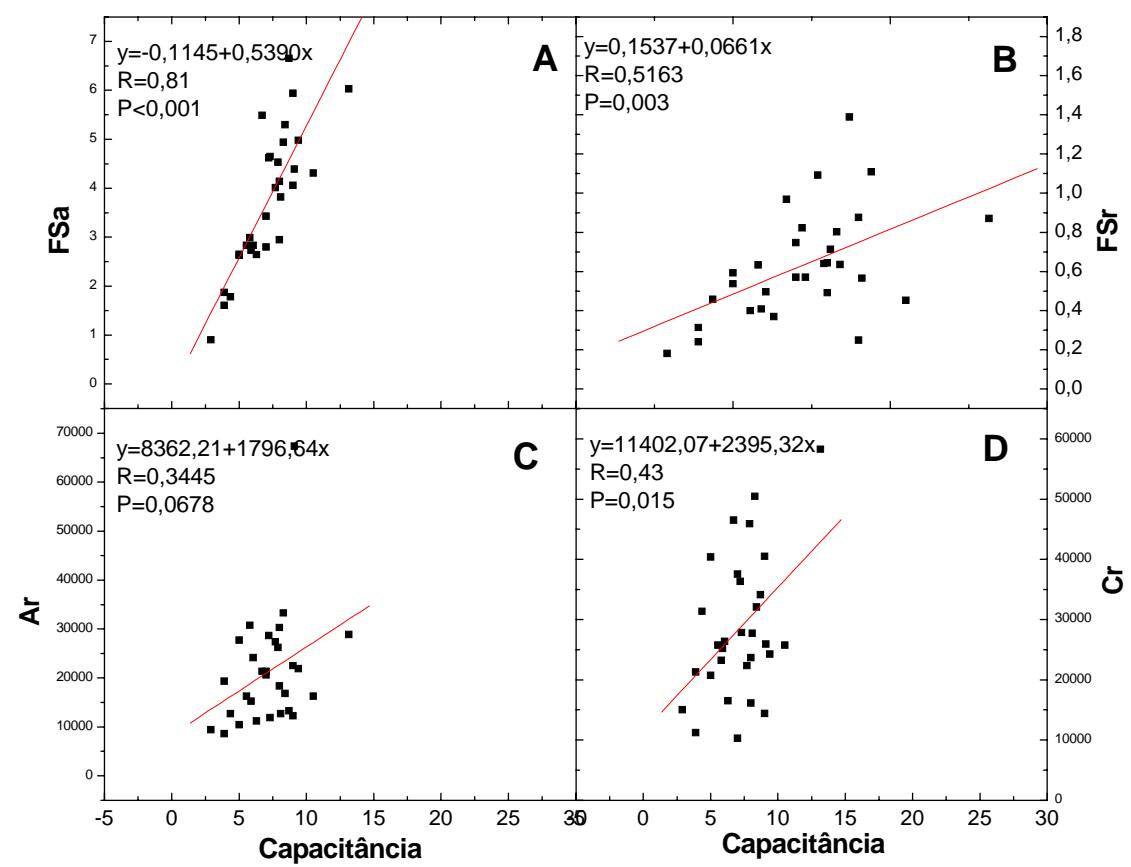

Figura 17 - Correlação entre valores de capacitância (200nF) e fitomassa seca aérea $\left(\right.$ FSa, g.planta $\left.{ }^{-1}\right)(A)$, fitomassa seca radicular (FSr, g.planta $\left.{ }^{-1}\right)(B)$, área do sistema radicular (Ar, $\mathrm{mm}^{2}$ ) (C) e comprimento radicular (C, mm) (D) de plantas de feijão, variedade cultivada Pérola, desenvolvidas com adição de P ao substrato

Foi também observada maior quantidade relativa de fitomassa no sistema radicular das plantas que se desenvolveram em substrato desprovido de P. A porcentagem de fitomassa fresca radicular em relação a fitomassa total nas plantas sem adubação foi de 32,49\%, enquanto nas plantas da testemunha de 13,22\%. 


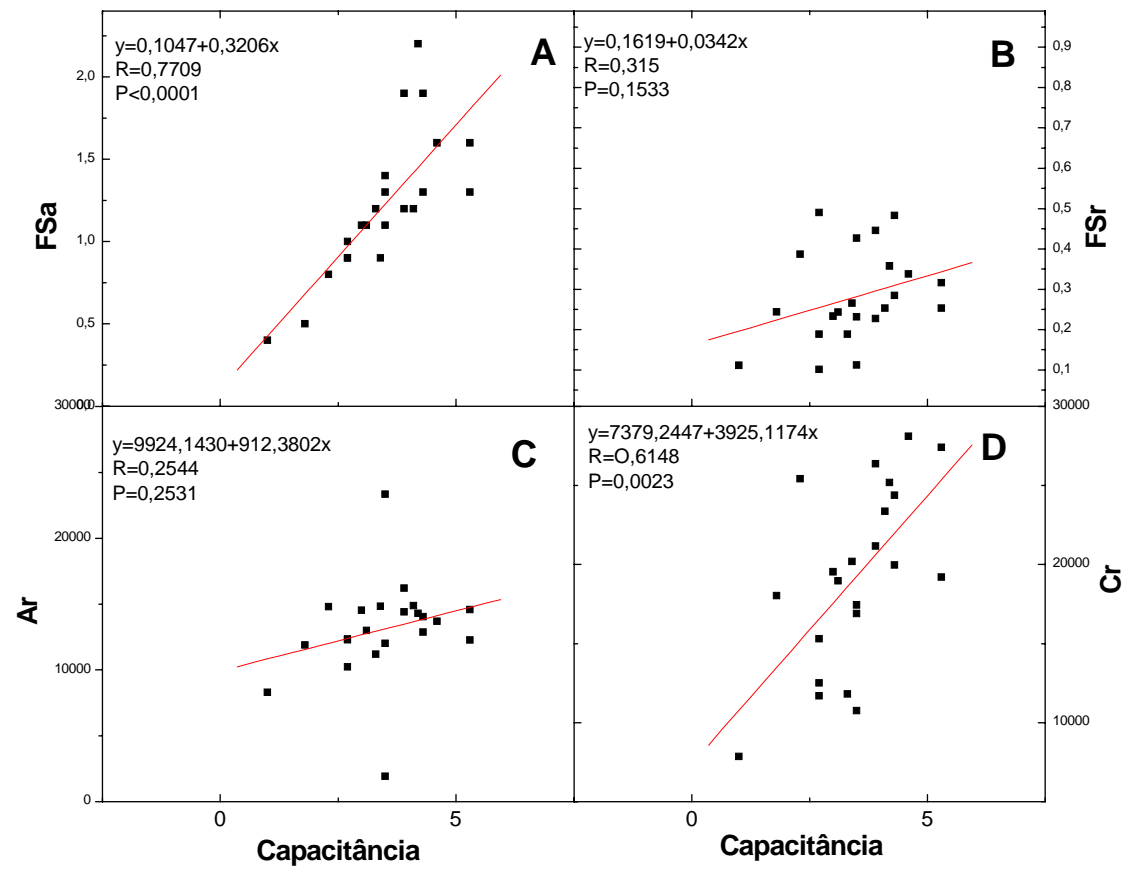

Figura 18 - Correlação entre valores de capacitância (200nF) e fitomassa seca de parte aérea (FSa, g.planta $\left.{ }^{-1}\right)(A)$, fitomassa seca radicular (FSr, g.planta $\left.{ }^{-1}\right)(B)$, área do sistema radicular (Ar, $\mathrm{mm}^{2}$ ) (C) e comprimento radicular (C, mm) (D) de plantas de feijão, variedade cultivada Pérola, desenvolvidas com adição de $\mathrm{P}$ ao substrato 

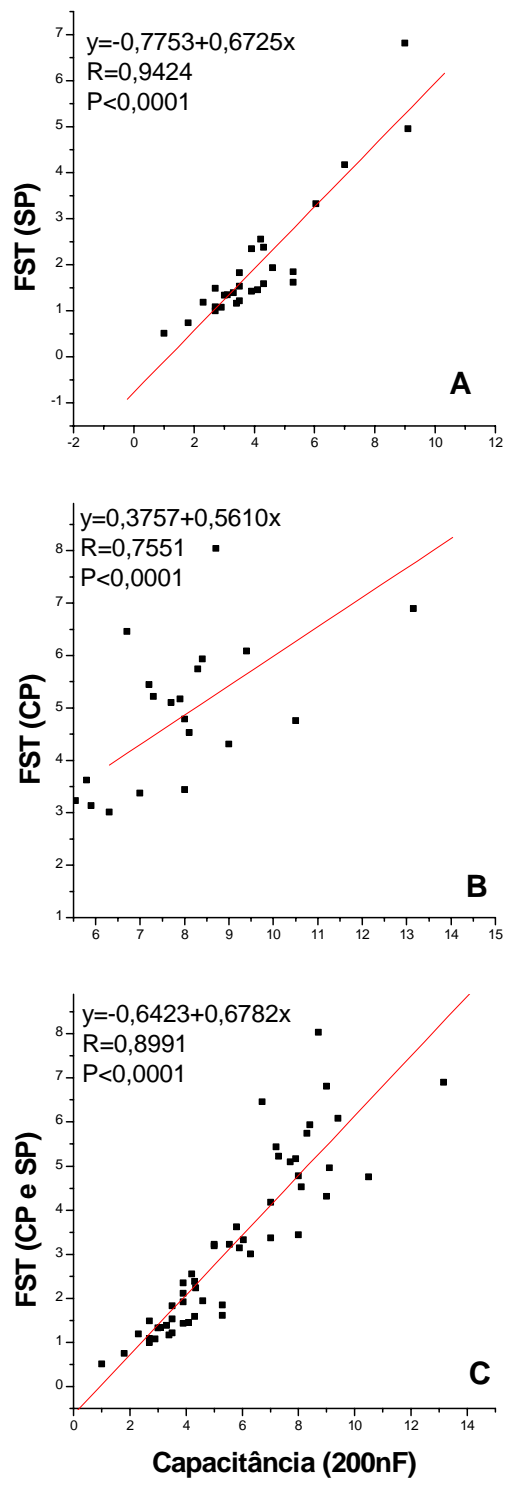

Figura 19 - Correlação entre valores de capacitância (200nF) e fitomassa seca total (FST, g.planta ${ }^{-1}$ ) no tratamento sem P (SP) (A), com P (CP) (B) e com (CP) e sem (SP) $\mathrm{P}$ adicionado ao substrato (C) de plantas de feijão (variedade cultivada Pérola) 


\subsection{Experimento III: seleção entre seis genótipos para o enraizamento adventício do feijoeiro comum em diferentes teores de fósforo no substrato (areia)}

Os resultados desse experimento preliminar são apresentados na Tabela 7, onde são ilustrados os números de raízes adventícias formadas nos diferentes genótipos e os valores de fitomassa seca dessa classe de raiz, onde foram discriminadas as raízes desenvolvidas até $6 \mathrm{~cm}$ de profundidade (raízes superficiais) e as raízes localizadas na parte inferior do vaso (profundas).

Neste estudo, embora os vasos tenham sido irrigados cinco vezes ao dia, supõese que as plantas sofreram deficiência hídrica, uma vez que não apresentaram o número de raízes adventícias esperado. Além disso, as sementes de alguns genótipos (17, 35 e 53) não geminaram. O substrato constituído de areia (100\%) não foi considerado adequado, por não permitir a manutenção de um teor de água suficiente para o desenvolvimento das plantas.

O experimento III não satisfez os objetivos, por isso foi repetido (experimento $\mathrm{V})$.

O genótipo G21 mostrou maior número de raízes adventícias, quando submetido à baixa dose de P. O genótipo GBR (Pérola), no entanto, apresentou maior enraizamento adventício sob dose alta de P. O genótipo G11 não apresentou raízes adventícias. Os demais genótipos, não puderam ser avaliados porque não germinaram em condições de baixo P. 
Tabela 7. Resposta de diferentes genótipos de feijoeiro comum à dose alta (Da) e à dose baixa $(\mathrm{Db})$ de $\mathrm{P}$, em que Nra se refere ao número de raízes adventícias, e FSrs, FSrp e FSra à fitomassa seca (g.planta ${ }^{-1}$ ) das raízes superficiais, das raízes profundas e das raízes adventícias, respectivamente

\begin{tabular}{|c|c|c|c|c|c|}
\hline Genótipo & Tratamento & Nra & FSrs (g.planta ${ }^{-1}$ ) & FSrp (g.planta ${ }^{-1}$ ) & FSra (g.planta ${ }^{-1}$ ) \\
\hline G11 & $\mathrm{Da}$ & 8 & 0,1951 & 0,2265 & 0,9 \\
\hline GBR & $\mathrm{Da}$ & 7 & 0,0317 & 0,1594 & 0,55 \\
\hline G17 & $\mathrm{Da}$ & 4 & 0,2589 & 0,1875 & 1,01 \\
\hline G53 & $\mathrm{Da}$ & 1 & 0,1855 & 0,2265 & 1,48 \\
\hline G21 & $\mathrm{Da}$ & 2 & 0,2123 & 0,1665 & 1,47 \\
\hline G35 & $\mathrm{Da}$ & 2 & 0,2639 & 0,1553 & 0,8 \\
\hline G11 & $\mathrm{Db}$ & 0 & 0,2965 & 0,3139 & 1,82 \\
\hline G35 & $\mathrm{Db}^{1}$ & - & - & - & - \\
\hline G21 & $\mathrm{Db}$ & 5 & 0,0809 & 0,3329 & 1,22 \\
\hline G17 & $\mathrm{Db}^{1}$ & - & - & - & - \\
\hline G53 & $\mathrm{Db}^{1}$ & - & - & - & - \\
\hline $\mathrm{GBR}^{2}$ & $\mathrm{Db}$ & 4 & 0,2589 & 0,1926 & 1,47 \\
\hline
\end{tabular}

\subsection{Experimento IV: seleção entre nove genótipos para o enraizamento adventício do feijoeiro comum em diferentes teores de fósforo no substrato (areia e vermiculita)}

A formação de raízes adventícias é considerada uma característica adaptativa a condições de baixo P (Miller, 1998; Lynch \& Brown, 1997). Embora este experimento preliminar tenha sido feito com o objetivo de avaliar a formação de raízes adventícias, outros parâmetros da planta também foram determinados.

A superficialidade do sistema radicular é observada através da fitomassa seca relativa, das raízes desenvolvidas na camada superficial (0 a $6 \mathrm{~cm}$ de profundidade) do solo (FSRrs, \%) (Figura 20). Como o P geralmente se concentra nas camadas 
superficiciais do solo (Ge, 2000; Liao, 2001; Rubioet al., 2003), maior FSRrs favorecem sua absorção.

A fitomassa seca relativa de raízes (FSRr, \%) reflete a proporção de fitomassa total da planta ocupada pelo sistema radicular. Plantas dos genótipos G17, G21, G57 e G61 aparesentaram maior porporção de raiz, quando desenvolvidas com dose alta de fósforo (Da). As plantas dos genótipos G6, G11, G23 e GBR (Pérola), apresentaram maior FSRr, sob Db, o que indica aumento da exploração do solo em condições de baixa disponibilidade de $\mathrm{P}$.

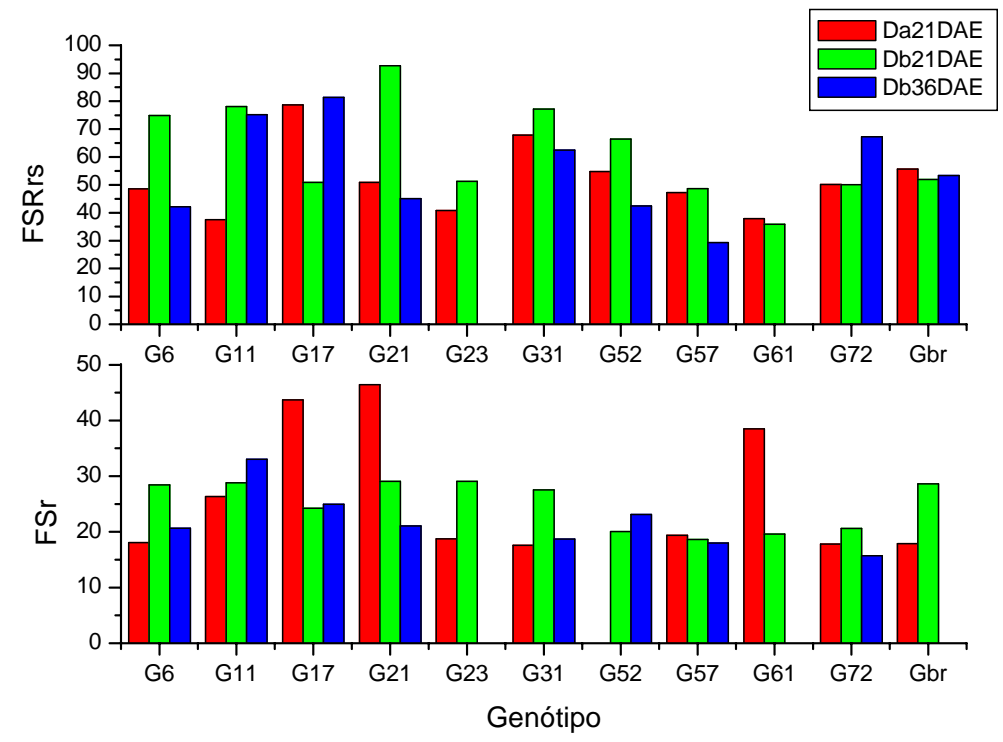

Figura 20 - Fitomassa seca relativa de raízes na camada superficial (0-6 cm) (FSRrs, \%) e fitomassa seca do sistema radicular (FSr, g.planta ${ }^{-1}$ ), de nove genótipos de feijoeiro comum, aos 21 e 36 dias após emergência, sob alta (Da) e baixa (Db) dose de $\mathrm{P}$

O comprimento e o número de raízes adventícias são ilustrados na Figura 21. O comprimento das raízes adventícias (Cra, cm) foi maior em Db nos genótipos G11, G21, G23 e G57, quando comparados com Da. Maior valores de Cra, sugerem maior exploração das camadas superiores do substrato. Os genótipos G17, G31 e Pérola (GBR), apresentaram valores superiores de Cra, quando sob Da. 
Os genótipos G6 e G52 apresentaram, em todas as situações, elevado número de raízes adventícias (Nra) (Figura 21). Os genótipos G11 e G32 apresentaram comportamento oposto. Na variedade cultivada Pérola (GBR), não houve efeito da dose de fósforo sobre o número de raízes adventícias. O genótipo G21 apresentou formação de um número mais elevado de raízes adventícias, quando foram submetidos ao nível mais alto de fósforo. Os genótipos G57 e G11 apresentaram maior número de raízes quando o teor de fósforo foi reduzido.

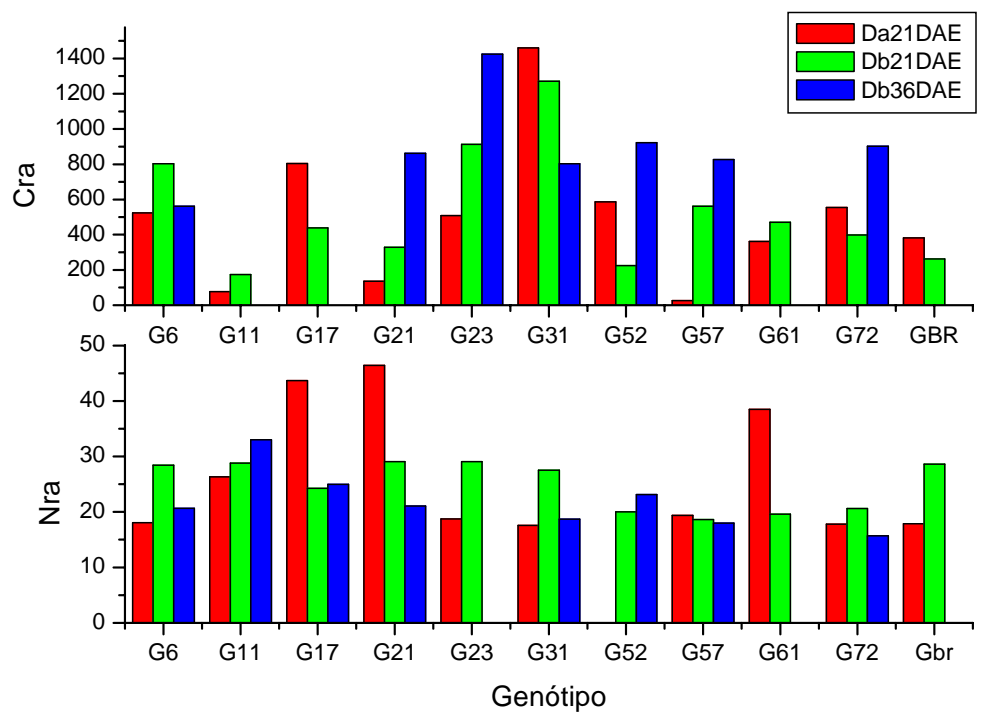

Figura 21 - Comprimento (Cra, mm) e número de raízes adventícias (Nra) de nove genótipos (G6, G11, G17, G21, G23, G31, G52, G57, G61, G72 e GBR) de feijoeiro, aos 21 e 36 dias após emergência, sob alta (Da) e baixa (Db) dose de $\mathrm{P}$

Deve-se salientar que, os resultados deste experimento foram considerados apenas para a orientação na escolha dos genótipos a serem empregados para o experimento principal. Como a disponibilidade de sementes era baixa, não foram realizadas repetições para avaliações estatísticas. 


\subsection{Experimento V: efeito do teor e da distribuição de fósforo no substrato no desenvolvimento de cinco genótipos do feijoeiro comum}

O fósforo geralmente se localiza nos horizontes superficiais do solo (Lynch \& Brown, 2001; Robinson, 1994; Robinson, 1996a; Robinson, 1996b). Para simular essas condições, estabeleceu-se um tratamento em que o nível de fósforo foi estratificado, sendo este, mais elevado na camada superior do vaso (Rubio et al., 2003). A princípio foram incluídos cinco genótipos (G6, G11, G21, G31 e G57). Mas, em função da manifestação de sintomas de vírus, o genótipo G31 foi excluído.

Aos 21 DAE, é possível observar diferenças visuais entre as plantas sob alta (Da) e baixa dose de $\mathrm{P}(\mathrm{Db})$. As diferenças se tornam mais evidentes aos $28 \mathrm{DAE}$. As plantas sob Db são menores e com número de folhas e área foliar inferiores. As hastes são mais finas, e os inter-nós mais curtos. Apresentam sintomas visuais semelhantes aos descritos na literatura para plantas deficientes em P (Salisbury \& Ross, 1992; Hall \& Schawartz em Bennette, 1994; Marschner, 2002; Taiz \& Zeiger, 2003).

A fitomassa seca total (FST, g.planta ${ }^{-1}$ ) aumentou, ao longo do tempo, para todos os genótipos, em todos os tratamentos. Essa foi significantemente maior nas plantas submetidas a Da em todos os genótipos, o que concorda com diversos estudos anteriores (Cakmak, 1994; Snaap et al., 1995; Nielsen et al., 1998; Liao et al., 2001, Nielsen et al., 2001). O mesmo resultado foi observado para FSa (g.planta ${ }^{-1}$ ) e (FSr, g.planta ${ }^{-1}$ ), para todos os genótipos (Figura 23). Esse resultado é coerente aos encontrados na literatura (Snaap et al., 1995; Marschener, 2002; Taiz \& Zeiger, 2003), e é explicado pela redução na expansão de folhas novas apresentadas por plantas sob deficiência de P (Terry \& Rao,1991). Miller et al. (2003), no entanto, não observaram efeito significante sobre a FSr sob baixa disponibilidade de P em plantas de feijão.

A fitomassa seca radicular (raízes adventícias) relativa da planta (FSRra, \%), avaliada aos 14, 21 e 28 DAE (Figura 22), expressa a quantidade de fitomassa total empregada no sistema radicular, ao longo do tempo. Essa foi maior em Da, em todos os genótipos, nos períodos avaliados. 


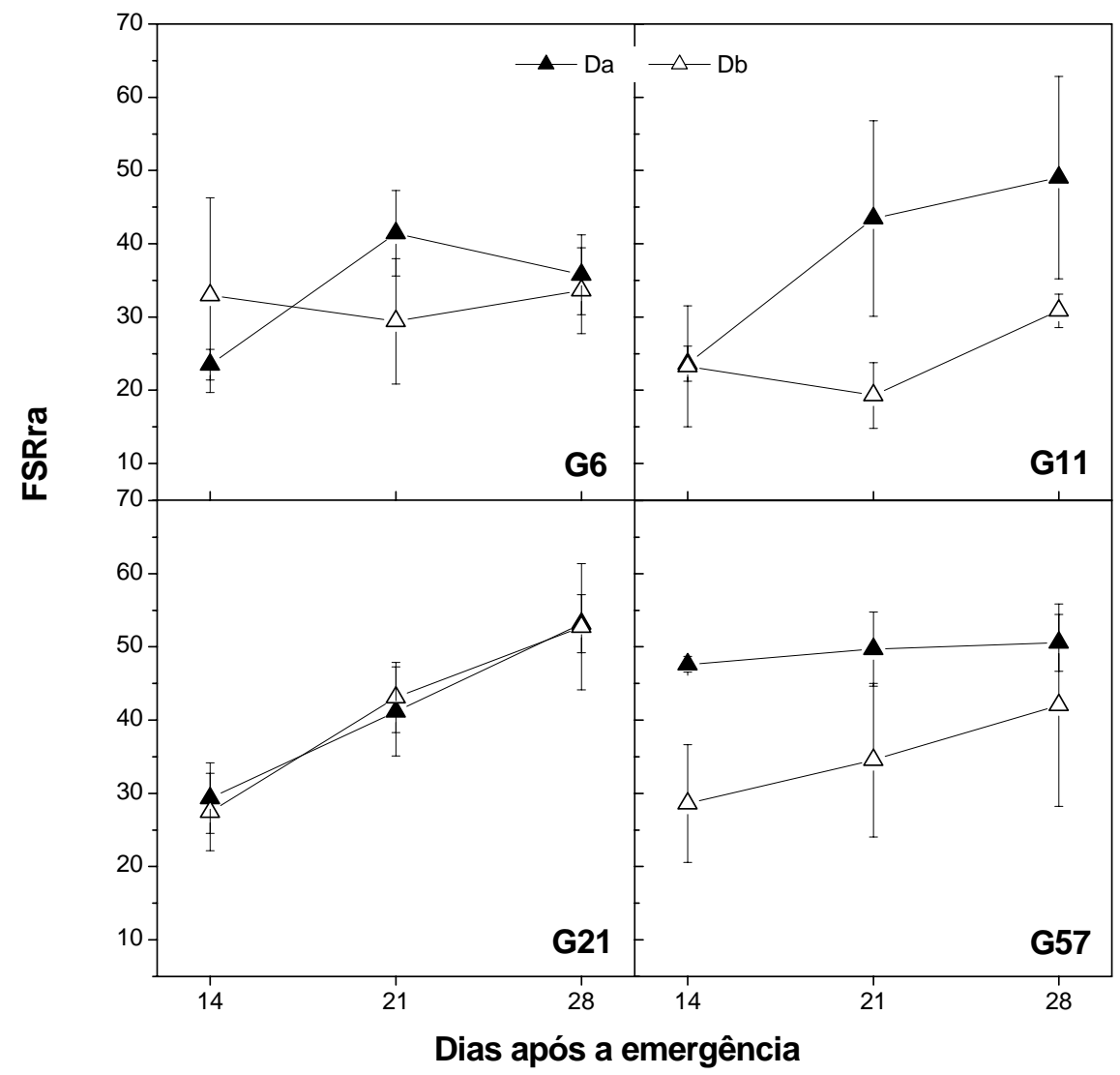

Figura 22 - Fitomassa seca de raízes adventícias (FSRra, \%) (genótipos G6 - A, G11 - B, G21 - C - e G57 - D) sob dose alta (Da) e baixa (Db) de P no substrato, aos 14, 21 e 28 dias após a emergência

O desenvolvimento do sistema radicular é relacionado às condições do solo (Taiz \& Zeiger, 2003) e da parte aérea (Salisbury \& Ross, 1992). O acúmulo de fitomassa seca do sistema radicular, ao longo do tempo (FSRr, g.planta ${ }^{-1}$ ) (Figura 24), não mostrou a mesma tendência para os diferentes genótipos. A Db foi significativamente maior em todas as idades, para todos os genótipos. G6, sob Db teve a FSRr significativamente maior aos 14 DAE. O efeito do tempo foi significativo em G11, sob Da e Db, quando 
compara-se a FSRr aos 14 e 28 DAE. O fato de plantas, sob condições de baixa disponibilidade de $\mathrm{P}$, exibirem maior alocação de carbono para o sistema radicular, já é conhecido (Marschener, 2002; Taiz \& Zeiger, 2003).
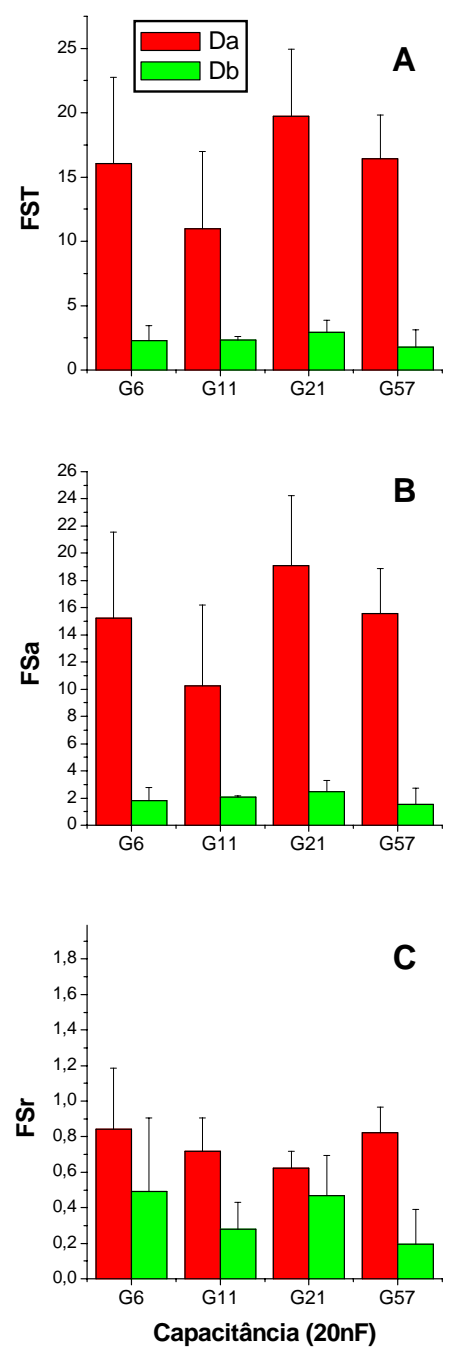

Figura 23 - Fitomassa seca total (FST, g.planta ${ }^{-1}$ ) (A), de parte aérea (FSa, g.planta ${ }^{-1}$ ) (B) e radicular (FSr, g.planta ${ }^{-1}$ ) de plantas de feijão (genótipos G6, G11, G21 e G57) aos 28 dias após a emergência 


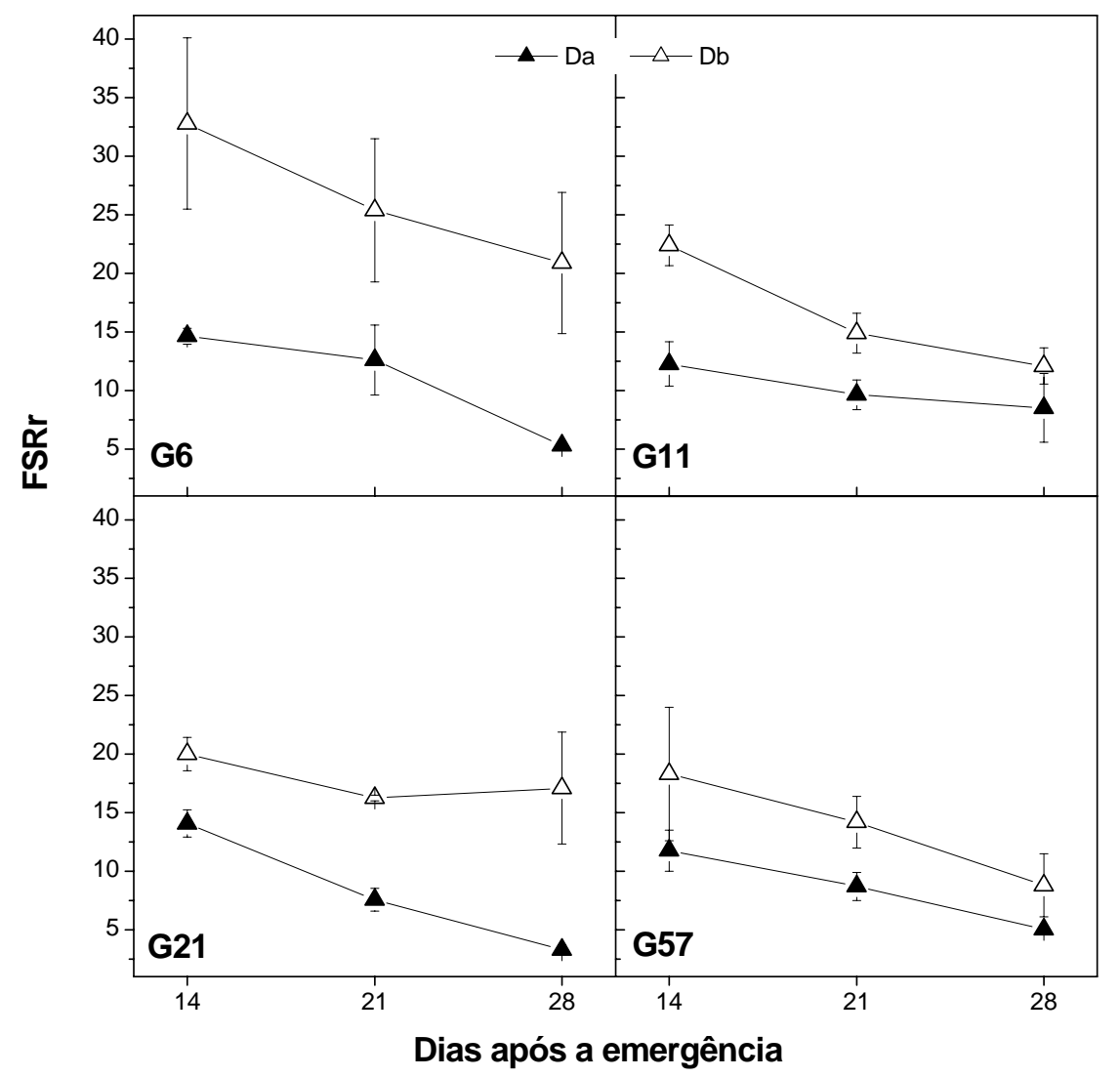

Figura 24 - Fitomassa seca relativa do sistema radicular (FSRr, \%) dos genótipos G6 (A), G11 (B), G21 (C) e G57 (D) de feijoeiro submetidas a dose alta (Da) e baixa (Db) de P no substrato, aos 14, 21 e 28 dias após a emergência

A disponibilidade de $\mathrm{P}$ no solo interfere em todos os aspectos da partição de carboidrato na planta (Nielsen et al., 2001). O mecanismo de distribuição de fitomassa seca é determinado geneticamente (Jesko, 1994) pela demanda de nutrientes pela parte aérea, e de carboidrato pelo sistema radicular (Salisbury \& Ross, 1992). A semelhança genética entre os híbridos recombinantes aqui estudados, porporcionou resposta parecida 
na relação entre raiz e parte aérea (Rrpa) (Figura 25). A Rrpa, no entanto, foi significantemente maior em $\mathrm{Db}$, para todos os genótipos.

$\mathrm{O}$ aumento Rrpa em condições de baixa disponibilidade de $\mathrm{P}$ tem sido amplamente divulgado (Cakmak et al., 1994; Halsted \& Lynch, 1996; Nielsen et al., 2001; López-Bucio et al., 2002; Marschener, 2002), porque nessas condições ocorre maior alocação de carbono para as raízes (Nielsen et al., 1998).

Cakmak et al. (1994) verificaram que plantas de feijão apresentaram uma relação parte aérea e raiz de 4,9 no controle e 1,8 nas plantas sem P. Marschener (2002) afirma que a relação entre parte aérea e sistema radicular cai de 5,0 para 1,9 quando as plantas de feijão são submetidas a deficiência de P.

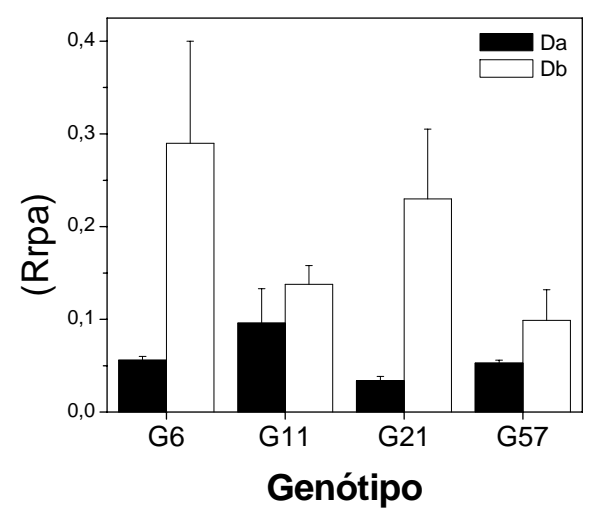

Figura 25 - Relação entre raiz e parte aérea (Rrpa) dos genótipos G6, G11, G21 e G57 aos 28 dias após a emergência

O comprimento total do sistema radicular $(\mathrm{Cr}, \mathrm{mm})$ não apresentou diferença significatriva entre os genótipos. O $\mathrm{Cr}$ foi significativamente maior para Da. Comportamentos semelhantes foram observados (Miller et al, 2003) para os genótipos G2333 e G19839, que deram origem aos híbridos recombinantes aqui estudados.

O comprimento específico (Cre, $\mathrm{mm} \cdot \mathrm{g}^{-1}$ ) (Figura 26) do $\mathrm{G} 6$ foi significativamente superior aos demais genótipos. Miller et al. (2003) expressam o Cre 
como “custo linear da raiz”. Raízes que exploram o solo com menor investimento de fitomassa são as que exploram maior volume de solo por unidade de massa de raiz. Genótipos que apresentam maior comprimento específico, como G6, são tidos como mais eficientes nesse aspecto (Nielsen et al., 1998).

Todas as partes do sistema radicular do feijoeiro estão envolvidas na exploração de horizontes superficiais do perfil e sujeitas a regulação pela disponibilidade de fósforo no substrato (Lynch \& Brown, 2001). A superficialidade do sistema radicular foi aferida através da distinção da raiz desenvolvida na camada de 0 a 6 cm (FSRr, \%). Nesse parâmetro não foi verificada interação entre os níveis de $\mathrm{P}$ e o genótipo, mas diferença significativa dentro dos genótipos nas duas doses de P. A diferença significativa é expressa pelas letras que seguem os genótipos, que foram dispostos em ordem decrescente G57 a, G6 ab, G11 ab e G21 b.

Condições de baixa disponibilidade de $\mathrm{P}$ podem proporcionar, em plantas de feijão, alteração na ramificação e no comprimento das raízes, conferindo uma arquitetura radicular mais favorável para a exploração do solo (Borch et al., 1999; Borch et al., 1999; Carswell et al., 1996). Essas condições têm sido associadas ao desenvolvimento de sistemas radiculares capazes de explorar maior volume de solo (Ge et al., 2000; Nielsen et al., 1998).

Miller et al. (2003) observaram efeito da disponibilidade de P relacionada ao genótipo sobre as classes de raiz (raiz pivotante, basal e adventícia). Nesse estudo foi dada especial atenção às raízes adventícias. Essas foram separadas das demais, para que fossem avaliadas. Alguns estudos (Miller, 1998; Miller et al., 1998; Miller et al., 2003) mostram que, para o feijoeiro comum, as raízes adventícias conferem aumento no crescimento da raiz e na absorção de $P$, resultando em maior eficiência, em condições de baixa disponibilidade de P (Miller, 1998; Miller et al., 1998). 


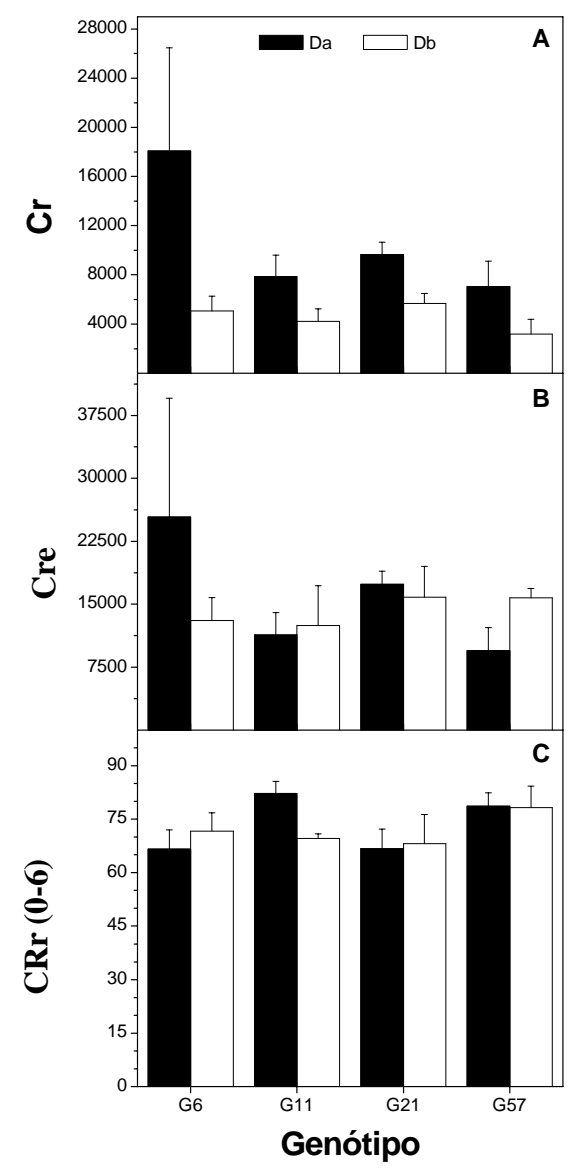

Figura 26 - Comprimento radicular (Cr, cm) (A), comprimento radicular específico (Cre, $\mathrm{cm} \cdot \mathrm{g}^{-1}$ ) (B) e fitomassa seca relativa de raízes (CRr, \%) (C) de quatro genótipos de feijoeiro, submetidas a dose alta (Da) e baixa (Db) de P no substrato, aos 28 dias após a emergência

A proporção de fitomassa seca do sistema radicular empregada nas raízes adventícias (FSRra, \%) foi avaliada aos 14, 21 e 28 DAE (Figura 27). As avaliações foram realizadas ao longo do desenvolvimento vegetativo porque o balanço, entre parte aérea e sistema radicular, é dinâmico e sujeito a modificações (Jesko, 1994; Nielsen et al. 1998). Em G6, não foi observada diferença significativa do efeito da dose de $P$, ou 
idade da planta, sobre a FSRra. A dose de P, em G11, proporcionou FSRra significativamente maior em Da. Em G21, o tempo apresentou efeito significativo para G57. Não houve variação significativa dos efeitos do P e da idade da planta sobre a FTRra.

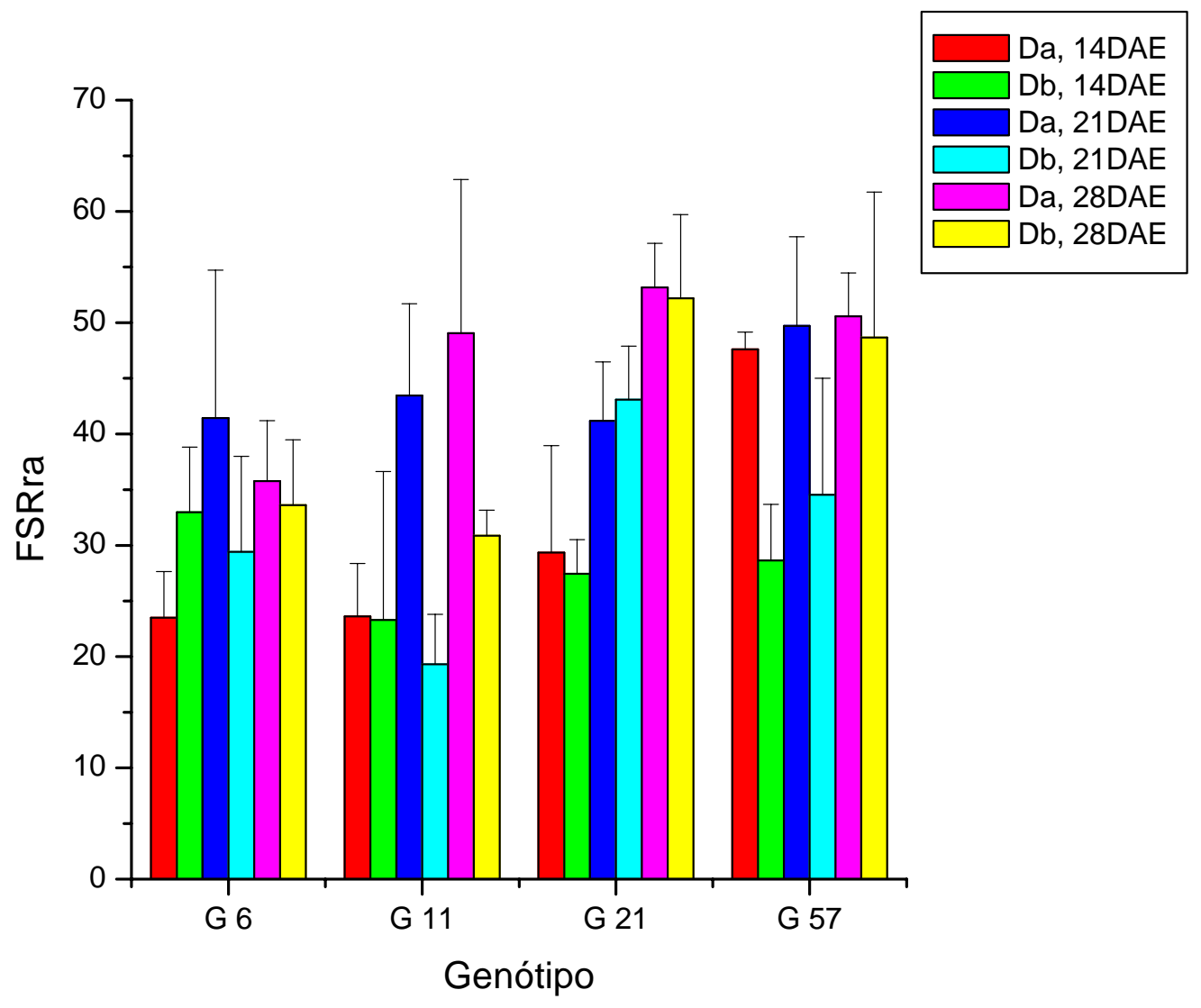

Figura 27 - Fitomassa seca de raízes adventícias (FSRra, \%) em relação ao valor total de fitomassa de plantas de diferentes genótipos (feijoeiro) submetidas a dose alta (Da) e baixa (Db) de P, aos 14, 21 e 28 dias após a emergência

Os genótipos, empregados neste estudo são híbridos recombinantes originários do nono cruzamento entre G2333 e G19839. Esses últimos foram estudados por Miller et al. (2003), e mostraram respostas contrastantes sobre a FSRra, em condições de baixo P (Miller et al., 2003). 
Na Figura 28 pode ser verificado que G6 e G21 apresentaram elevado número de raízes adventícias. Esse número foi maior nas plantas submetidas a Db, com exceção dos valores observados em G6 aos 21 DAE, quando o número de raízes adventícias em Da foi maior. O genótipo G11 apresentou menor número de raízes adventícias, quando comparados aos demais genótipos.

Miller et al. (2003) observaram grande variação do número de raízes adventícias, em condições de baixo P, no germoplasma do feijoeiro comum.

Quando as raízes adventícias são avaliadas em termos de comprimento (Cra, mm) (Figura 28), observa-se que o Cra foi significativamente maior em Da em todos os genótipos. A idade da planta não proporcinou diferença significativa nesse parâmetro. Os valores de Cra, para os genótipos aqui estudados, foram inferiores aos observados para seus progenitores (G2333 e G19839) em esudo realizado por Miller et al. (2003).

A avaliação do número de raízes adventícias formadas (Nra) (Figura 28) não mostrou efeito significante da dose de P. Nesse parâmetro, no entanto, observa-se que a diferença entre os genótipos foi significativa. Essa diferença é expressa pelas letras que seguem a identificação do genótipo, que foram colococados em ordem decrescente de Nra. G21 AB; G6 BC; G57 C e G11 C. Os resultados obtidos comprovam observações prévias de variação genotípica no feijoeiro comum do Nra em condições de baixo P (Miller et al., 2003; Miller, 1998; Miller et al., 1998).

A respiração do sistema radicular repesenta um dos principais componentes do custo de carbono (Nielsen et al., 1998). Uma vez que plantas de feijão, sob baixa disponibilidade de $\mathrm{P}$ apresentam maior FSRr, é esperado que a taxa de respiração (valores relativos) em Db seja maior (Nielsen et al., 1998; Nielsen et al., 2001). Por isso, a taxa de respiração (TR, $\mu \mathrm{mol} \cdot \mathrm{min}^{-1} \cdot \mathrm{g}^{-1}$ de $\mathrm{CO}_{2}$ ) foi relacionada com a fitomassa seca (Figuras 29 e 30) e comprimento (Figura 28) do sistema radicular.

A taxa de respiração específica (TR, $\mu$ mol.min ${ }^{-1} \cdot \mathrm{g}^{-1}$ de $\mathrm{CO}_{2}$ ) (Figura 29) não apresentou efeito significativo da idade, ou da dose de P, em nenhum dos genótipos estudados. No entanto, quando é expressa em comprimento de raiz (TR, $\mu m o l . \mathrm{min}^{-1} \cdot \mathrm{m}^{-1}$ de $\mathrm{CO}_{2}$ ) (Figura 30), apenas G6 não apresentou diferença significativa. Em G11, a 
respiração foi significativamete menor $\mathrm{Db}$. TR foi significativamante maior aos $28 \mathrm{DAE}$ em G21, e aos 14 e 28 dias em G57.
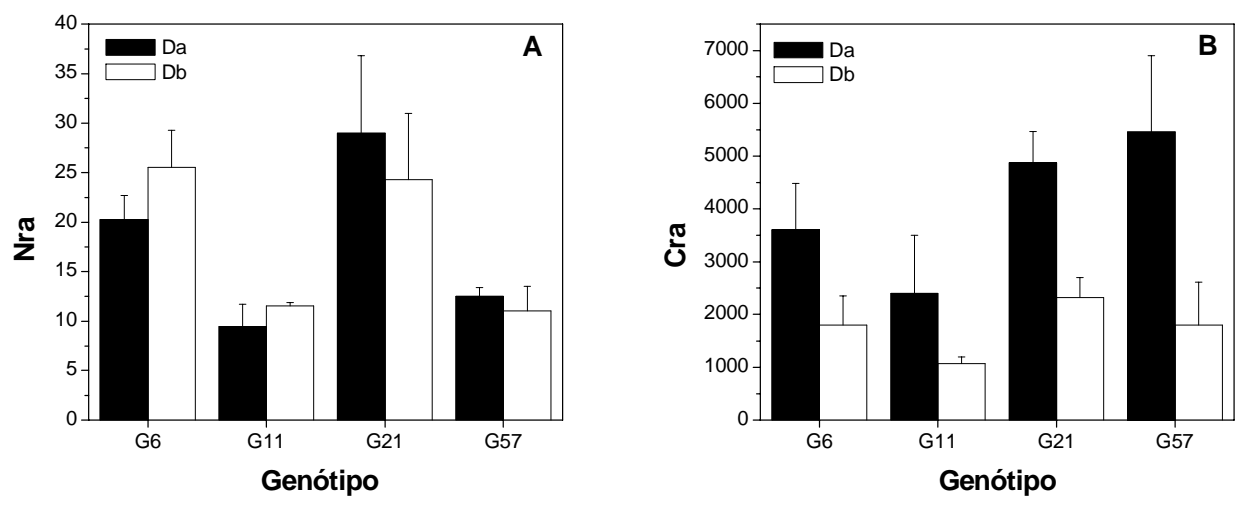

Figura 28 - Número (Nra) e comprimento (Cra, mm) de raízes adventícias de quatro genótipos (G6, G11, G21 e G57) de feijoeiro comum, submetidos à dose alta (Da) e baixa (Db) de P no substrato, aos 28 dias após a emergência

Através da respiração é obtida energia para o crescimento, manutenção dos tecidos radiculares, e transporte de íons e solutos contra o gradiente de concentração (Gasparikóvá, 1994). A taxa de respiração do sistema radicular, ao longo do tempo, é extremamente relacionada à taxa fotossintética e a translocação de açúcares para as raízes (Salisbury \& Ross, 1992), que por sua vez, estão relacionados à disponibilidade de P no solo (Marschener, 2002).

O controle da fração de carboidrato perdida na respiração, sob condições de estresse, determina a eficiência metabólica da planta (Lynch \& Beebe, 1995; Nielsen, et al., 2001). A taxa de respiração é regulada tanto por condições do meio ambiente, como por requerimento de energia (Gasparikóvá, 1994). Quando em condições de baixa disponibilidade de P, a TR ( $\mu$ mol.min ${ }^{-1} \cdot \mathrm{m}^{-1}$ de $\mathrm{CO}_{2}$ ) menor, apresentada de G11, faz esse genótipo ser o mais eficiente no que diz respeito ao gasto energético para exploração do solo. O menor valor de TR apresentado por G11, não está associado com a menor 
espessura radicular, uma vez que os valores de Cre de G11 não foram elevados quando comparados aos demais genótipos.

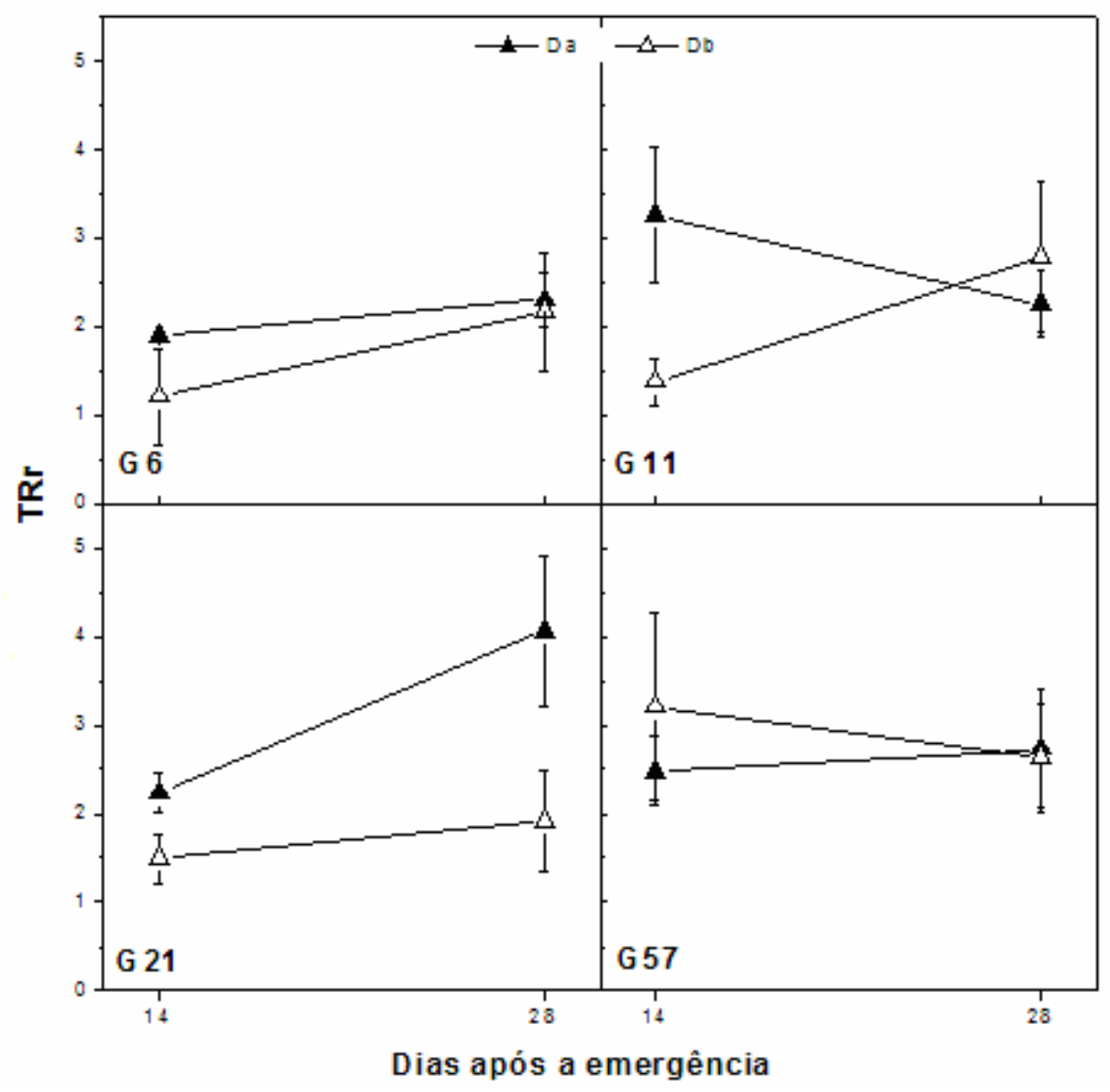

Figura 29 - Taxa de respiração radicular (TRr, $\mu$ mol.min ${ }^{-1} \cdot \mathrm{g}^{-1}$ de $\left.\mathrm{CO}_{2}\right)$ de diferentes genótipos de feijoeiro: G6 (A), G11 (B), G21 (C) e G57 (D), submetidos à dose alta (Da) e baixa (Db) de P no substrato, aos 14 e 28 dias após a emergência

A capacitância é baseada na polarização das membranas do sistema radicular (Choupek et al., 1999). No experimento I, as determinações de capacitância se mostraram melhores quando feitas a $20 \mathrm{nF}$. No presente estudo, no entanto, as determinações se mostraram mais adequadas quando realizadas a 200nF. Van Beem determinou os valores de capacitância, em milho, nas duas escalas. Na prática, verificouse que a escala varia conforme o tamanho da planta. E sua determinação é facilmente 
verificada no momento das medições, em função da velocidade de estabilização do aparelho em cada escala.

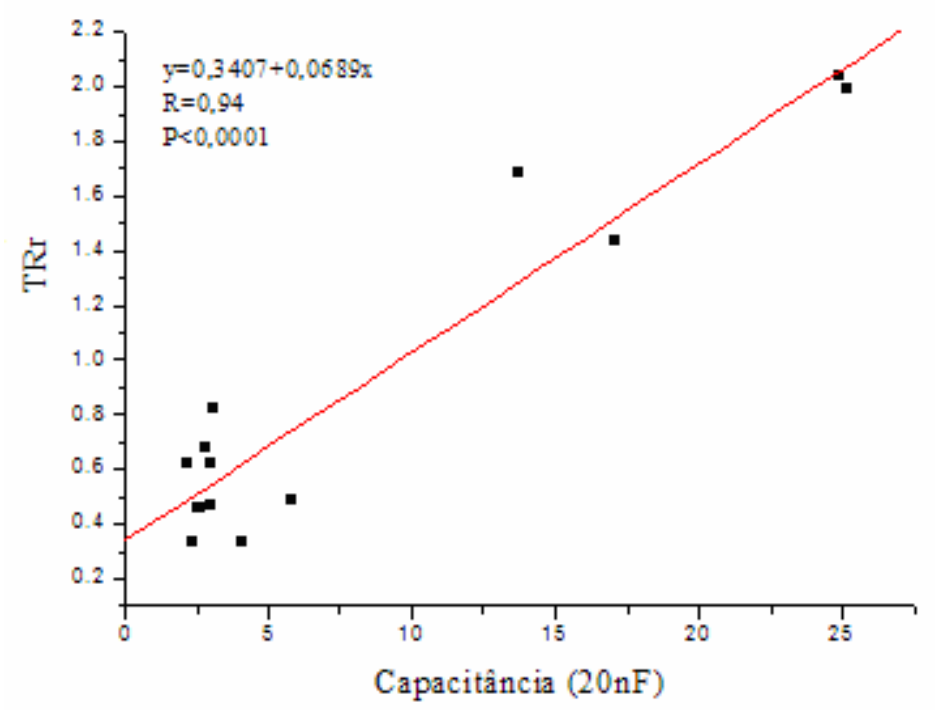

Figura 30 - Taxa de respiração radicular (TRr, $\mu$ mol.min ${ }^{-1} \cdot \mathrm{m}^{-1}$ de $\mathrm{CO}_{2}$ ) de diferentes genótipos de feijoeiro: G6 (A), G11 (B), G21 (C) e G57 (D), submetidas à dose alta (Da) e baixa (Db) dose de P, determinadas aos 14 e 28 dias após a emergência

A Figura 31 ilustra os valores de capacitância dos seis genótipos aos 28 DAE. Os valores de capacitância seguem o padrão do acúmulo de fitomassa seca. Esse padrão é extremamente semelhante ao observado ao de fitomassa seca total, sugerindo que a capacitância pode ser empregada para comparar valores de fitomassa total, em feijoeiro, independentemente do genótipo empregado. Vale salientar que os genótipos empregados apresentam a mesma descendência, o que supostamente favorece a semelhança de propriedade dielétrica radicular (Dalton, 1995).

O efeito que a suberização sobre as propriedades eletrofísicas da raiz, que aumenta com a idade da raiz, é detectada pelo valor de capacitância (Dalton, 1995). Esse método, portanto, não reflete a relação linear entre fitomassa seca e área da raiz. A possibilidade de distinguir a parte funcional do sistema radicular, em uma escala macroscópica, pode vir a ser muito útil em estudos de eficiência do sistema radicular em diferentes condições de estresse (Dalton, 1995). 


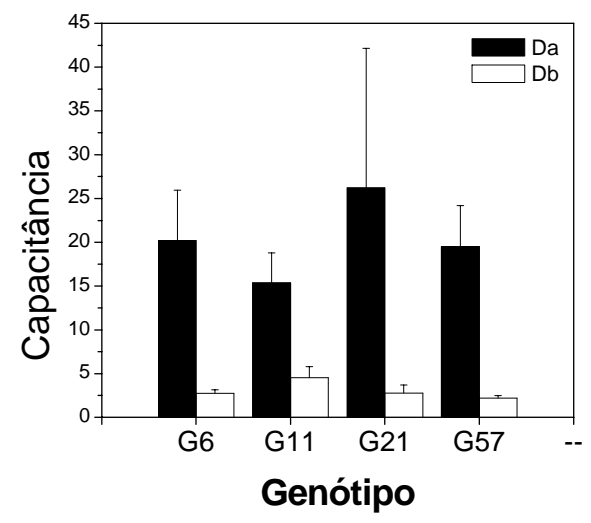

Figura 31 - Valores médios de capacitância (20nF) de plantas de feijão (G6, G11, G21 e G57), aos 28 dias após a emergência

A Figura 32 ilustra a variação temporal (aos 14, 21 e 28 dias) dos coeficientes de correlação entre valores de capacitância $(20 \mathrm{nF})$ e fitomassa seca radicular, de parte aérea, total e comprimento radicular de quatro genótipos de feijoeiro.

As Figuras 33 a 41 ilustram a correlação entre capacitância e fitomassa seca do sistema radicular (FSr, g.planta ${ }^{-1}$ ), total (FST, g.planta ${ }^{-1}$ ) e da parte aérea (FSa, g.planta ${ }^{-1}$ ) e comprimento do sistema radicular (Cr, mm) de plantas de feijão (genótipos G6, G11, G21 e G57) aos 14, 21 e 28 dias após a emergência. Os valores de correlação observados, para os diferentes híbridos recombinantes, mostraram-se distintos, mas com a mesma tendência. Para todos os genótipos, os valores de correlação foram mais elevados entre capacitância e FST.

Segundo Dalton (1995), não há dados que expliquem o efeito da variedade sobre as propriedades dielétricas do tecido radicular. Se a diferença entre variedades proporcionar diferença nas propriedades dielétrica da raiz, essa informação deve ser explorada e correlacionada com características físicas do transporte no sistema radicular. 


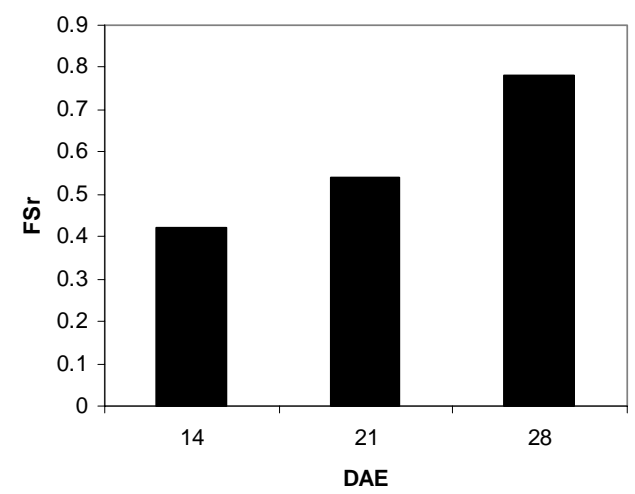

(A)

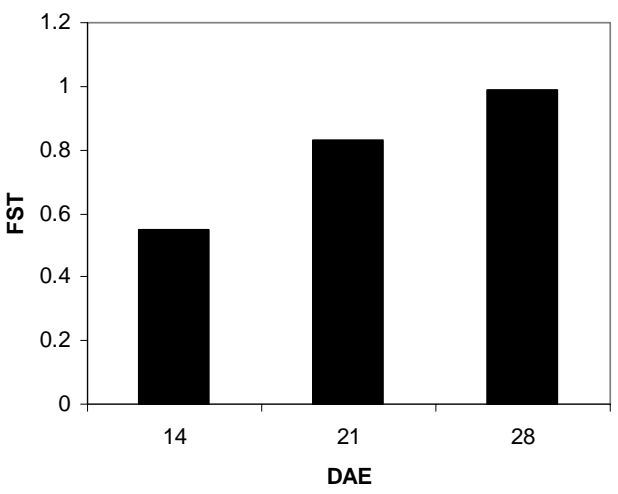

(C)

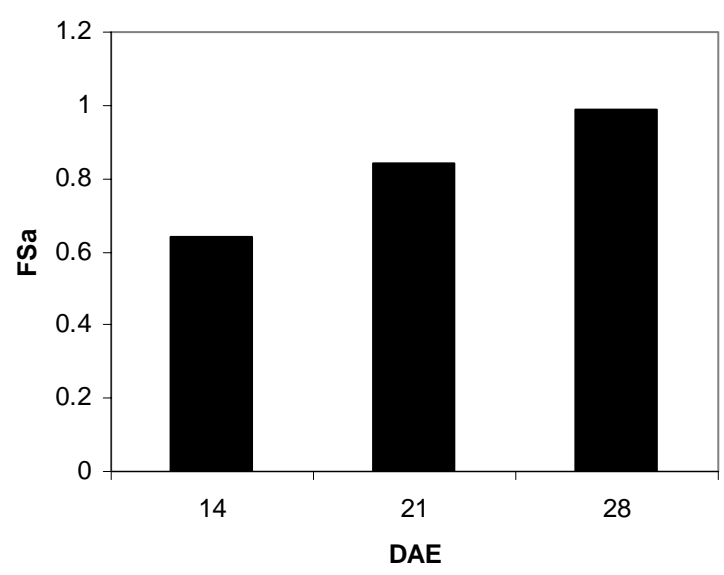

(B)

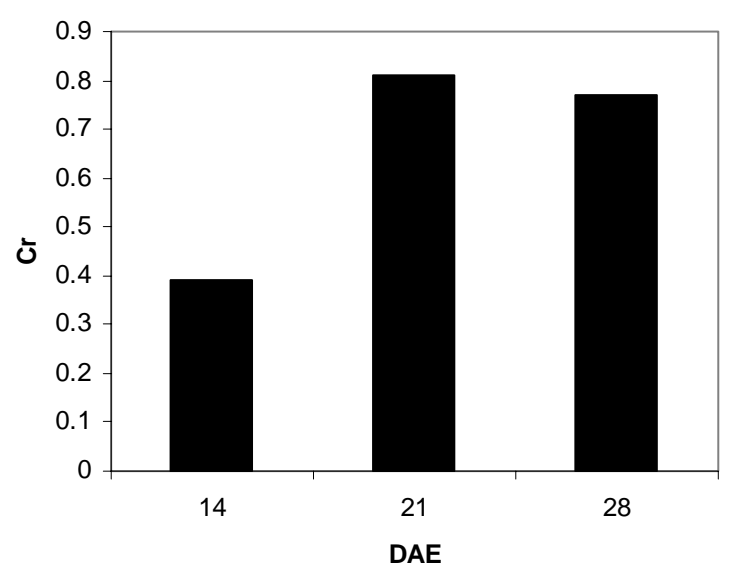

(D)

Figura 32 - Coeficientes de correlação entre médias de quatro repetições de valores de capacitância (20 nF) e (A) fitomassa seca radicular (FSr, g.planta $\left.{ }^{-1}\right)$, (B) fitomassa seca de parte aérea (FSa, g.planta ${ }^{-1}$ ), (C) fitomassa seca total (FST, g.planta ${ }^{-1}$ ), e (D) comprimento radicular (Cr, cm), aos 14, 21 e 28 dias de quatro genótipos de feijoeiro 

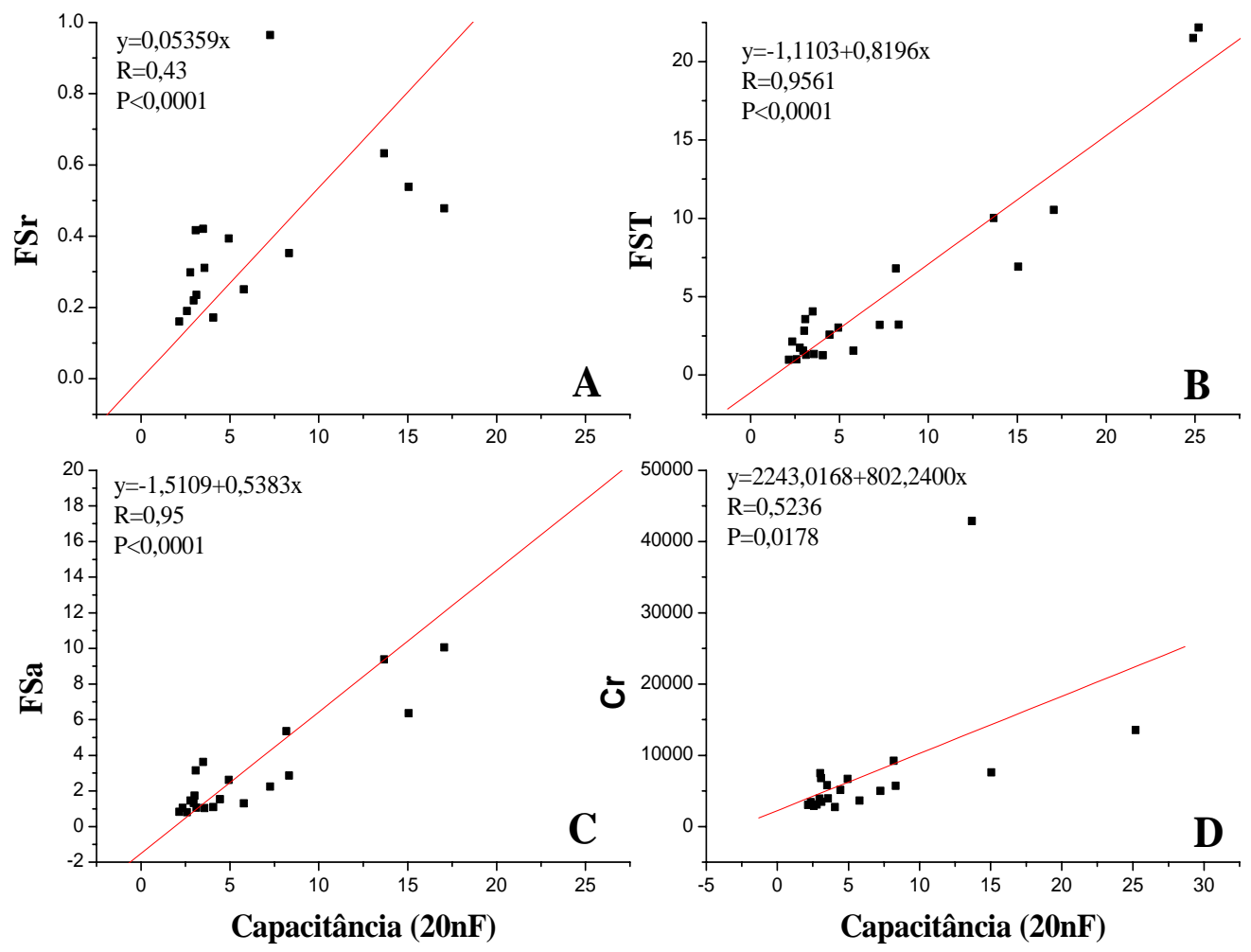

Figura 33 - Correlação entre capacitância e fitomassa seca do sistema radicular (FSr, g.planta $^{-1}$ ) (A), total (FST, g.planta $\left.{ }^{-1}\right)(B)$, da parte aérea (FSa, g.planta $\left.{ }^{-1}\right)(C)$ e comprimento do sistema radicular (Cr, mm) (D) de plantas de feijão do genótipo G6, aos 14, 21 e 28 dias após a emergência 

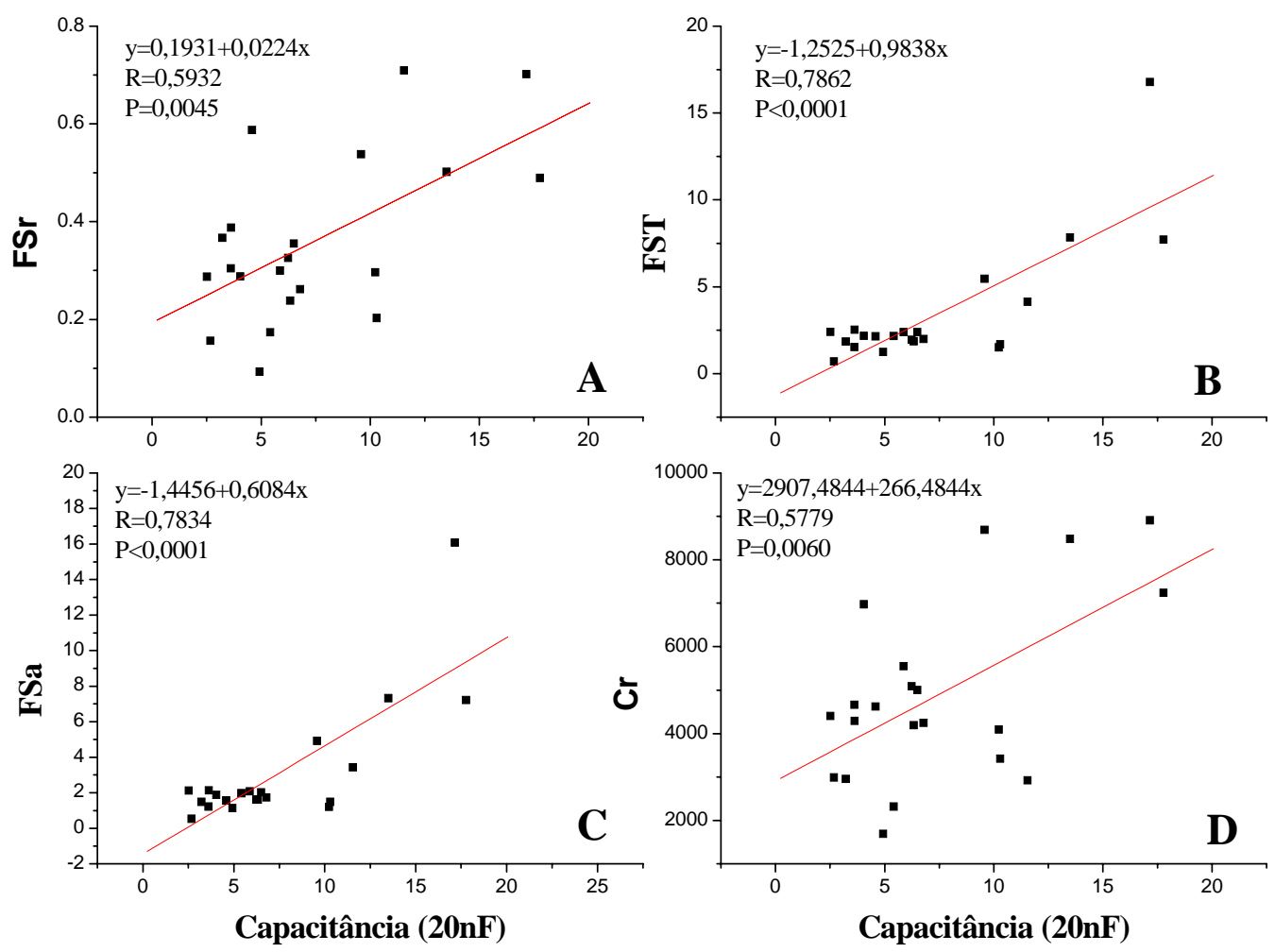

Figura 34 - Correlação entre capacitância e fitomassa seca do sistema radicular (FSr, g.planta ${ }^{-1}$ ) (A), total (FST, g.planta ${ }^{-1}$ ) (B) e da parte aérea (FSa, g.planta ${ }^{-1}$ ) (C) e comprimento do sistema radicular (Cr, mm) (D) de plantas de feijão do genótipo G11, aos 14, 21 e 28 dias após a emergência 

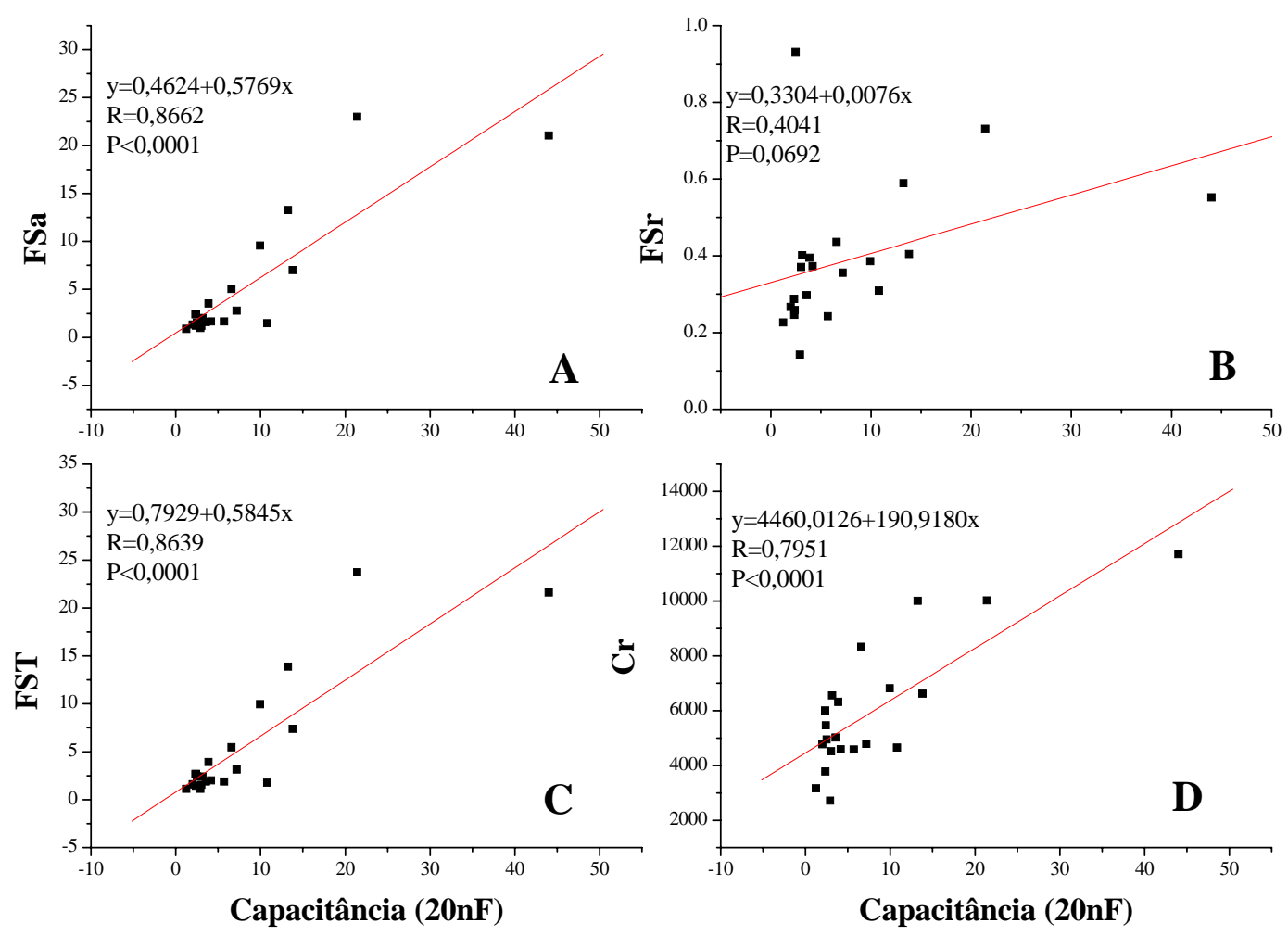

Figura 35 - Correlação entre capacitância e fitomassa seca do sistema radicular $\left(\right.$ FSr, g.planta ${ }^{-1}$ ) (A), total (FST, g.planta ${ }^{-1}$ ) (B) e da parte aérea (FSa, g.planta $^{-1}$ ) (C) e comprimento do sistema radicular (Cr, mm) (D) de plantas de feijão do genótipo G21, aos 14, 21 e 28 dias após a emergência 

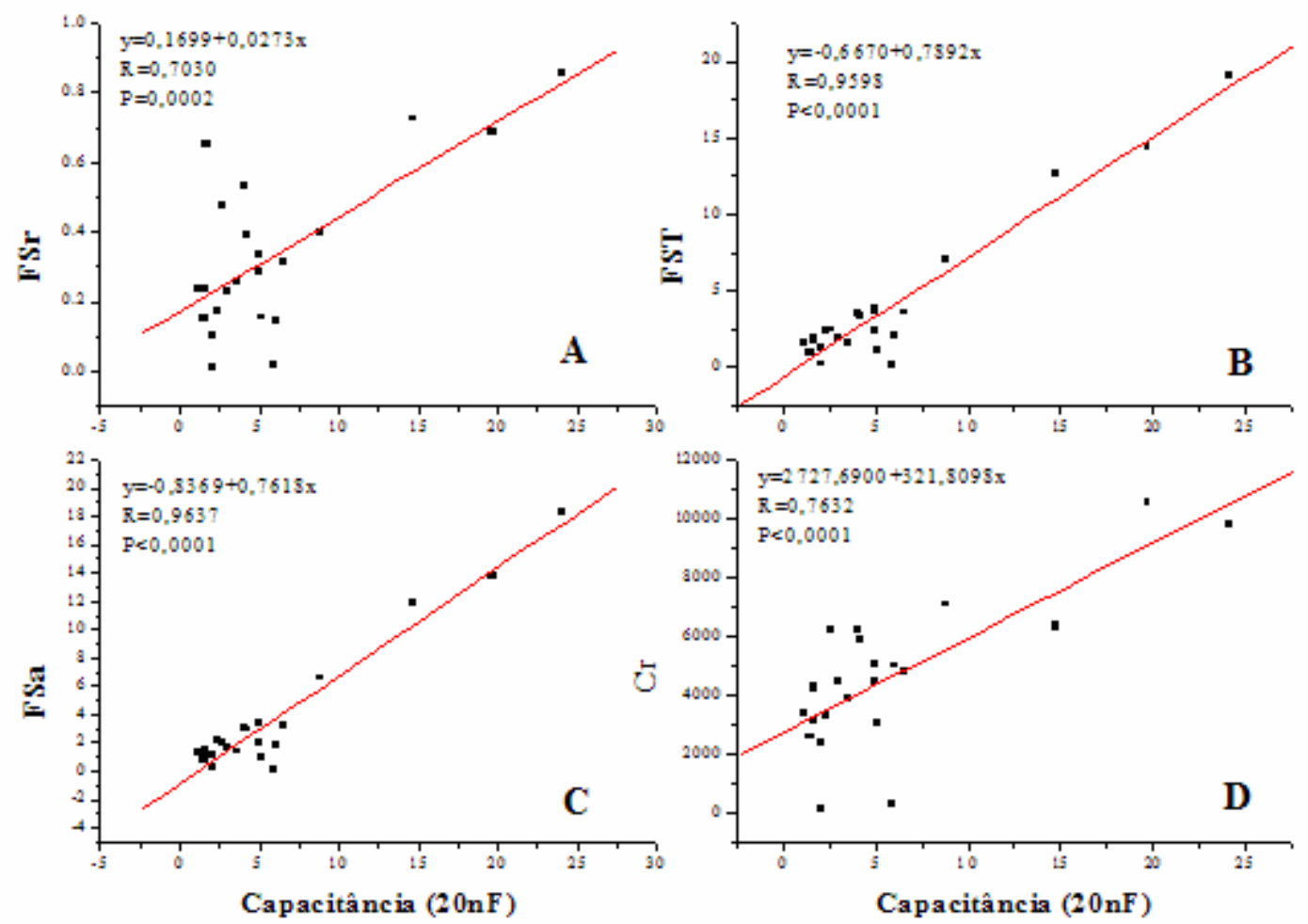

Figura 36 - Correlação entre capacitância e fitomassa seca do sistema radicular (FSr, g.planta $\left.{ }^{-1}\right)(A)$, total (FST, g.planta ${ }^{-1}$ ) (B) e da parte aérea (FSa, g.planta ${ }^{-1}$ ) (C) e comprimento do sistema radicular (Cr, mm) (D) de plantas de feijão do genótipo G57, aos 14, 21 e 28 dias após a emergência

A correlação entre capacitância e respiração inclui as plantas, aos 14 e 28 DAE, em cada um dos genótipos. Essa correlação leva em consideração a parte viva da raiz, e apresenta os valores de coeficiente de correlação mais elevados do que os demais parâmetros do sistema radicular. Essa importante observação confirma a hipótese de que a capacitância avalia a parte viva do sistema radicular (Choupek, 1977; Danton, 1995). 


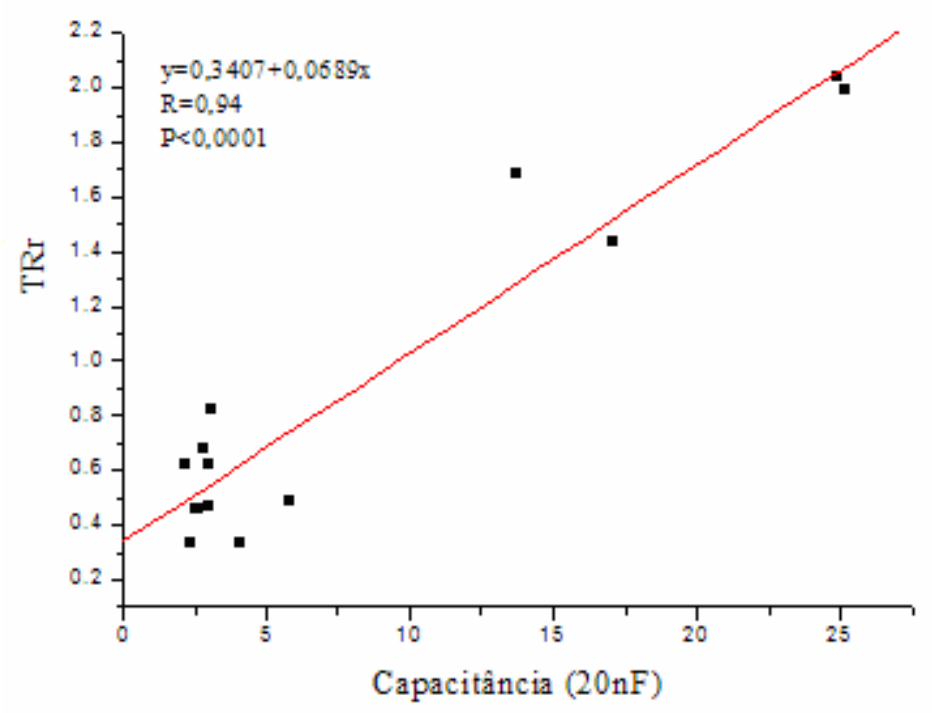

Figura 37 - Correlação entre capacitância e respiração do sistema radicular, de plantas de feijão, do genótipo G6, aos 14 e 28 dias após a emergência

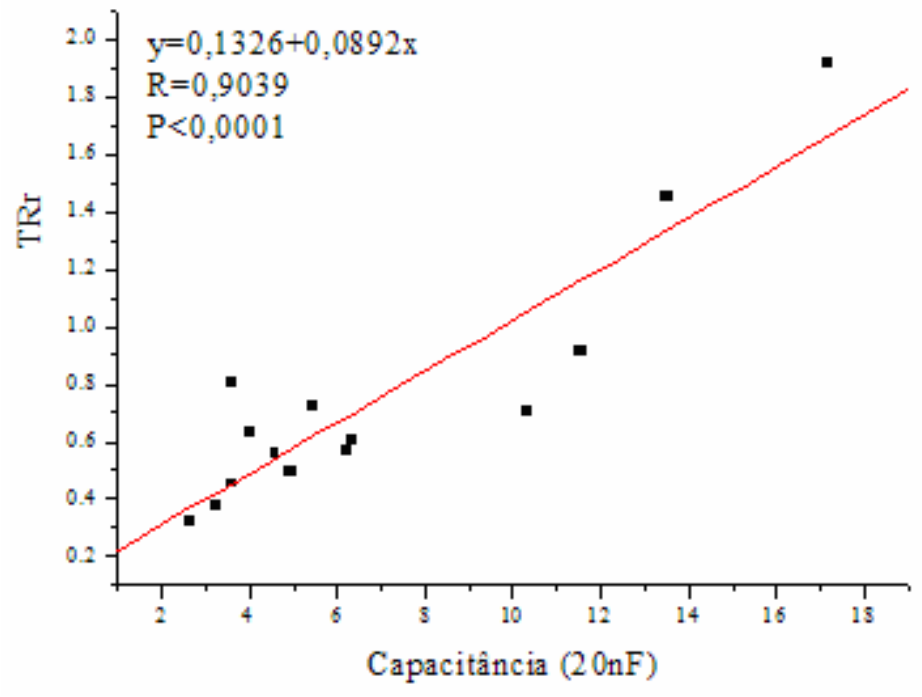

Figura 38 - Correlação entre capacitância e respiração do sistema radicular, de plantas de feijão, do genótipo G11, aos 14 e 28 dias após a emergência 


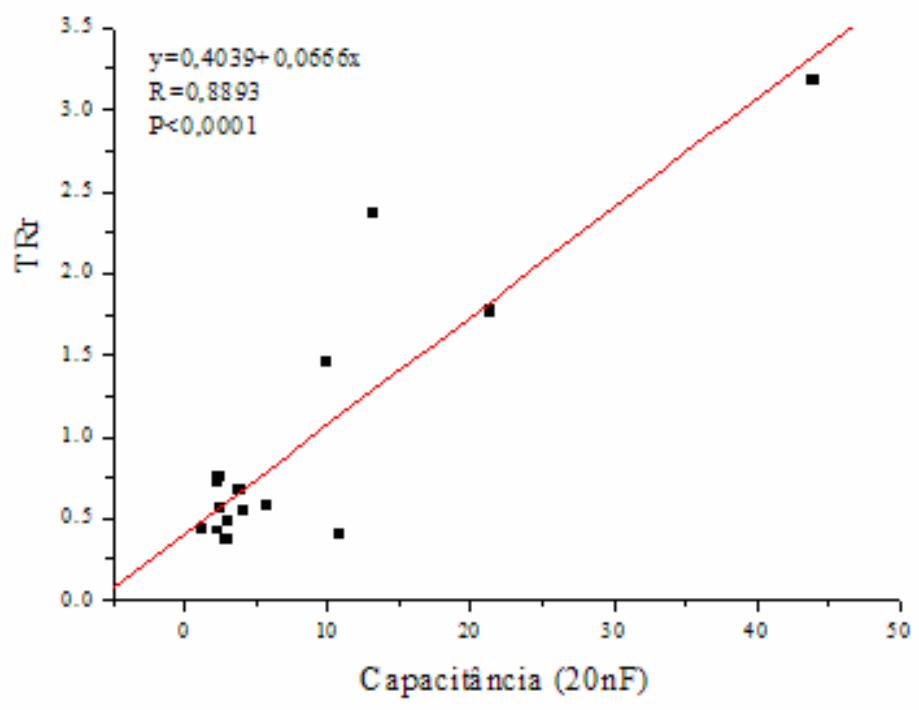

Figura 39- Correlação entre capacitância e respiração do sistema radicular, de plantas de feijão, do genótipo G21, aos 14 e 28 dias após a emergência

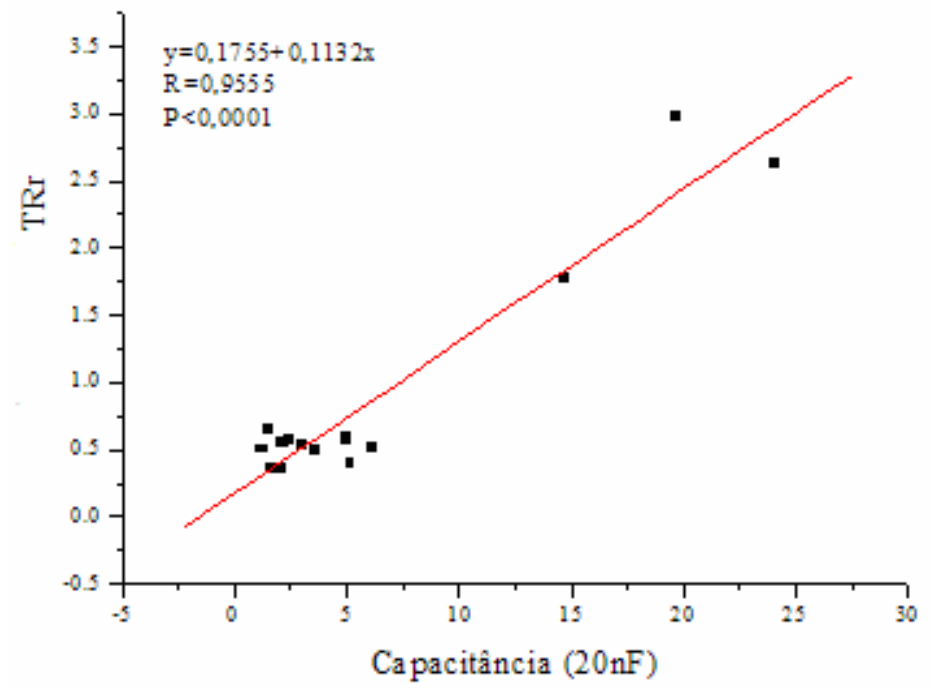

Figura 40 - Correlação entre capacitância e respiração do sistema radicular, de plantas de feijão, do genótipo G57, aos 14 e 28 dias após a emergência 

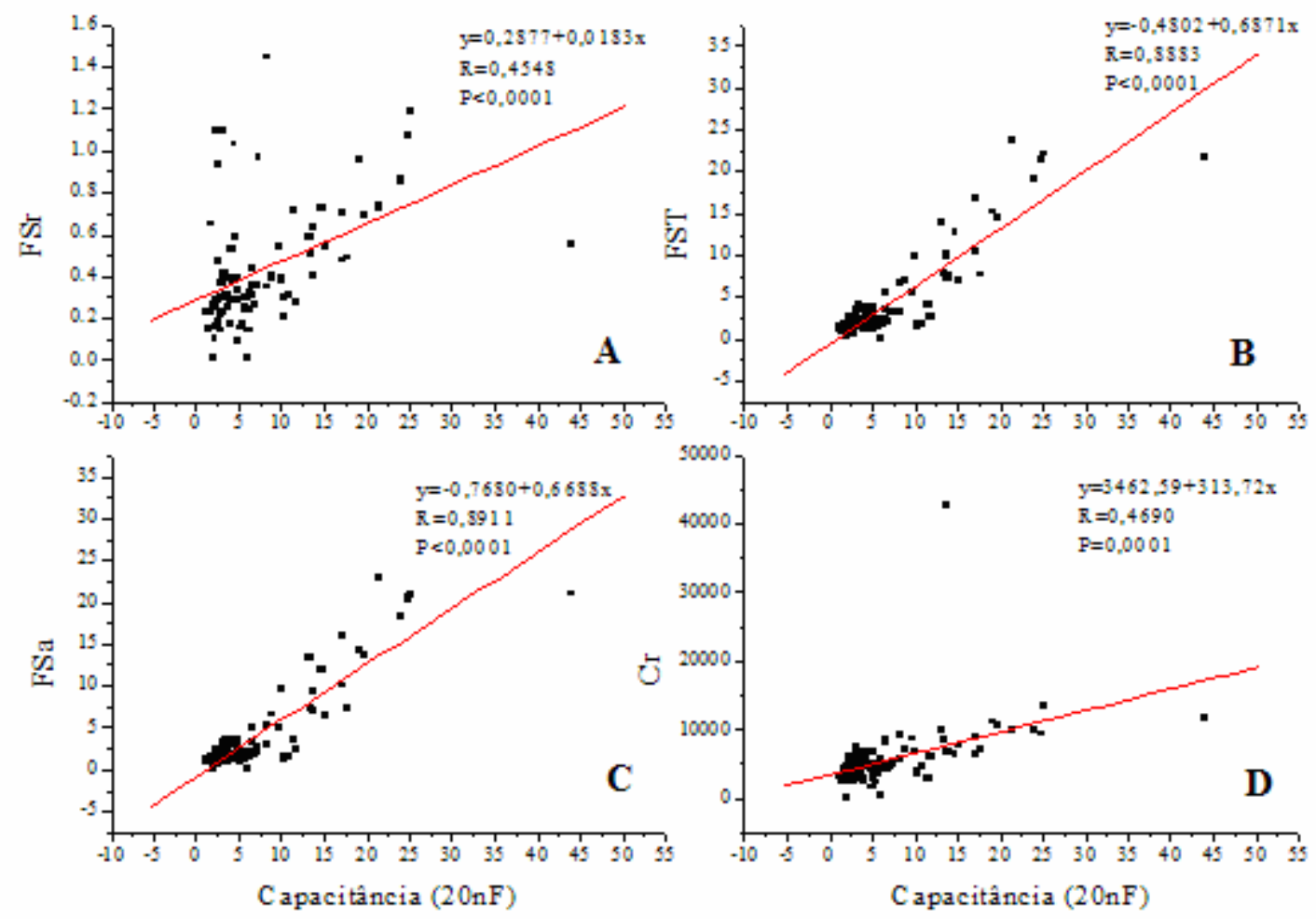

Figura 41 - Correlação entre capacitância e fitomassa seca radicular (FSr, g.planta ${ }^{-1}$ ) (A), fitomassa seca total (FST, g.planta ${ }^{-1}$ ) (B), fitomassa seca de parte aérea (FSa, g.planta ${ }^{-1}$ ) (C) e comprimento do sistema radicular(Cr, mm) (D) dos genótipos de feijoeiro comum (G6, G11, G21 e G57), aos 14, 21 e 28 dias após emergência, sob dose alta (Da) e baixa (Db) de $\mathrm{P}$

As correlações entre capacitância e comprimento radicular, respiração do sistema radicular, fitomassa seca radicular, da parte aérea e total, foram realizadas com os valores médios, de quatro repetições, aos 14, 21 e 28 DAE (Tabela 8). Os diferentes valores de correlação, observados ao longo do tempo, confirmam a existência do efeito do estádio de desenvolvimento (Dalton, 1995) nesse tipo de avaliação. O valor máximo do coeficiente de correlação foi observado aos 28 dias, para todos os parâmetros avaliados. 
Tabela 8. Coeficientes de correlação entre médias de quatro repetições de valores de capacitância $(20 \mathrm{nF})$ e fitomassa seca radicular $\left(\mathrm{FSr}\right.$, g.planta $\left.{ }^{-1}\right)$, fitomassa seca de parte aérea (FSa, g.planta ${ }^{-1}$ ), fitomassa seca total (FST, g.planta ${ }^{-1}$ ), comprimento radicular $(\mathrm{Cr}, \mathrm{cm})$ e respiração do sistema radicular ( $\mu$ mol.min ${ }^{-1} \cdot \mathrm{g}^{-1}$ de $\mathrm{CO}_{2}$ ), aos 14, 21 e 28 dias de quatro genótipos de feijoeiro

\begin{tabular}{cccccc}
\hline DAE & FSr & FSa & FST & Cr & Respiração \\
\hline 14 & 0,42 & 0,64 & 0,55 & 0,39 & 0,72 \\
21 & 0,54 & 0,84 & 0,83 & 0,81 & $\mathrm{~N}^{1}$ \\
28 & 0,78 & 0,99 & 0,99 & 0,77 & 0,98 \\
$14,21,28$ & 0,70 & 0,97 & 0,97 & 0,82 & $0,97^{2}$ \\
\hline
\end{tabular}

${ }^{1} \mathrm{~N}=$ não avaliada.

${ }^{2}$ Valores referentes aos 14 e 28 DAE.

Os resultados apresentados no experimento V sugerem que a avaliação da planta, através de seus valores de capacitância, é uma metodologia promissora, principalmente quando objetiva a avaliação da parte funcional do sistema radicular, e a fitomassa seca total.

\subsection{Experimento VI: efeito do fósforo estratificado no substrato no desenvolvimento do feijoeiro comum}

Nesse experimento foi prevista a análise dos valores de capacitância, a qual não foi incluída em função do medidor de capacitância não estar funcionando bem por ocasião da avaliação.

A Figura 42 ilustra plantas dos diferentes tratamentos por ocasião da avaliação do desenvolvimento vegetativo. A aparência das plantas é semelhante, com exceção do tratamento sem a adição de P. Esse apresentou sintomas visuais típicos de deficiência de P (Taiz \& Zeiger, 2003). 

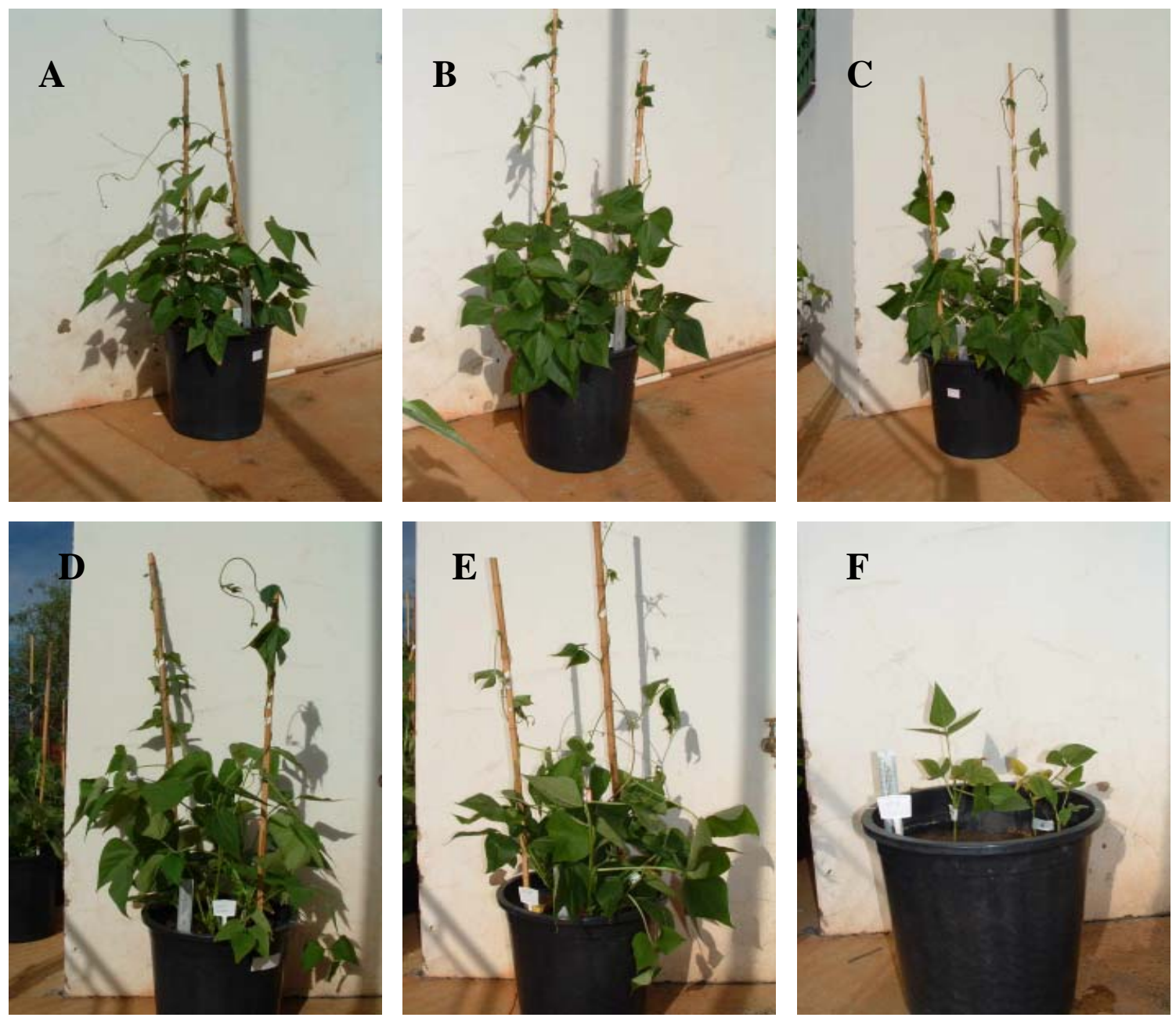

Figura 42 - Plantas de feijão desenvolvidas em diferentes tratamentos com relação ao posicionamento de P no vaso: (A) P distribuído unifomemente no vaso (CP), (B) P na camada de 0-5 cm (S), (C) P na camada de 0-5 cm ditribuído em uma faixa de $10 \mathrm{~cm}$ de largura (SF), (D) P distribuído em faixa na camada de 10-15 cm de profundidade (SSF), (E) P uniformente distribuído na camada de 10-15 cm (SS), e (F) sem adição de P (SP)

Os sintomas de deficiência de P são visíveis, quando o grau de deficiência é severo. Existem graus intermediários de deficiência, onde o diagnóstico é dado através de análise química do tecido. Os teores dos nutrientes da parte aérea foram quantificados (Tabela 9). A quantidade de $\mathrm{P}$ nos tecidos das plantas do tratamento em que o $\mathrm{P}$ não foi 
adicionado foi cerca de três vezes inferior aos demais tratamentos. Esse resultado é confirmado na Tabela 10.

Tabela 9. Resultado da análise do tecido da parte aérea do feijeiro, submetidos aos seis tratamentos, em que CP se refere ao tratamento em que o P foi distribuído uniformemente, SP ao tratamento sem adição de P, SS ao tratamento em que o P foi distribuído unifomemente na camada de $10-15 \mathrm{~cm}$ de profundidade, SSF ao tratamento em que o $\mathrm{P}$ foi distribuído em uma faixa de $10 \mathrm{~cm}$ de largura na camada de $10-15 \mathrm{~cm}$ de profundidade, $\mathrm{S}$ ao tratamento em que o $\mathrm{P}$ foi localizado na camada de 0-5 cm de profundidade, e SF ao tratamento em que o $\mathrm{P}$ foi distribuído em uma faixa de $10 \mathrm{~cm}$ de largura na camada de 0-5 cm de profundidade

\begin{tabular}{cccccccccccc}
\hline Trat & N & P & $\begin{array}{c}\text { K } \\
\text { g.kg }\end{array}$ & Ca & Mg & S & B & Cu & $\begin{array}{c}\text { Fe } \\
\mathrm{mg}^{-1} \mathrm{~kg}^{-1}\end{array}$ & Mn & Zn \\
\hline SS & 31,9 & 4,4 & 26,8 & 22,7 & 13,6 & 4,6 & 88,0 & 3,5 & 352,6 & 108,1 & 30,1 \\
SP & 29,7 & 1,5 & 29,8 & 18,5 & 11,1 & 5,4 & 66,5 & 3,5 & 174,1 & 39,5 & 30,4 \\
SF & 25,8 & 4,7 & 31,4 & 18,8 & 9,4 & 4,3 & 61,4 & 2,9 & 422,7 & 68,0 & 30,8 \\
CP & 22,0 & 3,6 & 25,8 & 20,0 & 11,7 & 4,8 & 63,6 & 2,9 & 148,3 & 42,9 & 20,1 \\
S & 32,3 & 4,3 & 24,5 & 24,8 & 11,4 & 4,3 & 59,3 & 2,8 & 231,4 & 130,2 & 37,4 \\
SSF & 25,3 & 4,4 & 27,5 & 17,4 & 10,8 & 3,5 & 51,0 & 2,9 & 179,3 & 54,0 & 18,6 \\
\hline
\end{tabular}

A Figura 43 ilustra os valores de comprimento radicular (Cr, mm), número de raízes adventícias (Nra), comprimento das raízes na camada de 0 a $15 \mathrm{~cm}$ de profundidade, em relação ao comprimento do sistema radicular todo (CRr, mm) e área radicular $\left(\mathrm{Ar}, \mathrm{mm}^{2}\right)$.

Os resultados mostram que a distribuição do P no solo, dada pelos diferentes tratamentos, proporcionou diferença significativa do comprimento radicular, entre todos os níveis. A diferença é expressa pelas letras que seguem o nome dos tratamentos (que são apresentados em ordem decrescente de valor de comprimento radicular): SSF a, CP ab, S abc, SF bcd, SS cd e SP d. 
Tabela 10. Teor de $\mathrm{P}$ no tecido da parte aérea de plantas de feijão submetidas aos diferentes tratamentos

\begin{tabular}{cccc}
\hline Tratamento & P (repetição 1) & $\begin{array}{c}\text { P (repetição 2) } \\
\text { g.kg-1 }^{-1}\end{array}$ & P (repetição 3) \\
\hline SS & 4,3 & 4,1 & 4,4 \\
SP & 1,4 & 1,5 & 1,4 \\
SF & 4,8 & 4,7 & 4,9 \\
CP & 3,4 & 3,5 & 3,4 \\
S & 4,0 & 4,0 & 4,1 \\
SSF & 4,1 & 4,2 & 4,0 \\
\hline
\end{tabular}

O comprimento elevado do tratamento CP já era previsto. A distruibuição do P é conhecida como moduladora da arqutetura radicular (Snapp et al., 1995; Ho et al, 2004). A distribuição uniforme de $\mathrm{P}$ em $\mathrm{CP}$ conduziu a um elevado $\mathrm{Cr}$. O menor valor de $\mathrm{Cr}$ foi apresentado pelo tramento sem adição de P. Essa resposta é coerente à observada anteriormente por Snaap et al. (1995) em feijoeiro.

A plasticidade fenotípica de um determinado genótipo é dada em resposta a condições ambientais distintas (Ho et al., 2004). O comprimento do sistema radicular quantifica a plasticidade fenotípica desse órgão (Snapp et al., 1995; Lynch \& Beebe, 1995).

A eficiência de um genótipo, em relação ao $\mathrm{P}$, pode ser avaliada pela plasticidade do sistema radicular (Ho et al., 2004). Os tratamentos, aqui empregados, consistiram na simulação de um solo com sítios de alta disponibilidade de P. Os resultados referentes ao comprimento radicular mostratam que, a variedade cultivada Pérola, apresenta o sistema radicular plástico, em relação ao posicionamento da disponibilidade de $\mathrm{P}$ no solo.

A distribuição de $\mathrm{P}$ ao solo interfere no desenvolvimento do sistema radicular (Bates \& Lynch, 1996; Lopes-Bucio et al., 2002), em termos de ramificação, ângulo de crescimento e diâmetro das raízes (Forde \& Lorenzo, 2001). Experimentos no campo e 
em casa-de-vegetação têm demonstrado que a disponibilidade de $\mathrm{P}$ regula o ângulo de crescimento de raízes basais do feijoeiro (Bonser et al., 1996; Liao et al., 2001).

A resposta de crescimento da raiz, em relação à gravidade, pode ser avaliada através do ângulo de crescimento das raízes, ou pela proporção de raízes localizadas nas camadas superficiais, em relação a todo o sistema radicular (Rubio et al., 2003). O comprimento radicular relativo ( $\mathrm{CRr}$, \%) (Figura 43) mostrou que os tratamentos apresentaram efeito significativo sobre o CRr.

A diferença é expressa pelas letras que seguem os nomes dos tratamentos (que foram dispostos em ordem decrescente de CRr): SSF a, CP ab, SF ab, SS ab, SP b e S b. $\mathrm{O}$ tratamento denominado $\mathrm{S}$, em que o $\mathrm{P}$ está posicionado na superfície $(0-5 \mathrm{~cm})$ do vaso, apresentou menor proporção de raiz na camada de 0 a $15 \mathrm{~cm}$. A típica resposta de proliferação de raízes, nos locais onde se concentra o P do feijoeiro comum (Snaap et al., 1995; Borch et al., 1999), sugere que nesse tratamento as raízes se concentraram na camada de 0 a $5 \mathrm{~cm}$.

A Figura 44 mostra que os tratamentos empregados não proporcionaram diferença significativa sobre o número de raízes adventícias. As raízes adventícias exploram a região mais superficial do solo (Rubio et al., 2003). A presença de um tratamento em que o P estava localizado na camada de 0 a $5 \mathrm{~cm}$ não interferiu no Nra. Esse resultado sugere que a variedade cultivada Pérola não responde a disponibilidade de $\mathrm{P}$ através da formação de raízes adventícias, como foi observado em outros genótipos de feijão (Miller, et al., 2003).

A Ar sofreu efeito significativo dos tratamentos: CP a, SSF ab, S bc, SF cd, SS cd e SP d. A área radicular seguiu o mesmo padrão que o comprimento radicular, uma vez que não houve diferença significativa entre o CP e SSP. A área radicular difere do comprimento por levar em consideração a espessura das raízes.

A Figura 44 ilustra o acúmulo de fitomassa no sistema radicular (FSR, g.planta ${ }^{-1}$ ). O efeito significativo dos tratamentos sobre a FSr segue a seguinte sequiência: CP a, SF ab, S ab, SSF cd, SS bc, SP d. Esses resultados são coerentes a estudos anteriores, onde plantas sob baixa disponibidade de $\mathrm{P}$ exibiram menores valores de FSr (Snaap et al., 1995). A diferença significativa dos resultados confirma que a 
disponibilidade de fósforo regula vários processos, como o padrão de distribuição de fitomassa (Lynch, 1995; Nielsen et al., 2001).
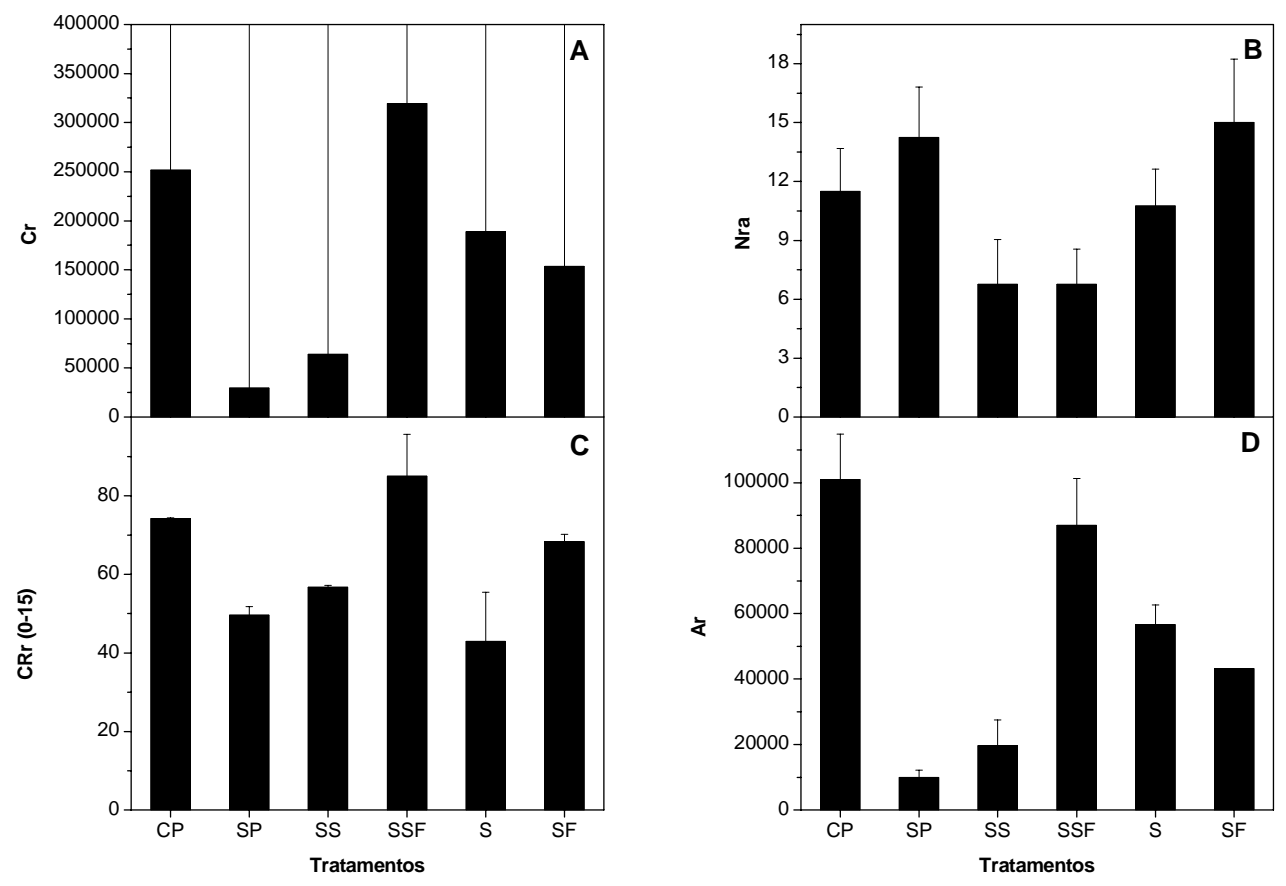

Figura 43 - Comprimento do sistema radicular ( $\mathrm{Cr}, \mathrm{mm})$ (A), número de raízes adventícias (Nra) (B), comprimento relativo de raízes na camada de 0-15 $\mathrm{cm}$ de profundidade (CRr, \%) (C), área do sistema radicular (Ar, $\mathrm{mm}^{2}$ ) (D) de feijoeiro comum, variedade cultivada Pérola, com P (CP), sem P (SP), P localizado na camada de 10-15 cm de profundidade (SS), P localizado em faixa, na camada de 10-15 cm de profundidade (SSF), P localizado na camada de 0-5 cm de profundidade (S) e P localizado, em faixa, na camada de $0-5 \mathrm{~cm}$ de profundidade (SF)

O modelo de distribuição de comprimento, e área radicular, observado para os diferentes tratamentos, diferiu do observado para o acúmulo de fitomassa radicular. 
Duncan \& Ohlrogge (1958) já haviam constatado que a fitomassa seca radicular não fornece informações com relação a exploração do solo pelas raízes, uma vez que não considera a espessura das mesmas. As raízes proliferadas em sítios que apresentam maior disponibilidade e P, geralmente são mais finas (Larigauderie \& Richards, 1994).

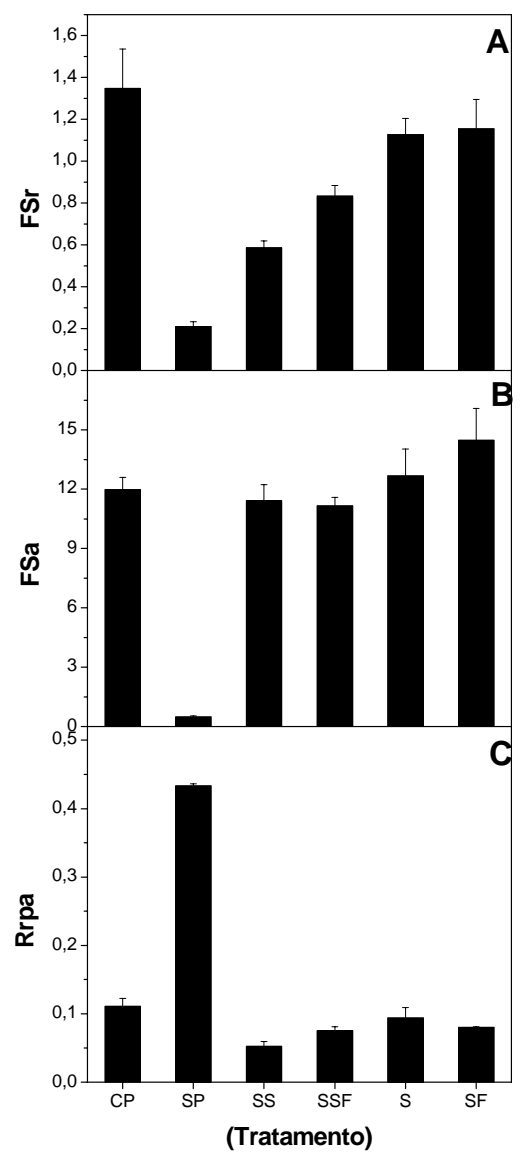

Figura 44 - Fitomassa seca radicular (FSr, g.planta ${ }^{-1}$ ) (A) e de parte aérea (FSa, g.planta $^{-1}$ ) (B) e relação entre raiz e parte aérea de feijoeiro comum (Rrpa) (C), variedade cultivada Pérola, sem P (CP) e com P (SP) localizado na camada de 10-15 cm de profundidade (SS), em faixa, na camada de $10-15 \mathrm{~cm}$ de profundidade (SSF), na superfície (S) e na superfície em faixa (SF) 
Os tratamentos proporcionaram a seguinte diferença significativa sobre a fitomassa seca de parte aérea (FSa, g.planta ${ }^{-1}$ ) (Figura 44): SF a, S ab, CP b, SS b, SSF b, SP c. Do ponto de vista estatítico, a resposta do fitomassa seca de parte aérea dos tratamentos em que o $\mathrm{P}$ foi posicionado na camada de 0 a $5 \mathrm{~cm}$ de profundidade, foi igual quando o $\mathrm{P}$ foi distribuído em toda essa camada (S) ou posicionado apenas em uma faixa de $10 \mathrm{~cm}$ de largura (SF).

Segundo (Terry \& Rao, 1991), a primeira conseqüência da deficiência de P é a redução da superfície foliar, decorrente da menor expansão de folhas novas. De fato, plantas que não receberam a adição de $\mathrm{P}$ ao substrato foram as que apresentaram menores valores de área foliar.
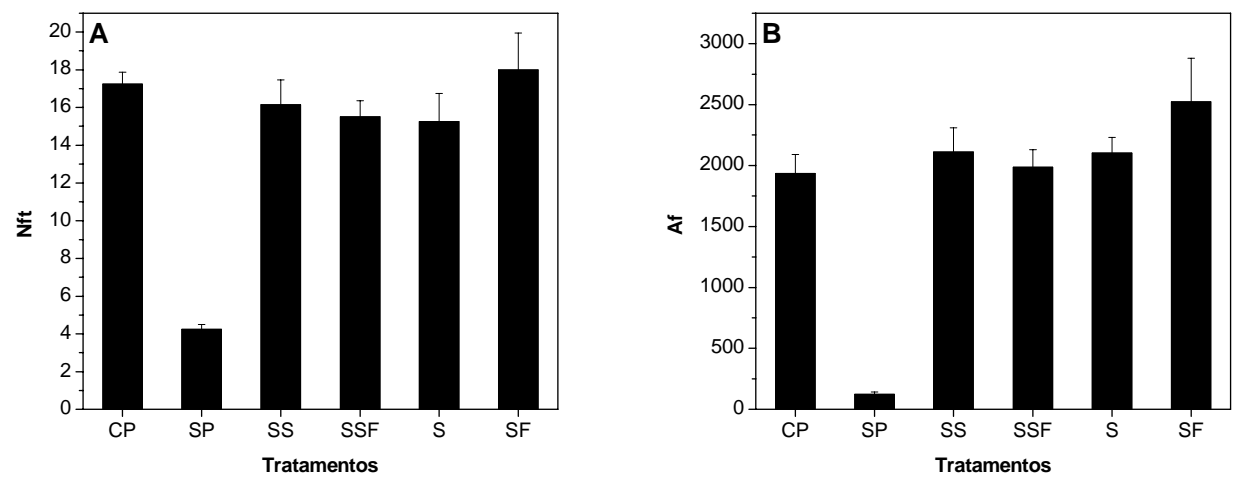

Figura 45 - Número de folhas compostas (Nf) e área radicular (Ar, $\mathrm{mm}^{2}$.planta ${ }^{-1}$ ) de feijoeiro comum, variedade cultivada Pérola, sem P (CP) e com P (SP) localizado na camada de 10-15 cm de profundidade (SS), em faixa, na camada de 10-15 cm de profundidade (SSF), na superfície (S) e na superfície em faixa (SF)

A Rrpa foi significativamente decrescente nos tratamentos: SP a, CP b, S bc, SF bc, SSF bc e S c. O maior valor da relação entre raiz e parte aérea foi observado pelas plantas do tratamento sem adição de P. O crescimento do sistema radicular é mais inibido, em condições de baixa disponibilidade de P, do que o da parte aérea (Freeden et 
al., 1988; Lynch et al., 1992; Snaap et al., 1995), indicando um aumento relativo da fitomassa empregada na de exploração de um maior volume de solo (Jesko, 1994).

Embora os tratamentos tenham apresentado efeito significativo sobre a fitomassa seca de parte aérea (Figura 44), quando este parâmetro é avaliado em termos de número de folhas compostas e área foliar (Figura 45), verifica-se diferença significativa apenas com o tratamento SP, que foi menor que os demais tratamentos.

Características fisiológicas e morfológicas são importantes para determinar a produtividade do feijoeiro, a qual é expressa por três componentes: número de vagens por planta, número de sementes por vagem, e fitomassa seca de sementes (Fageria et al., 1991). A produtividade de grãos é fortemente relacionada à disponibilidade de $\mathrm{P}$ (Araújo \& Teixeira, 2003).

Na Figura 46 são avaliados os componentes da produção número de grãos por planta, fitomassa seca de grãos (FSg, g. planta ${ }^{-1}$ ), duração do ciclo de desenvolvimento (dias) e número de vagens por planta (Nv). Em todos esses aspectos, foi observada diferença significativa entre todos os tratamentos, que são colocados em ordem decrescente (número de grãos): CP, S, SSF, SS, SF e SP. O número de grãos por planta foi superior no tratamento em que o $\mathrm{P}$ foi distribuído uniformemente no vaso.

$\mathrm{O}$ efeito da distribuição de $\mathrm{P}$ sobre a fitomassa seca dos grãos, no entanto, apresentou a seguinte ordem decrescente: S, CP, SSF, SS, SF, SP. Esse parâmetro, de suma importância, mostrou mais favorável quando o $\mathrm{P}$ foi adicionado, uniformemente, à camada de 0 a $5 \mathrm{~cm}$ de profundidade.

A ordem decrescente dos tratmentos em relação ao número de vagens (S, CP, SSF, SF, SS, SP) mostra que esse componente diferiu da fitomassa seca de grãos apenas na ordem dos tratamentos SS e SF.

Em muitas espécies o fósforo interfere no desenvolvimento fenológico (Salisbury \& Ross, 1992). Os resutados mostram que o posionamento desse no solo, também interfere nesse parâmetro. $\mathrm{O}$ ciclo das plantas (dias) decresce signitivamente na seguinte seqüência: SSF, SS, SF, CP, SP e S. O tratamento que proporcionou maior fitomassa seca de grãos e maior número de vagens por planta foi o mesmo que mostrou o menor 
ciclo. Essas observações sugerem que o posionamento do $\mathrm{P}$ na camada de 0 a $5 \mathrm{~cm}$ de profundidade é o mais vantajoso do ponto de vista fitotécnico.
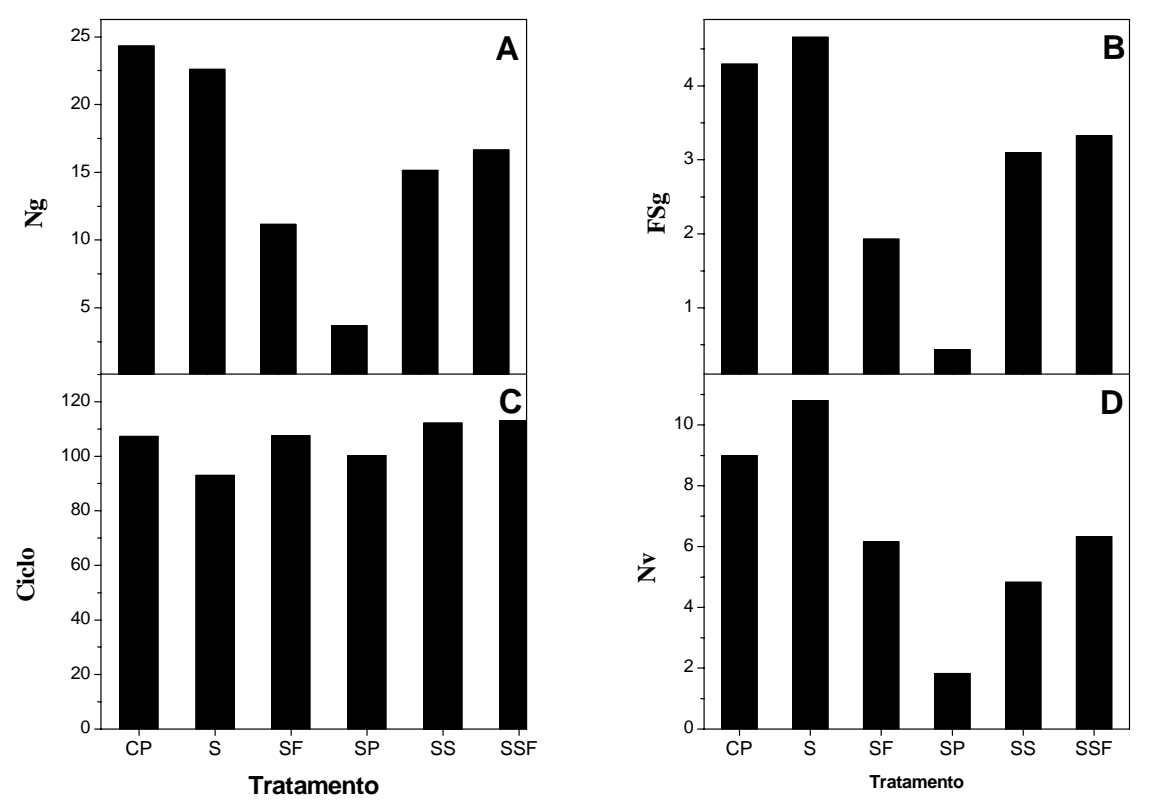

Figura 46 - Número de grãos por planta (Ng) (A), fitomassa seca dos grãos (FSg, g.planta $^{-1}$ ) (B), duração do ciclo (dias) (C) e número de vagens por planta (Nv) (D) do feijoeiro comum, variedade cultivada Pérola, com P (CP) e sem P (SP) localizado na camada de 10 a $15 \mathrm{~cm}$ de profundidade (SS), em faixa, na camada de 10 a $15 \mathrm{~cm}$ de profundidade (SSF), na superfície (S) e na superfície em faixa (SF)

Os baixos valores referentes à produtividade das plantas no tratamento sem adição de P condizem com observações de Marschner (2002). É freqüente em plantas deficientes em P o aborto de flores e a redução do número de vagens (Hall \& Schawartz em Bennette, 1994). Além disto, a fase vegetativa em plantas deficientes em $\mathrm{P}$ é mais lenta, enquanto a fase reprodutiva é atrasada e mais curta (Hall \& Schawartz citados por Bennette, 1994). 
Correlação entre a fitomassa seca de parte aérea e produtividade apresentada por alguns genótipos (Yan et al., 1995b), não ocorreu neste estudo para a variedade cultivada Pérola.

A disponibilidade de recursos (P e água) e a competição entre raízes determinam o desenvolvimento radicular do feijoeiro (Ho et al., 2004).

A escassez de água tem sido associada ao desenvolvimento de sistemas radiculares profundos. A granulometria arenosa, do solo empregado neste estudo, pode ter proporcionado baixa retenção de água, e interferido na distribuição do sistema radicular.

O posicionamento das plantas no vaso simulou a densidade populacional de 240.000 plantas.ha ${ }^{-1}$. Em termos fitotécnicos, essa simulação é positiva, uma vez que, aproxima o estudo das condições reais de campo. No entanto, do ponto de vista fisiológico, dificulta a interpretação dos resultados, em função de ser adicionado aos tratamentos, o efeito da competição entre as plantas do mesmo vaso. O efeito da competição, em nosso estudo, é verificado pelos elevados coeficientes de variação obtidos. Embora, em todos tratamentos tenha sido empregado o mesmo número de plantas por vaso, é difícil avaliar se o efeito da campetição entre plantas foi o mesmo para todos os tratamentos.

A competição por luz é a mais amplamente divulgada. Da mesma forma que na parte aérea, no solo existe competição por recursos pouco disponíveis, entre raízes da mesma planta e de outras plantas. O P, por se tratar de um elemento de baixa mobilidade no solo, tem sua aquisição dependente da exploração do solo pelas raízes (Barbier, 1995), o que intensifica o processo de competição para sua obtenção.

Além disto, a competição é intensificada porque empregamos só um genótipo. Rubio et al. (2001), ao estudarem o efeito da competição sofre o desenvolvimento do sistema radicular do feijoeiro, verificou a existência de competição entre raízes de plantas do mesmo genótipo. 


\section{CONCLUSÕES}

O uso da capacitância é uma opção metodológica para: (i) aferir o crescimento de plantas de feijão em termos de fitomassa seca total, e (ii) avaliar a parte funcional do sistema radicular.

Em condições ótimas de água e fertilidade do solo, a distribuição de fósforo uniformemente na camada superficial (0 a $5 \mathrm{~cm}$ de profundidade) proporciona o aumento dos componentes de produção.

O acúmulo e a partição de fitomassa seca em plantas de feijão são condicionados pela disponibilidade (quantidade e posicionamento) de fósforo no solo. 


\section{REFERÊNCIAS BIBLIOGRÁFICAS}

AGGARWAL, V.D.; MUGHOGHO, R.M.; CHIRWA, R.M.; SNAPP, S. Field-based screening methodology to improve tolerance of common bean to low-P soils. Communication Soil Science Plant Analysis, v.28, p.1623-1632, 1997.

AL-NIEMI, T.S.; KAHN, M.L.; MACDERMOTT, T.R. P metabolism in bean Rhizobium tropici symbiosysis Plant Physiology, v.113, p.1233-1242, 1997.

ARAÚJO, A.P.; TEIXEIRA, M.G.; ALMEIDA, D.L. Variability of traits associated with phosphorus efficiency in wild and cultivated genotypes of common beans. Plant and Soil, v.203, p.173-182, 1998.

ARAÚJO, A.P.; TEIXEIRA, M.G. Nitrogen and phosphorus harvest indeces of common bean cultivars: implication for yield quantity and quality. Plant and Soil, v. 257, p.425-433, 2003.

BARLOW, W.P. The origin, diversity and Biology of shoot-bourne roots. In: DAVIS, D.; HAISSING E. (Ed.). Biology of adventitious root formation. London: Plenum Press, 1994. p.1-23.

BATES, T; LYNCH, J.P. Stimulation of root hair elongation in Arabidopsis thaliana by low phosphorus availability. Plant Cell and Environment, v.19, p.529-538, 1996.

BENNETT, W. Plant nutrient utilization and diagnostic plant symptoms In: BENNETT, W. (Ed.). Nutrient deficiencies \& toxicities in crop plants: 2. ed. St. Paul: Minnesota APS Press, 1994 p.1-7.

BONSER, A.M.; LYNCH, J.P.; SIEGLINDE, S. Effect of phosphorus deficiency on growth angle of basal roots in Phaseolus vulgaris. New Phytologist, v.132, p.281288, 1996. 
BORCH, K.; BOUMA, T.J.; LYNCH, J.P.; BROWN, K.M. Ethylene: A regulator of root architecture response to soil phosphorus availability. Plant Cell and Environment, v.22, p.425-431, 1999.

BOUMA; T.J.; NIELSEN, K.L.; KOUTSTAAT, B. Sample preparation and scanning protocol for computerized analysis of root length and diameter. Plant and Soil, v.218, p.218-196, 2000.

CALDWELL, M.M.; DUDLEY, L.M.; LILIEHOLM, B. Soil solution phosphate, root uptake kinetics and nutrient acquisition: implication for a patchy soil environment. Oecologia, v.89, p.305-309, 1992.

CAMPBELL, A.G.; PHILLIPS, D.S.M.; O`REILLY, E.D. An electronic measurement for pasture yield estimation. Journal of British Grassland Society, v.17, p.89-100, 1962.

CAKMAK, I.; HENGELER, C.; MARSCHNER, H. Changes in phloem export of sucrose in leaves in response to phosphorus, potassium and magnesium deficiency in bean plants. Journal of Experimental Botany, v.45, p.1251-1257, 1994 a.

CAKMAK, I.; HENGELER, C.; MARSHENER, H. Partioning of shoot and root dry carbohydrate in bean plants suffering from phosphorus, potassium and magnesium deficiency. Journal of Experimental Botany, v.45, p.1245-1250, 1994b.

CHOUPEK, O. The relationship between electric capacitance and some other parameters of plant roots. Biologia Plantarum, v.14, p.227-230, 1972.

CHOUPEK, O. Evaluation of the size of a plants root system using its electrical capacitance. Plant and Soil, v.48, p.525-532, 1977.

CHOUPEK, O.; SKÁCEL, M.; EHRENBERGERONA, J. Effect of divergent selection for root size in field-grown alfalfa. Canadian of Journal Plant Science, v.79, p.9395, 1999.

CIERESKO, I.; BARBACHOWSKA, A. Sucrose metabolism in leaves and roots of bean (Phaseolus vulgaris L.) Journal of Plant Physiology, v.156, p.640-644, 2000.

DALTON, F.N. In-situ root extent measurements by electrical capacitance methods. Plant and Soil, v.173, p.157-165, 1995. 
DOURADO NETO, D.; FANCELLI, A.L. Produção de feijão. Guaíba: Agropecuária, 2000. 386p.

DREW, M.C.; SAKER, R.L. Nutrient supply and the growth of seminal root system in Barley. III. Compensatory increase in growth of lateral roots, and in rates of phosphate uptake, in response to a localized supply of phosphate. Journal of Experimental Botany, v. 29, p.435-451, 1978.

EVANS, M.L.; MOORE, R.; HASENSTEIN, K.H. How does roots respond to gravity. Scientific, v.255, p.112-119, 1986.

FAGERIA; N.K.; BALIGAR, V.C.; JONES, C.A. Growth and mineral nutrition on field crops. New York: Marcel Dekker, 1991. 476 p.

FAN, M.; ZHU, J.; RICHARDS, C.; BROWN, K.M.; LYNCH, J.P. Physiological roles of aerenchyma in phosphorus-stressed roots. Functional Plant Biology, v. 30, p.493-506, 2003.

FISHER, M.C.T.; EISSENSTAT, D.M.; LYNCH, J.P. Lack of evidence for programmed root senescence in common bean (Phaseolus vulgaris) grown at different levels of phosphorus supply. New Phytologist, v.153, p.63-71, 2002.

FÖHSER, D.; CLAASSEN, N.; JUNGK, A. Phosphorus efficiency of plants. I. External and internal requirement and $\mathrm{P}$ uptake efficiency of different plant species. Plant and Soil, v.110, p.101-109, 1988.

FORDE, B.; LORENZO, H. The nutritional control of the root development. Plant and Soil, v.232, p.51-68, 2001.

FREDEEN, A.L.; RAO, I.M., TERRY, N. Influence of phosphorus nutrition on growth and carbon partioning in Glycine max. Plant Physiology, v.89, p.225-230, 1989.

FRIEND, A.L; COLEMAN, M.D.; ISEBRANDS, J.G. Carbon allocation to root and shoot systems of woody plants. In: DAVIS, D., HAISSING E. (Ed.) Biology of adventitious root formation. London: Plenum Press, 1994. p.245-273.

FUCHS, Y; MATTOO, A.K.; CHALUTZ, E.; ROT, I. Biosynthesis of ethylene in higher plants: the metabolic site of inhibition by phosphate. Plant, Cell and Environment, v.4, p.291-295. 1981. 
GASPARIKÓVÁ, O. Root metabolism. In: KOLEK, J.; KOZINKA, V. Physiology of the plant root system. Dordrecht: Kluwer Academic, 1992. p.82-128.

GE, Z.; RUBIO, G.; LYNCH, J.P. The importance of root gravitropism for inter-root competition and phosphorus acquisition efficiency: Results from a geometric simulation model. Plant and Soil, v.218, p.159-171, 2000.

GEPTS, P.; FERNÁNDEZ, F. Etapas del desarrollo de la planta de frijol comun (Phaseolus vulgaris L.). Cali: Centro Internacional de Agricultura Tropical, 1982. 10p.

GONZÁLEZ, A.; LYNCH, J.P.; TOHME, J.M.; BEEBE, S.E.; MACCHIAVELLI, R.E. Characters related to leaf photosynthesis in wild populations and landraces of common bean. Crop Science, v.35, p.1468-1476, 1995.

GROSS, K.L.; PETERS, A.; PREGITZER, K.S. Fine root growth and demographic responses to nutrient patches in four old-field plant species. Oecologia, v.95, p.6164. 1993.

HALL, R.; SCHWARTZ, H.F. Common bean. In: BENNETT, W. (Ed.) Nutrient deficiencies \& toxicities in crop plants. 2. ed. St. Paul: APS Press, 1994. p143147.

HALSTED, M.; LYNCH, J.P. Phosphorus response of C3 and C4 species. Journal of Experimental Botany, v. 47, p.497-505, 1996.

HE, C.J.; MORGAN, P.W.; DREW, M. Enranced sensivity to ethylene in nitrogen- or phosphate-starved roots of Zea mays L. during aerenchyma formation. Plant Physiology, v.98, p.137-142, 1992.

HEERAMAN, D.A.; HOPMANS, J.W.; CLAUSNITZER, V. Three-dimensional imaging of plant roots in situ with X-ray Computed tomography. Plant and Soil, v.188, p.167-179, 1997.

HINSINGER, P. Biologyavailability of soil inorganic P in the rhizosphere as affected by root-induced chemical changes: a review. Plant and Soil. v.237, p.173-195, 2001.

HO, M.D.; MCCANNON, B.C.; LYNCH, J.P. Otimization modeling of plant root architecture for water and phosphorus acquisition. Journal of Theoretical Biology, v. 226, p.331-340, 2004. 
HORST, W.J; KAMH, M; JIBRIN, J.M; CHUDE, V.O. Agronomic measurements for increasing P availability to crops. Plant and Soil v.237, p.211-223, 2001.

HOLFORD, I.C.R. Soil phosphorus: its measurement, and its uptake by plants. Australian Journal of Soil Research, v.35, p.227-239, 1997.

JACKSON, M.B. Are plant hormones involved in root to shoot communication? Adv. Botany Research, v.19, p.3-7, 1993.

JACKSON, R.B.; CALDWELL, M.M. The timing and degree of root proliferation in fertile-soil microsites for three cold-desert perennial. Oecologia, v. 81, p.149-153, 1998.

JESKO, T. The root as an integral part of the plant. KOLEK, J.; KOZINKA, V. (Ed.) Physiology of the plant root system. Dordrecht: Kluwer Academic, p.1-30, 1994.

JOHNSON, I.R. Plant respiration in relation to growth, maintenance, ion uptake and nitrogen assimilation. Plant Cell Environment, v.13, p.319-328, 1990.

KENDALL, W.A.; PEDERSON, G. A.; HILL, R.R. Root size estimates of red clover and alfalfa based on electrical capacitance and root diameter measurements. Grass Forage Science, v.37, p.253-256, 1982.

KOLEK, J.; HOLOBRADA, M. Ions uptake and transport. KOLEK, J.; KOZINKA, V. (Ed.) Physiology of the plant root system. Dordrecht: Kluwer Academic, 1992. p.204-285.

LARIGAURDERIE, A.; RICHARDS, J.H. Root proliferation characteristics of seven perennial arid-land grasses in nutrient-enriched microsites. Oecologia, v.99, p.102111, 1994.

LIAO, H.; RUBIOLOGY, G.; YAN, X.; CAO, A.; BROWN, K.M.; LYNCH, J.P. Effect of phosphorus availability on basal root shallowness in common bean. Plant and Soil, v.232, p.69-79, 2001.

LÓPEZ-BUCIO, J.L.; MARTÍNEZ DE LA VEJA, O; GUEVARA-GARCÍA, A.; HERRERA-ESTRELLA L. Enhance phosphorus uptake in transgenic tabacco plants that overproduce citrate. Natural Biotechnology, v.18, p.450-453, 2000. 
LÓPEZ-BUCIO, J.L.; HERNÁNDEZ-ABREU, E.; SÁNCHEZ-CALDERÓN, L.; NIETO-JACOBO M.F.; SIMPSON, J.; HERRERA-ESTRELLA, L. Phosphate availability alters architecture and causes changes in hormone sensitivity in the Arabidopsis root system. Plant Physiology, v.129, p.244-256, 2002.

LYNCH, J.P. Root architecture and plant productivity. Plant Physiology, v.109, p.7-13, 1995.

LYNCH, J.P. The role of nutrient-efficient crops in modern agriculture. Journal Crop of Production, v.1, p.241-264, 1998.

LYNCH, J.P.; BEEBE, S.E. Adaptation of beans (Phaseolus vulgaris) to low phosphorus availability. Horticultural Science, v.30, p.1165-1171, 1995.

LYNCH, J.P.; BROWN, K.M. Ethylene an plant response to nutritional stress. Physiologia Plantarum, v.100, p.613-619, 1997.

LYNCH, J.P.; BROWN, K.M. Topsoil foraging: an architectural adaptation to low phosphorus availability. Plant and Soil, v.237, p.225-237, 2001.

LYNCH, J.P.; GONZÁLEZ, A.; TOHME, J.M.; GARCIA, J.A. Variation in characters to leaf photosynthesis in wild bean populations. Crop Science. v.32, p.933-640, 1992.

LYNCH, J.P.; RODRIGUEZ, N.S.H. Photosyntetic nitrogen-use efficiency in relation to leaf longevity in common bean. Crop Science, v.34, p.1284-1290, 1994.

LYNCH, J.P.; VAN BEEM, J. Growth and architecture of seedling roots of common bean genotypes. Crop Science, v.33, p.1253-1257, 1993.

MA, Z.; BIELENBERG, D.F.; BROWN, K.M.; LYNCH, J.P. Regulation of root hair density by phosphorus availability in Arabidopsis thaliana. Plant, Cell and Environmental, v.24, p.459-467, 2001.

MACCULLY, M. How do real roots work? Plant Physiology, v.109, 1-6p. 1997.

MARSCHENER, H. Mineral nutrition of higher plants. San Diego: Academic Press, 2002. 889p.

MILLER, C. Root architecture of common bean (Phaseolus vulgaris L.): adaptive nature and dynamic response to low phosphorus. State College, 1998. Thesis (Ms) Pennsylvania State University. 
MILLER, C.; NIELSEN, K.L.; LYNCH, J.P.; BECK, D. Adventitious root response in field grown common bean: A possible adaptive strategy to low phosphorus conditions. In: FLORES H., LYNCH, J.P.; EISSENSTAT, D. (Ed.). Radical Biology: Advances and Perspectives on the function of plant roots. Rockville: American Society of Plant Physiologists, 1998. p.394-396.

MILLER, C.; OCHOA, I; NIELSEN, K.L.; BECK, D; LYNCH, J.P. Genetic variation for adventitious rooting in response to low phosphorus availablity: potential utility for phosphorus availability: potential utility for phosphorus acquisition from stratified soils. Functional Plant Biology, v. 30, p.973-985, 2003.

NEUMANN, G.; MASSONNEAU, A.; MARTINOIA, E.; RÖMHELD, V. Physiological adaptations to phosphorus deficiency during proteoid development in white lupin. Planta, v.208, p.373-382, 1999.

NIELSEN, K.L.; BOUMA, T.; LYNCH, J.P.; EISSENSTAT, D. Effects of phosphorus availability and vesicular-arbuscular mycorrizas on carbon budget of common beans (Phaseolus vulgaris). New Phytologist, v.138, p.647-656, 1998.

NIELSEN, K.L.; MILLER, C. R.; BECK, D.; LYNCH, J.P. Fractal geometry of root system: Field observations of contrasting genotype of common bean (Phaseolus vulgaris L.) grown under different phosphorus regimes. Plant and Soil, v.206, p.181-190, 1999.

NIELSEN, K.L.; ESHEL, A.; LYNCH, J.P. The effect of P availability on the carbon economy of contrasting common bean (Phaseolus vulgaris) genotypes. Journal of Experimental Botany, v.52, p.329-339, 2001.

NOBEL, P.S. Physicochemical and environmental plant physiology. San Diego: Academic Press, 1991. 635p.

PEREIRA, P.A.A.; BLISS, F.A. Nitrogen fixation and plant growth of common Bean (Phaseolus vulgaris L.).at different levels of phosphorus availability. Plant and Soil, v.104, p.79-84, 1987.

POLLOCK, D.J.; FARRAR, J.F.; GORDON, A.J. Carbon partioning within and between organisms. Oxford: BIOLOGYS Scientific,. 1992. 258p. 
POTHULURI, J.V.; KISSEL, D.E.; WHITNEY, D.A.; THIEN, S.J. Phosphorus uptake from soil layers having different soil test phosphorus levels. Agronomy Journal, v.78, p.991-994, 1986.

RAGOthamA, K.G. Phosphate acquisition. Annual Review of Plant Physiology and Molecular Biology, v.50, p.665-693, 1999.

ROBINSON, D. The responses of plants to non-uniform supplies of nutrients. Plant Phytologist, v.127, p.635-679, 1994.

ROBINSON, D. Variation, co-ordination and compensation in root system in relation to soil variability. Plant and Soil, v.187, p.57-66, 1996a.

ROBINSON, D. Resource capture by localized root proliferation: why do plants bother? Annals of Botany, v.77, p.179-185, 1996b.

RUBIO, G.; WALK, T.; GE, Z.Y.; YAN, X.; LIAO, H.; LYNCH, J.P. Root gravitropism and belowground competition among neighboring plants: a modeling approach. Annals of Botany, v.88, p.929-940, 2001.

RUBIO, G.; LIAO, H.; YAN, X.; LYNCH, J.P. Topsoil foraging and its role in plant competitiveness for phosphorus in common bean. Crop Science, v.43, p.598-607, 2003.

SALISBURY, F.B; ROSS, C.W. Plant physiology. 4. ed. Belmont: Wadsworth, 1991. $682 p$.

SCHACHTMAN, D.P.; REID, R.J.; AYLING, S.M. Phosphorus uptake by plants: from soil to cell. Plant Physiology, v. 116, p.147-453, 1998.

SNAPP, S.S.; KOIDA, R.; LYNCH, J.P. Exploitation of localized phosphorus patches by common bean roots. Plant and Soil, v.177, p.211-218, 1995.

SNAPP, S.S.; LYNCH, J.P. Phosphorus distribution and mobilization in bean plants influenced by phosphorus nutrition. Crop Science, v.36, p.929-935, 1996.

STILL, M.; SCHEIBLE, W.R. Understanding allocation to shoot and root growth will require molecular information about which compounds act as signals for the plant nutrient status, and how meristem activity and cellular growth are regulated. Plant and Soil, v.201, p.259-263, 1998.

TAIZ, L.; ZEIGER, E. Plant physiology, Sunderland: Sinauer Associates, 2003. 690p. 
TERRY, N.; RAO, I.M. Nutrient and photosynthesis: iron and phosphorus as case studies. PORTER, J.R.; LAWLOR, D.W (Ed.) Plant growth: interactions with nutrition and environment. Cambridge: Cambridge University Press, 1991, p.56-74.

VAN BEEM, J.; SMITH, M.E.; ZOBEL, R.W. Estimating root mass in using a portable capacitance meter. Agronomy Journal, v.90, p.566-570, 1998.

VAN NOORDWIJK, M.; DE WILLIGEN, J.; EHLERT, P.A.I.; CHARDON, W.J. A simple model of $\mathrm{P}$ by crops as a possible basis for fertilizer recommendations. Netherlands Journal Agriculture Science, v.38, p.317-332, 1990.

WILLIAMSON, L.; RIBRIOUX, S.; FITTER, A.; LEYSER, O. Phosphate availability regulates root system architecture in Arabidopsis. Plant Physiology, v.126, p.1-8, 2001.

YAN, X.; BEEBE, E.S.; LYNCH, J.P. Genetic variation for phosphorus efficiency of common bean in contrasting soil types: yield response. Crop Science, v.35, p.10941099, 1995.

ZAITER, H.Z.; SAADE, M. Interactive effects of salinity and phosphorus nutrition on tepary and common beans cultivars. Communications in Soil Science and Plant Analysis, v.24, p.109-123, 1993. 
APÊNDICE 
Tabela 11. Análise de variância referente à fitomassa seca relativa de raiz (\%) (genótipo G6). Experimento V

\begin{tabular}{ccccc}
\hline Causas da variação & G.L. & S.Q. & Q.M. & F \\
\hline fator A (tempo) & 2 & 511,5098 & 255,7549 & $3,6177 \mathrm{~ns}$ \\
fator B (dose de P) & 1 & 1357,3600 & 1357,3600 & $19,2001^{* *}$ \\
fator A x B & 2 & 16,7816 & 8,3908 & $0,1187 \mathrm{~ns}$ \\
tratamentos & 5 & 1885,6514 & 377,1303 & \\
blocos & 3 & 591,5357 & 197,1786 & $2,7891 \mathrm{~ns}$ \\
resíduo & 15 & 1060,4337 & 70,6956 & \\
\hline
\end{tabular}

Desvio padrão: 8,4081. Média geral:.18,8238. Coeficiente de variação:.44,6673 * Significativo a 5\%. ** Significativo a 1\%. NS: Não Significativo

Tabela 12. Teste de Tukey referente à fitomassa seca relativa de raiz (\%) (genótipo G6) (fator A tempo). Experimento V

\begin{tabular}{cc}
\hline Tratamento & Média \\
\hline 1 & 24,3975 a \\
2 & 18,9813 a \\
3 & 13,0925 a \\
\hline
\end{tabular}

DMS(TUKEY) $=10,9098$

Tabela 13. Teste de Tukey referente à fitomassa seca relativa de raiz (\%) (genótipo G6) (fator B dose de P). Experimento V

\begin{tabular}{cc}
\hline Tratamento & Média \\
\hline 2 & $26,3442 \mathrm{a}$ \\
1 & $11,3033 \mathrm{~b}$ \\
\hline
\end{tabular}


Tabela 14. Análise de variância referente à fitomassa seca relativa de raiz (\%) (genótipo G11). Experimento V

\begin{tabular}{ccccc}
\hline Causas da variação & G.L. & S.Q. & Q.M. & F \\
\hline fator A (tempo) & 2 & 210,6350 & 105,3000 & $6,4333^{* *}{ }^{* *}$ \\
fator B (dose de P) & 1 & 239,9705 & 239,9705 & $14,6585^{*}$ \\
fator A x B & 2 & 46,4958 & 23,2479 & $1,4201 \mathrm{~ns}$ \\
tratamentos & 5 & 497,1019 & 99,4204 & \\
blocos & 3 & 19,7522 & 6,5841 & $0,4022 \mathrm{~ns}$ \\
resíduo & 15 & 245,5619 & 16,3708 & \\
\hline
\end{tabular}

Desvio padrão: 4,0461. Média geral: 13,2954. Coeficiente de variação:.30,4322 * Significativo a 5\%. ** Significativo a 1\%. NS: Não Significativo

Tabela 15. Teste de Tukey referente à fitomassa seca relativa de raiz (\%) (genótipo G11) (fator A tempo). Experimento V

\begin{tabular}{cc}
\hline Tratamento & Média \\
\hline 1 & $17,3275 \mathrm{a}$ \\
2 & $12,2650 \mathrm{ab}$ \\
3 & $10,2938 \mathrm{~b}$ \\
\hline
\end{tabular}

DMS(TUKEY) $=5,2500$

Tabela 16. Teste de Tukey referente à fitomassa seca relativa de raiz (\%) (genótipo G11) (fator B dose de P). Experimento V

\begin{tabular}{cc}
\hline Tratamento & Média \\
\hline 2 & $16,4575 \mathrm{a}$ \\
1 & $10,1333 \mathrm{~b}$ \\
\hline
\end{tabular}


Tabela 17. Análise de variância referente à fitomassa seca relativa de raiz (\%) (genótipo G21). Experimento V

\begin{tabular}{ccccc}
\hline Causas da variação & G.L. & S.Q. & Q.M. & F \\
\hline fator A (tempo) & 2 & 183,5135 & 91,7567 & $2,3116 \mathrm{~ns}$ \\
fator B (dose de P) & 1 & 506,0071 & 506,0017 & $12,7475^{* *}$ \\
fator A x B & 2 & 62,4523 & 31,2262 & $0,7867 \mathrm{~ns}$ \\
tratamentos & 5 & 751,9675 & 150,3935 & \\
blocos & 3 & 41,5065 & 13,8355 & $0,3486 \mathrm{~ns}$ \\
resíduo & 15 & 595,4151 & 39,6943 & \\
\hline
\end{tabular}

Desvio padrão: 6,3003. Média geral: 13,1775 Coeficiente de variação:.47,8114 * Significativo a 5\%. ** Significativo a $1 \%$. NS: Não Significativo

Tabela 18. Teste de Tukey referente à fitomassa seca relativa de raiz (\%) (genótipo G21) (fator A tempo). Experimento V

\begin{tabular}{cc}
\hline Tratamento & Média \\
\hline 1 & 16,8938 a \\
2 & 12,3738 a \\
3 & 10,2650 a \\
\hline
\end{tabular}

DMS $($ TUKEY $)=8,1750$

Tabela 19. Teste de Tukey referente à fitomassa seca relativa de raiz (\%) (genótipo G21) (fator B dose de P). Experimento V

\begin{tabular}{cc}
\hline Tratamento & Média \\
\hline 2 & $17,7692 \mathrm{a}$ \\
1 & $8,5858 \mathrm{~b}$ \\
\hline
\end{tabular}


Tabela 20. Análise de variância referente à fitomassa seca relativa de raiz (\%) (genótipo G57). Experimento V

\begin{tabular}{ccccc}
\hline Causas da variação & G.L. & S.Q. & Q.M. & F \\
\hline fator A (tempo) & 2 & 218,4413 & 109,2206 & $3,1650 \mathrm{~ns}$ \\
fator B (dose de P) & 1 & 196,6537 & 196,6537 & $5,6986^{*}$ \\
fator A x B & 2 & 1,9645 & 0,9822 & $0,0285 \mathrm{~ns}$ \\
tratamentos & 5 & 417,0595 & 83,4119 & \\
blocos & 3 & 68,8296 & 22,9432 & $0,6648 \mathrm{~ns}$ \\
resíduo & 15 & 517,6355 & 34,5090 & \\
\hline
\end{tabular}

Desvio padrão: 5,8744. Média geral:.11,3617 Coeficiente de variação:.51,7040 * Significativo a 5\%. ** Significativo a 1\%. NS: Não Significativo

Tabela 21. Teste de Tukey referente à fitomassa seca relativa de raiz (\%) (genótipo G57) (fator A tempo). Experimento V

\begin{tabular}{cc}
\hline Tratamento & Média \\
\hline 1 & $15,0188 \mathrm{a}$ \\
2 & $11,4363 \mathrm{a}$ \\
3 & $7,6300 \mathrm{a}$ \\
\hline
\end{tabular}

DMS(TUKEY) $=7,6223$

Tabela 22. Teste de Tukey referente à fitomassa seca relativa de raiz (\%) (genótipo G57) (fator B dose de P). Experimento V

\begin{tabular}{cc}
\hline Tratamento & Média \\
\hline 2 & $14,2242 \mathrm{a}$ \\
1 & $8,4992 \mathrm{~b}$ \\
\hline
\end{tabular}


Tabela 23. Análise de variância referente à taxa de respiração radicular $\left(\mu\right.$ mol.min ${ }^{-1} \cdot \mathrm{g}^{-1}$ de $\left.\mathrm{CO}_{2}\right)$ do genótipo G6. Experimento V

\begin{tabular}{ccccc}
\hline Causas da variação & G.L. & S.Q. & Q.M. & F \\
\hline fator A (tempo) & 1 & 1,7804 & 1,7804 & $2,3622 \mathrm{~ns}$ \\
fator B (dose de P) & 1 & 0,5879 & 0,5879 & $0,7800 \mathrm{~ns}$ \\
fator A x B & 1 & 0,2448 & 0,2448 & $0,3248 \mathrm{~ns}$ \\
tratamentos & 3 & 2,6130 & 0,8710 & \\
blocos & 3 & 2,4787 & 0,8262 & $1,0963 \mathrm{~ns}$ \\
resíduo & 9 & 6,7831 & 0,7537 & \\
\hline
\end{tabular}

Desvio padrão: 0,8681. Média geral: 1,9117. Coeficiente de variação: 45,4129. * Significativo a 5\%. ** Significativo a 1\%. NS: Não Significativa

Tabela 24. Análise de variância referente à taxa de respiração radicular $\left(\mu\right.$ mol.min ${ }^{-1} \cdot \mathrm{g}^{-1}$ de $\left.\mathrm{CO}_{2}\right)$ do genótipo G11. Experimento V

\begin{tabular}{ccccc}
\hline Causas da variação & G.L. & S.Q. & Q.M. & F \\
\hline fator A (tempo) & 1 & 0,1630 & 0,1630 & $0,1895 \mathrm{~ns}$ \\
fator B (dose de P) & 1 & 1,8494 & 1,8494 & $2,1504 \mathrm{~ns}$ \\
fator A x B & 1 & 5,7995 & 5,7995 & $6,7435^{*}$ \\
tratamentos & 3 & 7,8119 & 2,6040 & \\
blocos & 3 & 4,6183 & 1,5394 & $1,7900 \mathrm{~ns}$ \\
resíduo & 9 & 7,7402 & 0,8600 &
\end{tabular}

Desvio padrão: 0,9274. Média geral: 2,4237. Coeficiente de variação: 38,2627. * Significativo a 5\%. ** Significativo a 1\%. NS: Não Significativa

Tabela 25. Teste de Tukey referente à taxa de respiração radicular $\left(\mu \mathrm{mol} \cdot \mathrm{min}^{-1} \cdot \mathrm{g}^{-1}\right.$ de $\left.\mathrm{CO}_{2}\right)$ do genótipo G11. Experimento V. Fator B (dose de P) dentro do Fator A1 (14 DAE)

\begin{tabular}{cc}
\hline Tratamento & Média \\
\hline 2 & $2,5246 \mathrm{a}$ \\
1 & $2,3228 \mathrm{a}$ \\
\hline
\end{tabular}


Tabela 26. Teste de Tukey referente à taxa de respiração radicular $\left(\mu \mathrm{mol} \cdot \mathrm{min}^{-1} \cdot \mathrm{g}^{-1}\right.$ de $\left.\mathrm{CO}_{2}\right)$ do genótipo G11. Experimento V. Fator B (dose de P) dentro do Fator A2 (28 DAE)

\begin{tabular}{cc}
\hline Tratamento & Média \\
\hline 1 & $2,7637 \mathrm{a}$ \\
2 & $2,0837 \mathrm{a}$ \\
\hline
\end{tabular}

DMS(TUKEY) $=1,0492$

Tabela 27. Análise de variância referente à taxa de respiração radicular $\left(\mu \operatorname{mol} . \mathrm{min}^{-1} \cdot \mathrm{g}^{-1}\right.$ de $\left.\mathrm{CO}_{2}\right)$ do genótipo G21. Experimento V

\begin{tabular}{ccccc}
\hline Causas da variação & G.L. & S.Q. & Q.M. & F \\
\hline fator A (tempo) & 1 & 3,9664 & 3,9664 & $5,6330^{*}$ \\
fator B (dose de P) & 1 & 9,0344 & 9,0344 & $12,8305^{* *}$ \\
fator A x B & 1 & 1,2620 & 1,2620 & $1,7922 \mathrm{~ns}$ \\
tratamentos & 3 & 14,2627 & 4,7542 & \\
blocos & 3 & 3,5009 & 1,1670 & $1,6573 \mathrm{~ns}$ \\
resíduo & 9 & 6,3372 & 0,7041 &
\end{tabular}

Desvio padrão: 0,8391. Média geral: 2,4619. Coeficiente de variação: 34,0844. * Significativo a 5\%. ** Significativo a 1\%. NS: Não Significativa

Tabela 28. Teste de Tukey referente à taxa de respiração radicular $\left(\mu\right.$ mol.min ${ }^{-1} \cdot \mathrm{g}^{-1}$ de $\left.\mathrm{CO}_{2}\right)$ do genótipo G21. Experimento V. Fator A (tempo)

\begin{tabular}{cc}
\hline Tratamento & Média \\
\hline 2 & $2,9598 \mathrm{a}$ \\
1 & $1,9640 \mathrm{~b}$ \\
\hline
\end{tabular}

DMS(TUKEY) $=0,9494$

Tabela 29. Teste de Tukey referente à à taxa de respiração radicular $\left(\mu \mathrm{mol} \cdot \mathrm{min}^{-1} \cdot \mathrm{g}^{-1}\right.$ de $\left.\mathrm{CO}_{2}\right)$ do genótipo G21. Experimento V. Fator B (dose de P)

\begin{tabular}{cc}
\hline Tratamento & Média \\
\hline 1 & $3,2133 \mathrm{a}$ \\
2 & $1,7105 \mathrm{~b}$
\end{tabular}


Tabela 30. Análise de variância referente à taxa de respiração radicular $\left(\mu\right.$ mol.min ${ }^{-1} \cdot \mathrm{g}^{-1}$ de $\left.\mathrm{CO}_{2}\right)$ do genótipo G57. Experimento V

\begin{tabular}{ccccc}
\hline Causas da variação & G.L. & S.Q. & Q.M. & F \\
\hline fator A & 1 & 0,1069 & 0,1069 & $0,0714 \mathrm{~ns}$ \\
fator B & 1 & 0,3814 & 0,3814 & $0,2549 \mathrm{~ns}$ \\
fator A x B & 1 & 0,7070 & 0,7070 & $0,4727 \mathrm{~ns}$ \\
tratamentos & 3 & 1,1953 & 0,3984 & \\
blocos & 3 & 11,8477 & 3,9492 & $2,6401 \mathrm{~ns}$ \\
resíduo & 9 & 13,4629 & 1,4959 &
\end{tabular}

Desvio padrão: 1,2231. Média geral: 2,7653. Coeficiente de variação: 44,2292. * Significativo a 5\%. ** Significativo a 1\%. NS: Não Significativa

Tabela 31. Análise de variância referente à taxa de respiração radicular $\left(\mu \mathrm{mol} \cdot \mathrm{min}^{-1} \cdot \mathrm{m}^{-1}\right.$ de $\left.\mathrm{CO}_{2}\right)$ do genótipo G11. Experimento V

\begin{tabular}{ccccc}
\hline Causas da variação & G.L. & S.Q. & Q.M. & F \\
\hline fator A (tempo) & 1 & 0,0001 & 0,0001 & $5,2359^{*}$ \\
fator B (dose de P) & 1 & 0,0001 & 0,0001 & $3,7429 \mathrm{~ns}$ \\
fator A x B & 1 & 0,0000 & 0,0000 & $1,0431 \mathrm{~ns}$ \\
tratamentos & 3 & 0,0003 & 0,0001 & \\
blocos & 3 & 0,0003 & 0,0001 & $4,2267^{*}$ \\
resíduo & 9 & 0,0002 & 0,0000 & \\
\hline
\end{tabular}

Desvio padrão: 0,0051. Média geral: 0,0179. Coeficiente de variação: 28,4035. * Significativo a 5\%. ** Significativo a 1\%. NS: Não Significativa

Tabela 32. Teste de Tukey referente à taxa de respiração radicular $\left(\mu \mathrm{mol} \cdot \mathrm{min}^{-1} \cdot \mathrm{m}^{-1}\right.$ de $\left.\mathrm{CO}_{2}\right)$ do genótipo G11. Experimento V. Fator A (tempo)

\begin{tabular}{cc}
\hline Tratamento & Média \\
\hline 2 & $0,0208 \mathrm{a}$ \\
1 & $0,0150 \mathrm{~b}$ \\
\hline
\end{tabular}


Tabela 33. Teste de Tukey referente à taxa de respiração radicular $\left(\mu \mathrm{mol} \cdot \mathrm{min}^{-1} \cdot \mathrm{m}^{-1}\right.$ de $\left.\mathrm{CO}_{2}\right)$ do genótipo G11. Experimento V. Fator B (dose de P)

\begin{tabular}{cc}
\hline Tratamento & Média \\
\hline 2 & $0,0204 \mathrm{a}$ \\
1 & $0,0155 \mathrm{a}$ \\
\hline
\end{tabular}

DMS(TUKEY) $=0,0058$

Tabela 34. Análise de variância referente à taxa de respiração radicular $\left(\mu \mathrm{mol} \cdot \mathrm{min}^{-1} \cdot \mathrm{m}^{-1}\right.$ de $\left.\mathrm{CO}_{2}\right)$ do genótipo G21. Experimento V

\begin{tabular}{ccccc}
\hline Causas da variação & G.L. & S.Q. & Q.M. & F \\
\hline Fator A (tempo) & 1 & 0,0001 & 0,0001 & $19,7862^{* *}$ \\
Fator B (dose de P) & 1 & 0,0002 & 0,0002 & $29,3187^{* *}$ \\
fator A x B & 1 & 0,0001 & 0,0001 & $14,3579^{* *}$ \\
tratamentos & 3 & 0,0003 & 0,0003 & \\
blocos & 3 & 0,0000 & 0,0000 & $1,6024 \mathrm{~ns}$ \\
resíduo & 9 & 0,0000 & 0,0000 &
\end{tabular}

Desvio padrão: 0,0023. Média geral: 0,0146. Coeficiente de variação: 15,5839. * Significativo a 5\%. ** Significativo a 1\%. NS: Não Significativa

Tabela 35. Teste de Tukey referente à taxa de respiração radicular $\left(\mu \mathrm{mol} \cdot \mathrm{min}^{-1} \cdot \mathrm{m}^{-1}\right.$ de $\left.\mathrm{CO}_{2}\right)$ do genótipo G21. Experimento V. Fator B (dode de P) dentro de Fator A1 (14 DAE)

\begin{tabular}{cc}
\hline Tratamento & Média \\
\hline 2 & $0,0171 \mathrm{a}$ \\
1 & $0,0121 \mathrm{~b}$
\end{tabular}

DMS(TUKEY) $=0,0026$

Tabela 36. Teste de Tukey referente à taxa de respiração radicular $\left(\mu \mathrm{mol} \cdot \mathrm{min}^{-1} \cdot \mathrm{m}^{-1}\right.$ de $\left.\mathrm{CO}_{2}\right)$ do genótipo G21. Experimento V. Fator B (dode de P) dentro de Fator A2 (28 DAE)

\begin{tabular}{cc}
\hline Tratamento & Média \\
\hline 1 & $0,0177 \mathrm{a}$ \\
2 & $0,0115 \mathrm{~b}$
\end{tabular}


Tabela 37. Análise de variância referente à taxa de respiração radicular $\left(\mu \mathrm{mol} \cdot \mathrm{min}^{-1} \cdot \mathrm{m}^{-1}\right.$ de $\left.\mathrm{CO}_{2}\right)$ do genótipo G57. Experimento V

\begin{tabular}{ccccc}
\hline Causas da variação & G.L. & S.Q. & Q.M. & F \\
\hline fator A (tempo) & 1 & 0,0002 & 0,0002 & $16,0592^{* *}$ \\
fator B (dose de P) & 1 & 0,0000 & 0,0000 & $2,3517 \mathrm{~ns}$ \\
fator A x B & 1 & 0,0003 & 0,0003 & $25,9328^{* *}$ \\
tratamentos & 3 & 0,0005 & 0,0002 & \\
blocos & 3 & 0,0001 & 0,0000 & $1,5009 \mathrm{~ns}$ \\
resíduo & 9 & 0,0001 & 0,0000 &
\end{tabular}

Desvio padrão: 0,0035. Média geral: 0,0185. Coeficiente de variação: 18,7196. * Significativo a 5\%. ** Significativo a 1\%. NS: Não Significativa

Tabela 38. Teste de Tukey referente à taxa de respiração radicular $\left(\mu \mathrm{mol} \cdot \mathrm{min}^{-1} \cdot \mathrm{m}^{-1}\right.$ de $\left.\mathrm{CO}_{2}\right)$ do genótipo G57. Experimento V. Fator B (dose de P) dentro do Fator A1 (14 DAE)

\begin{tabular}{cc}
\hline Tratamento & Média \\
\hline 2 & $0,0219 \mathrm{a}$ \\
1 & $0,0150 \mathrm{~b}$ \\
\hline
\end{tabular}

DMS(TUKEY) $=0,0039$

Tabela 39. Teste de Tukey referente à taxa de respiração radicular $\left(\mu \mathrm{mol} \cdot \mathrm{min}^{-1} \cdot \mathrm{m}^{-1}\right.$ de $\left.\mathrm{CO}_{2}\right)$ do genótipo G57. Experimento V. Fator B (dose de P) dentro do Fator A2 (28 DAE)

\begin{tabular}{cc}
\hline Tratamento & Média \\
\hline 1 & $0,0198 \mathrm{a}$ \\
2 & $0,0171 \mathrm{a}$ \\
\hline
\end{tabular}


Tabela 40. Análise de variância referente à taxa de respiração $\left(\mu \mathrm{mol} \cdot \mathrm{min}^{-1} \cdot \mathrm{g}^{-1}\right.$ de $\left.\mathrm{CO}_{2}\right)$ aos $14 \mathrm{DAE}$ dos genótipos G6, G11, G21 e G57. Experimento V

\begin{tabular}{ccccc}
\hline Causas da variação & G.L. & S.Q. & Q.M. & F \\
\hline fator A (dose de P) & 1 & 3,7314 & 3,7314 & $3,0245 \mathrm{~ns}$ \\
fator B (genótipo) & 3 & 7,0204 & 2,3401 & $1,8968 \mathrm{~ns}$ \\
fator A x B & 3 & 6,9844 & 2,3281 & $1,8871 \mathrm{~ns}$ \\
tratamentos & 7 & 17,73615 & 2,5337 & \\
blocos & 3 & 1,1905 & 0,3968 & $0,3217 \mathrm{~ns}$ \\
resíduo & 21 & 25,9076 & 1,2337 & \\
\hline
\end{tabular}

Desvio padrão: 1,1107. Média geral: 2,1786. Coeficiente de variação: 50,9831. * Significativo a 5\%. ** Significativo a 1\%. NS: Não Significativa

Tabela 41. Análise de variância referente à taxa de respiração $\left(\mu \mathrm{mol} \cdot \mathrm{min}^{-1} \cdot \mathrm{g}^{-1}\right.$ de $\left.\mathrm{CO}_{2}\right)$ aos $28 \mathrm{DAE}$ dos genótipos G6, G11, G21 e G57. Experimento V

\begin{tabular}{ccccc}
\hline Causas da variação & G.L. & S.Q. & Q.M. & F \\
\hline fator A (dose de P) & 1 & 13,1127 & 13,1127 & $74,4040^{* *}$ \\
fator B (genótipos) & 3 & 0,3352 & 0,1117 & $0,6339 \mathrm{~ns}$ \\
fator A x B & 3 & 0,8132 & 0,2711 & $1,5381 \mathrm{~ns}$ \\
tratamentos & 7 & 14,2611 & 2,0373 & \\
blocos & 3 & 1,2890 & 0,4297 & $2,4379 \mathrm{~ns}$ \\
resíduo & 21 & 3,7010 & 0,1762 &
\end{tabular}

Desvio padrão: 0,4198. Média geral: 1,2824. Coeficiente de variação: 32,7354. * Significativo a 5\%. ** Significativo a 1\%. NS: Não Significativa

Tabela 42. Teste de Tukey referente à taxa de respiração ( $\mu \mathrm{mol} \cdot \mathrm{min}^{-1} \cdot \mathrm{g}^{-1}$ de $\left.\mathrm{CO}_{2}\right)$ aos $28 \mathrm{DAE}$ dos genótipos G6, G11, G21 e G57. Experimento V. Fator A (dose de P)

\begin{tabular}{cc}
\hline Tratamento & Média \\
\hline 1 & $1,9226 \mathrm{a}$ \\
2 & $0,6423 \mathrm{~b}$ \\
\hline
\end{tabular}


Tabela 43. Análise de variância referente à relação raiz parte aérea dos genótipos G6, G11, G21 e G57 aos 28 DAE. Experimento V

\begin{tabular}{ccccc}
\hline Causas da variação & G.L. & S.Q. & Q.M. & F \\
\hline Fator A (dose de P) & 1 & 0,1426 & 0,1426 & $8,7876^{* *}$ \\
Fator B (genótipo) & 3 & 0,0332 & 0,0111 & $0,6816 \mathrm{~ns}$ \\
fator A x B & 3 & 0,0581 & 0,0194 & $1,1929 \mathrm{~ns}$ \\
tratamentos & 7 & 0,2339 & 0,0334 & \\
blocos & 3 & 0,0385 & 0,0128 & $0,7899 \mathrm{~ns}$ \\
resíduo & 21 & 0,3408 & 0,0162 & \\
\hline
\end{tabular}

Desvio padrão: 0,1274. Média geral: 0,1274. Coeficiente de variação: 99,9692. * Significativo a 5\%. ** Significativo a 1\%. NS: Não Significativa

Tabela 44. Teste de Tukey referente à relação raiz parte aérea dos genótipos G6, G11, G21 e G57 aos 28 DAE. Experimento V

\begin{tabular}{cc}
\hline Tratamento & Média \\
\hline 2 & $0,1942 \mathrm{a}$ \\
1 & $0,0607 \mathrm{~b}$ \\
\hline
\end{tabular}

DMS(TUKEY) $=0,0937$

Tabela 45. Teste de Tukey referente à relação raiz parte aérea dos genótipos G6, G11, G21 e G57 aos 28 DAE. Experimento V

\begin{tabular}{cc}
\hline Tratamento & Média \\
\hline 1 & $0,1730 \mathrm{a}$ \\
3 & $0,1373 \mathrm{a}$ \\
2 & $0,1146 \mathrm{a}$ \\
& $0,0849 \mathrm{a}$
\end{tabular}


Tabela 46. Análise de variância referente ao comprimento radicular específico (mm.g ${ }^{-1}$ ) aos 28 DAE dos genótipos G6, G11, G21 e G57. Experimento V

\begin{tabular}{ccccc}
\hline Causas da variação & G.L. & S.Q. & Q.M. & F \\
\hline Fator A (dose de P) & 1 & 12180616,6020 & 12180616,6020 & $50,4322 * *$ \\
Fator B (genótipo) & 3 & 568225,2316 & 189408,4105 & $0,7842 \mathrm{~ns}$ \\
fator A x B & 3 & 554759,1173 & 184919,7058 & $0,7656 \mathrm{~ns}$ \\
tratamentos & 7 & 13303600,9509 & 1900514,4216 & \\
blocos & 3 & 919321,3045 & 306440,4348 & $1,2688 \mathrm{~ns}$ \\
resíduo & 21 & 5072018,1691 & 241524,6747 & \\
\hline
\end{tabular}

Desvio padrão: 491,4516. Erro padrão da média: 245,7258. Média geral: 1287,1156. Coeficiente de variação: 38,1824. * Significativo a 5\%. ** Significativo a $1 \%$.

Tabela 47. Teste de Tukey referente ao comprimento radicular específico (mm.g $\left.{ }^{-1}\right)$ aos 28 DAE dos genótipos G6, G11, G21 e G57. Experimento V. Fator A (dose de P)

\begin{tabular}{cc}
\hline Tratamento & Média \\
\hline 2 & 1904,0794 a \\
1 & 670,1519 b \\
\hline
\end{tabular}

DMS(TUKEY)=361,3924

Tabela 48. Teste de Tukey referente ao comprimento radicular específico (mm.g $\left.{ }^{-1}\right)$, aos 28 DAE dos genótipos G6, G11, G21 e G57. Experimento V. Fator B (genótipo)

\begin{tabular}{cc}
\hline Tratamento & Média \\
\hline 1 & 1484,5050 a \\
3 & 1283,8675 a \\
2 & 1271,3150 a \\
4 & 1108,7750 a \\
\hline
\end{tabular}


Tabela 49. Análise de variância referente ao comprimento radicular relativo (\%), aos 28 DAE dos genótipos G6, G11, G21 e G57. Experimento V

\begin{tabular}{|c|c|c|c|c|}
\hline Causas da variação & G.L. & S.Q. & Q.M. & $\mathrm{F}$ \\
\hline Fator A (dose de P) & 1 & 271006089,0670 & 271006089,0670 & $1,4540 \mathrm{~ns}$ \\
\hline Fator B (genótipo) & 3 & --- & 466935273,2987 & 2,5053 ns \\
\hline fator A x B & 3 & --- & 628914698,4958 & $3,3743 *$ \\
\hline tratamentos & 7 & --- & 508365143,4930 & \\
\hline blocos & 3 & --- & 360460916,8464 & $1,9340 \mathrm{~ns}$ \\
\hline resíduo & 21 & --- & 186382532,9078 & \\
\hline \multicolumn{5}{|c|}{$\begin{array}{l}\text { Tabela 50. Teste de Tukey referente ao comprimento radicular relativo (\%), aos } 28 \text { DAE dos } \\
\text { genótipos G6, G11, G21 e G57. Experimento V. Fator B (genótipo) dentro do fator A1 } \\
\text { (dose alta de P) }\end{array}$} \\
\hline \multicolumn{2}{|c|}{ Tratamento } & \multicolumn{3}{|c|}{ Média } \\
\hline \multicolumn{2}{|c|}{1} & \multicolumn{3}{|c|}{45029,2475 a } \\
\hline \multicolumn{2}{|c|}{3} & \multicolumn{3}{|c|}{17392,2725 b } \\
\hline \multicolumn{2}{|c|}{2} & \multicolumn{3}{|c|}{$11330,2075 \mathrm{~b}$} \\
\hline \multicolumn{2}{|c|}{4} & \multicolumn{3}{|c|}{9464,2325 b } \\
\hline
\end{tabular}

DMS $($ TUKEY $)=26914,3348$

Tabela 51. Teste de Tukey referente ao comprimento radicular relativo (\%), aos 28 DAE dos genótipos G6, G11, G21 e G57. Experimento V. Fator B (genótipo) dentro do fator A2 (dose baixa de P)

\begin{tabular}{cc}
\hline Tratamento & Média \\
\hline 3 & 15824,9725 a \\
4 & 15751,7675 a \\
2 & 15285,6625 a \\
1 & 13072,4025 a \\
\hline
\end{tabular}


Tabela 52. Teste de Tukey referente ao comprimento radicular relativo (\%), aos 28 DAE. Experimento V. Fator A (dose de P) dentro do fator B1 (genótipo G6)

\begin{tabular}{cc}
\hline Tratamento & Média \\
\hline 1 & 45029,2475 a \\
2 & 13072,4025 b
\end{tabular}

DMS(TUKEY) $=20078,4839$

Tabela 53. Teste de Tukey referente ao comprimento radicular relativo (\%), aos 28 DAE. Experimento V. Fator A (dose de P) dentro do fator B2 (genótipo G11)

\begin{tabular}{cc}
\hline Tratamento & Média \\
\hline 2 & 15285,6625 a \\
1 & 11330,2075 a \\
\hline
\end{tabular}

DMS(TUKEY) $=20078,4839$

Tabela 54. Teste de Tukey referente ao comprimento radicular relativo (\%), aos 28 DAE. Experimento V. Fator A (dose de P) dentro do fator B3 (genótipo G21)

\begin{tabular}{cc}
\hline Tratamento & Média \\
\hline 1 & 17392,2725 a \\
2 & 15824,9725 a \\
\hline
\end{tabular}

DMS(TUKEY) $=20078,4839$

Tabela 55. Teste de Tukey referente ao comprimento radicular relativo (\%), aos 28 DAE. Experimento V. Fator A (dose de P) dentro do fator B4 (genótipo G57)

\begin{tabular}{cc}
\hline Tratamento & Média \\
\hline 2 & 15751,7675 a \\
1 & 9464,2325 a \\
\hline
\end{tabular}


Tabela 56. Análise de variância referente ao comprimento das raízes adventícias. Experimento V

\begin{tabular}{ccccc}
\hline Causas da variação & G.L. & S.Q. & Q.M. & F \\
\hline Fator A (dose de P) & 1 & 35588215,2376 & 35588215,2376 & $12,3144 * *$ \\
Fator B (genótipo) & 3 & 17898709,0599 & 5966236,3533 & $2,0645 \mathrm{~ns}$ \\
fator A x B & 3 & 7072701,7546 & 2357567,2515 & $0,8158 \mathrm{~ns}$ \\
tratamentos & 7 & 60559626,0521 & 8651375,1503 & \\
blocos & 3 & 2518223,9185 & 839407,9728 & $0,2905 \mathrm{~ns}$ \\
resíduo & 21 & 60689498,9520 & 2889976,1406 & \\
\hline
\end{tabular}

Desvio padrão: 1699,9930 Erro padrão da média: 849,9965. Média geral: 3081,1372. Coeficiente de variação: 55,1742.

* Significativo a 5\%. ** Significativo a $1 \%$.

Tabela 57. Teste de Tukey referente ao comprimento das raízes adventícias. Experimento V. Fator A (dose de P)

\begin{tabular}{ccc}
\hline Tratamento & Média \\
\hline 1 & 4135,7138 a \\
2 & $2026,5606 \mathrm{~b}$ \\
\hline
\end{tabular}

DMS(TUKEY) $=1250,1020$

Tabela 58. Análise de variância referente ao comprimento de raízes relativo (\%). Experimento V

\begin{tabular}{ccccc}
\hline Causas da variação & G.L. & S.Q. & Q.M. & F \\
\hline Fator A (dose de P) & 1 & 88,2788 & 88,2788 & $1,2998 \mathrm{~ns}$ \\
Fator B (genótipo) & 3 & 641,2312 & 213,7437 & $3,1471 *$ \\
fator A x B & 3 & 271,8878 & 90,6293 & $1,3344 \mathrm{~ns}$ \\
tratamentos & 7 & 1001,3978 & 143,0568 & \\
blocos & 3 & 1416,4365 & 472,1455 & $6,9517 * *$ \\
resíduo & 21 & 1426,2791 & 67,9181 &
\end{tabular}

Desvio padrão: 8,2412. Erro padrão da média: 4,1206. Média geral: 74,1866. Coeficiente de variação: 11,1088. * Significativo a $5 \%$. ** Significativo a $1 \%$. 
Tabela 59. Teste de Tukey referente ao comprimento de raízes relativo (\%). Experimento V. Fator B (genótipo)

\begin{tabular}{cc}
\hline Tratamento & Média \\
\hline 4 & $79,7825 \mathrm{a}$ \\
2 & $75,9188 \mathrm{ab}$ \\
1 & $73,6037 \mathrm{ab}$ \\
3 & $67,4413 \mathrm{~b}$
\end{tabular}

DMS(TUKEY) $=11,4884$

Tabela 60. Análise de variância referente ao comprimento radicular (mm) total. Experimento V

\begin{tabular}{ccccc}
\hline Causas da variação & G.L. & S.Q. & Q.M. & F \\
\hline Fator A (dose de P) & 1 & 298326706,8601 & 298326706,8601 & $7,6498 *$ \\
Fator B (genótipo) & 3 & 195774065,1433 & 65258021,7144 & $1,6734 \mathrm{~ns}$ \\
fator A x B & 3 & 126606362,2455 & 42202120,7485 & $1,0822 \mathrm{~ns}$ \\
tratamentos & 7 & 620707134,2488 & 88672447,7498 & \\
blocos & 3 & 172245082,0118 & 57415027,3373 & $1,4723 \mathrm{~ns}$ \\
resíduo & 21 & 818952629,2114 & 38997744,2482 & \\
\hline
\end{tabular}

Desvio padrão: 6244,8174. Erro padrão da média: 3122,4087. Média geral: 7601,2369. Coeficiente de variação: 82,1553. * Significativo a 5\%. ** Significativo a $1 \%$.

Tabela 61. Teste de Tukey referente ao comprimento radicular (mm) total. Experimento V. Fator (dose de P)

\begin{tabular}{cc}
\hline Tratamento & Média \\
\hline 1 & 10654,5481 a \\
2 & 4547,9256 b \\
\hline
\end{tabular}


Tabela 62. Análise de variância referente à fitomassa seca total (g.planta ${ }^{-1}$ ) do genótipo G57. Experimento V

\begin{tabular}{ccccc}
\hline Causas da variação & G.L. & S.Q. & Q.M. & F \\
\hline Fator A (dose de P) & 2 & 544,8308 & 272,4154 & $0,9923 \mathrm{~ns}$ \\
Fator B (genótipo) & 1 & 868,2051 & 868,2051 & $3,1626 \mathrm{~ns}$ \\
fator A x B & 2 & 320,9323 & 160,4662 & $0,5845 \mathrm{~ns}$ \\
tratamentos & 5 & 1733,9682 & 346,7936 & \\
blocos & 3 & 523,9669 & 174,6556 & $0,6362 \mathrm{~ns}$ \\
resíduo & 15 & 4117,7895 & 274,5193 & \\
\hline
\end{tabular}

Desvio padrão: 16,5686. Erro padrão da média: 8,2843. Média geral: 43,2846. Coeficiente de variação: 38,2783. * Significativo a $5 \%$. ** Significativo a $1 \%$.

Tabela 63. Análise de variância referente ao número de raízes adventícias dos genótipos G6, G11, G21 e G57 aos 28 DAE. Experimento V

\begin{tabular}{ccccc}
\hline Causas da variação & G.L. & S.Q. & Q.M. & F \\
\hline Fator A (dose de P) & 1 & 21,1250 & 21,1250 & $0,4109 \mathrm{~ns}$ \\
Fator B (genótipo) & 3 & 1291,7500 & 430,5833 & $8,3744 * *$ \\
fator A x B & 3 & 100,6250 & 33,5417 & $0,6524 \mathrm{~ns}$ \\
tratamentos & 7 & 1413,5000 & 201,9286 & \\
blocos & 3 & 124,7500 & 41,5833 & $0,8088 \mathrm{~ns}$ \\
resíduo & 21 & 1079,7500 & 51,4167 & \\
\hline
\end{tabular}

Desvio padrão: 7,1705. Erro padrão da média: 3,5853. Média geral: 18,5000. Coeficiente de variação: 38,7597. * Significativo a $5 \%$. ${ }^{* *}$ Significativo a $1 \%$.

Tabela 64. Teste de Tukey referente à número de raízes adventícias dos genótipos G6, G11, G21 e G57 aos 28 DAE. Experimento V. Fator B (genótipo)

\begin{tabular}{cc}
\hline Tratamento & Média \\
\hline 3 & 26,3750 a \\
1 & $22,8750 \mathrm{ab}$ \\
4 & $14,0000 \mathrm{bc}$ \\
2 & $10,7500 \mathrm{c}$ \\
\hline
\end{tabular}


Tabela 65. Análise de variância referente à fitomassa seca de parte aérea (g.planta ${ }^{-1}$ ) do genótipo Pérola. Experimento VI

\begin{tabular}{ccccc}
\hline Causas da variação & G.L. & S.Q. & Q.M. & F \\
\hline blocos & 3 & 28,4195 & 9,4732 & $3,3900 *$ \\
tratamentos (P) & 5 & 553,5078 & 110,7016 & $39,6000 * *$ \\
resíduo & 15 & 41,9315 & 2,7954 & \\
total & 23 & 623,8588 & &
\end{tabular}

Desvio padrão: 1,6720. Erro padrão da média: 0,8360. Média geral: 10,6142. Coeficiente de variação: 15,7500. * Significativo a $5 \%$. ** Significativo a $1 \%$.

Tabela 66. Teste de Tukey referente à fitomassa seca de parte aérea (g.planta ${ }^{-1}$ ) do genótipo Pérola. Experimento VI

\begin{tabular}{cc}
\hline Tratamento (P) & Média \\
\hline 6 & $15,9750 \mathrm{a}$ \\
5 & $12,6750 \mathrm{ab}$ \\
1 & $11,9750 \mathrm{~b}$ \\
3 & $11,4250 \mathrm{~b}$ \\
4 & $11,1500 \mathrm{~b}$ \\
2 & $0,4853 \mathrm{c}$
\end{tabular}

DMS(TUKEY) $=3,8455$

Tabela 67. Análise de variância referente ao número de folhas compostas do genótipo pérola. Experimento VI

\begin{tabular}{ccccc}
\hline Causas da variação & G.L. & S.Q. & Q.M. & F \\
\hline blocos & 3 & 15,00 & 5,00 & $0,81 \mathrm{~ns}$ \\
tratamentos & 5 & 526,00 & 105,20 & $16,97 * *$ \\
resíduo & 15 & 93,00 & 6,20 & \\
total & 23 & 634,00 & & \\
\hline
\end{tabular}

Desvio padrão: 2,490. Erro padrão da média: 1,245. Média geral: 14,500. Coeficiente de variação: 17,170. * Significativo a $5 \%$. ** Significativo a $1 \%$. 
Tabela 68. Teste de Tukey referente ao número de folhas compostas do genótipo pérola. Experimento VI

\begin{tabular}{cc}
\hline Tratamento & Média \\
\hline 6 & $18,00 \mathrm{a}$ \\
1 & $17,25 \mathrm{a}$ \\
3 & $16,75 \mathrm{a}$ \\
4 & $15,50 \mathrm{a}$ \\
5 & $15,25 \mathrm{a}$ \\
2 & $4,25 \mathrm{~b}$ \\
\hline
\end{tabular}

DMS(TUKEY) $=5,727$

Tabela 69. Análise de variância referente ao número de raízes adventícias do genótipo pérola.

Experimento VI

\begin{tabular}{ccccc}
\hline Causas da variação & G.L. & S.Q. & Q.M. & F \\
\hline blocos & 3 & 83,6667 & 27,8889 & $1,30 \mathrm{~ns}$ \\
tratamentos & 5 & 251,3333 & 50,2667 & $2,34 \mathrm{~ns}$ \\
resíduo & 15 & 322,3333 & 21,4889 & \\
total & 23 & 657,3333 & &
\end{tabular}

Desvio padrão: 4,6356. Erro padrão da média: 2,3178. Média geral: 10,8333. Coeficiente de variação: 42,7900. * Significativo a $5 \%$. ** Significativo a $1 \%$.

Tabela 70. Análise de variância referente à produção de grãos por planta. Experimento VI

\begin{tabular}{ccccc}
\hline Causas da variação & G.L. & S.Q. & Q.M. & F \\
\hline fósforo & 5 & 1419,6750 & 283,9350 & $3,6506^{*}$ \\
resíduo & 26 & 2022,2000 & 77,7769 & \\
total & 31 & 3441,8750 & 111,0282 & \\
\hline
\end{tabular}

Média geral: 14,5625. Coeficiente de variação: 60,560. * Significativo a 5\%. ** Significativo a 1\%. NS: Não Significativa 
Tabela 71. Análise de variância referente à área foliar aos 21 dias após a emergência. Experimento

\begin{tabular}{ccccc} 
VI & & & \\
\hline Causas da variação & G.L. & S.Q. & Q.M. & F \\
\hline blocos & 3 & 1463920,9911 & 487973,6637 & $4,11^{*}$ \\
tratamentos & 5 & 14122327,4181 & 2824465,4836 & $23,80 * *$ \\
resíduo & 15 & 1780192,4790 & 118679,4986 & \\
total & 23 & 17366440,8883 & &
\end{tabular}

Desvio padrão: 344,4989. Erro padrão da média: 172,2495. Média geral: 1755,5488. Coeficiente de variação: 19,62. * Significativo a $5 \%$. ** Significativo a $1 \%$

Tabela 72. Teste de Tukey referente à área foliar aos 21 dias após a emergência. Experimento VI

\begin{tabular}{cc}
\hline Tratamento & Média \\
\hline 6 & $2524,4600 \mathrm{a}$ \\
3 & $2110,9225 \mathrm{a}$ \\
5 & $2102,2025 \mathrm{a}$ \\
1 & $1934,8000 \mathrm{a}$ \\
4 & $1736,4325 \mathrm{a}$ \\
2 & $124,4750 \mathrm{~b}$ \\
\hline
\end{tabular}

DMS(TUKEY): 792,3475

Tabela 73. Teste de Tukey referente ao número de grãos por planta. Experimento VI

\begin{tabular}{cc}
\hline Tratamento & Média \\
\hline CP & $24,3333 \mathrm{a}$ \\
S & $22,6000 \mathrm{~b}$ \\
SSF & $16,6666 \mathrm{c}$ \\
SS & $15,1666 \mathrm{~d}$ \\
SF & $11,1666 \mathrm{e}$ \\
SP & $3,6666 \mathrm{f}$ \\
\hline
\end{tabular}


Tabela 74. Análise de variância referente à fitomassa seca de grãos. Experimento VI

\begin{tabular}{|c|c|c|c|c|}
\hline Causas da variação & G.L. & S.Q. & Q.M. & F \\
\hline fósforo & 5 & 63,7131 & 12,7426 & $2,8876^{*}$ \\
\hline resíduo & 26 & 114,7329 & 4,4128 & \\
\hline total & 31 & 178,4460 & 5,7563 & \\
\hline \multicolumn{5}{|c|}{$\begin{array}{l}\text { Média geral: } 2,7756 \text {. Coeficiente de variação: } 75,683 .{ }^{*} \text { Significativo a } 5 \% .{ }^{* *} \text { Significativo a } 1 \% \text {. NS: Não } \\
\text { Significativa }\end{array}$} \\
\hline \multicolumn{5}{|c|}{ Tabela 75. Teste de Tukey referente à fitomassa seca de grãos. Experimento VI } \\
\hline \multicolumn{2}{|c|}{ Tratamento } & \multicolumn{3}{|c|}{ Média } \\
\hline \multicolumn{2}{|c|}{$\mathrm{S}$} & \multicolumn{3}{|c|}{$4,6200 \mathrm{a}$} \\
\hline \multicolumn{2}{|c|}{$\mathrm{CP}$} & \multicolumn{3}{|c|}{ 4,3067 b } \\
\hline \multicolumn{2}{|c|}{ SSF } & \multicolumn{3}{|c|}{ 3,3333 c } \\
\hline \multicolumn{2}{|c|}{ SS } & \multicolumn{3}{|c|}{$3,1000 \mathrm{~d}$} \\
\hline \multicolumn{2}{|c|}{$\mathrm{SF}$} & \multicolumn{3}{|c|}{1,9333 e } \\
\hline \multicolumn{2}{|c|}{ SP } & \multicolumn{3}{|c|}{$0,4333 \mathrm{f}$} \\
\hline
\end{tabular}

Tabela 76. Análise de variância referente ao ciclo. Experimento VI

\begin{tabular}{ccccc}
\hline Causas da variação & G.L. & S.Q. & Q.M. & F \\
\hline fósforo & 5 & 1577,1354 & 315,4271 & $3,6672^{*}$ \\
resíduo & 26 & 2236,3333 & 86,0128 & \\
total & 31 & 3813,4687 & 123,0151 &
\end{tabular}

Média geral: 105,7812. Coeficiente de variação: 8,767. * Significativo a 5\%. ** Significativo a 1\%. NS: Não Significativa 
Tabela 77. Teste de Tukey referente ao ciclo. Experimento VI

\begin{tabular}{cc}
\hline Tratamento & Média \\
\hline SSF & $113,0000 \mathrm{a}$ \\
SS & $112,1666 \mathrm{~b}$ \\
SF & $107,5000 \mathrm{c}$ \\
CP & $107,3333 \mathrm{~d}$ \\
SP & $100,3333 \mathrm{e}$ \\
S & $93,0000 \mathrm{f}$ \\
\hline
\end{tabular}

Tabela 78. Análise de variância referente ao número vagens por planta. Experimento VI

\begin{tabular}{ccccc}
\hline Causas da variação & G.L. & S.Q. & Q.M. & F \\
\hline fósforo & 5 & 254,8666 & 50,9733 & $3,2275^{*}$ \\
resíduo & 26 & 410,6333 & 15,7936 & \\
total & 31 & 665,5000 & 21,4674 & \\
\hline
\end{tabular}

Média geral: 6,1250. Coeficiente de variação: 64,8840. * Significativo a 5\%. ** Significativo a 1\%. NS: Não Significativa

Tabela 79. Teste de Tukey referente ao número de vagens por planta. Experimento VI

\begin{tabular}{cc}
\hline Tratamento & Média \\
\hline S & $10,8000 \mathrm{a}$ \\
CP & $9,0000 \mathrm{~b}$ \\
SSF & $6,3333 \mathrm{c}$ \\
SF & $6,1666 \mathrm{~d}$ \\
SS & $4,8333 \mathrm{e}$ \\
SP & $1,8333 \mathrm{f}$ \\
\hline
\end{tabular}


Tabela 80. Análise de variância referente à fitomassa seca relativa de raiz (\%). Experimento VI

\begin{tabular}{ccccc}
\hline Causas da variação & G.L & S.Q & Q.M & F \\
\hline blocos & 3 & 343,8440 & 114,6147 & $0,5700 \mathrm{~ns}$ \\
tratamentos & 5 & 5030,3717 & 1006,0743 & $4,9800^{* *}$ \\
resíduo & 15 & 3028,5700 & 201,9047 & \\
total & 23 & 8402,7857 & 365,3385 & \\
\hline
\end{tabular}

Desvio padrão: 14,2093. Erro padrão da média: 7,1047. Média geral:.62,7796 Coeficiente de variação: 22,63. * Significativo a 5\%. ** Significativo a 1\%. NS: Não Significativo

Tabela 81. Teste de Tukey referente à fitomassa seca relativa de raiz (\%). Experimento VI

\begin{tabular}{cc}
\hline Tratamento & Média \\
\hline 4 & $84,9750 \mathrm{a}$ \\
1 & $74,1275 \mathrm{ab}$ \\
6 & $68,3475 \mathrm{ab}$ \\
2 & $56,7125 \mathrm{ab}$ \\
5 & $49,6050 \mathrm{~b}$ \\
\end{tabular}

DMS(TUKEY) $=32,6814$

Tabela 82. Análise de variância referente à relação entre a fitomassa seca de parte aérea e de raiz (\%). Experimento VI

\begin{tabular}{ccccc}
\hline Causas da variação & G.L & S.Q & Q.M & F \\
\hline blocos & 3 & 0,0003 & 0,0001 & $0,24 \mathrm{~ns}$ \\
tratamentos & 5 & 0,4178 & 0,0836 & $233,3500^{* *}$ \\
resíduo & 15 & 0,0054 & 0,0004 & \\
total & 23 & 0,4234 & 0,0184 & \\
\hline
\end{tabular}

Desvio padrão: 0,0189. Erro padrão da média: 0,0095. Média geral: 0,1409. Coeficiente de variação: 13,43. * Significativo a 5\%. ** Significativo a 1\%. NS: Não Significativa. 
Tabela 83. Teste de Tukey referente à relação entre a fitomassa seca de parte aérea e de raiz (\%). Experimento VI

\begin{tabular}{cc}
\hline Tratamento & Média \\
\hline 2 & $0,4333 \mathrm{a}$ \\
1 & $0,1109 \mathrm{~b}$ \\
5 & $0,0937 \mathrm{bc}$ \\
6 & $0,0799 \mathrm{bc}$ \\
4 & $0,0751 \mathrm{bc}$ \\
3 & $0,0526 \mathrm{c}$ \\
\hline
\end{tabular}

DMS(TUKEY) $=0,0435$

Tabela 84. Análise de variância referente à área radicular $\left(\mathrm{mm}^{2}\right)$ do genótipo pérola. Experimento VI

\begin{tabular}{|c|c|c|c|c|}
\hline Causas da variação & G.L. & S.Q. & Q.M. & $\mathrm{F}$ \\
\hline blocos & 3 & 920336893,2946 & 306778964,4315 & $0,87 \mathrm{~ns}$ \\
\hline tratamentos & 5 & --- & --- & 14,77 ** \\
\hline resíduo & 15 & --- & 354033406,1042 & \\
\hline total & 23 & --- & & \\
\hline \multicolumn{5}{|c|}{$\begin{array}{l}\text { Desvio padrão: } 18815,7755 \text {. Erro padrão da média: 9407,8877. Média geral: 52907,9708. Coeficiente de variação: } \\
\text { 35,56. * Significativo a 5\%. ** Significativo a 1\%. }\end{array}$} \\
\hline \multicolumn{5}{|c|}{ Tabela 85. Teste de Tukey referente área radicular $\left(\mathrm{mm}^{2}\right)$ do genótipo pérola. Experimento VI } \\
\hline \multicolumn{2}{|c|}{ Tratamento } & \multicolumn{3}{|c|}{ Média } \\
\hline \multicolumn{2}{|c|}{1} & \multicolumn{3}{|c|}{$---a$} \\
\hline \multicolumn{2}{|c|}{4} & \multicolumn{3}{|c|}{$87015,1000 a b$} \\
\hline \multicolumn{2}{|c|}{5} & \multicolumn{3}{|c|}{56572,6500 bc } \\
\hline \multicolumn{2}{|c|}{6} & \multicolumn{3}{|c|}{$43225,9500 \mathrm{~cd}$} \\
\hline \multicolumn{2}{|c|}{3} & \multicolumn{3}{|c|}{$19614,4750 \mathrm{~cd}$} \\
\hline \multicolumn{2}{|c|}{2} & \multicolumn{3}{|c|}{$9986,3000 \mathrm{~d}$} \\
\hline
\end{tabular}

